\title{
Regulation of ROS Metabolism in Plants under Environmental Stress: A Review of Recent Experimental Evidence
}

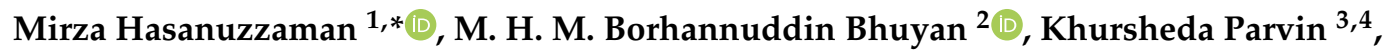 \\ Tasnim Farha Bhuiyan ${ }^{5}$, Taufika Islam Anee ${ }^{1}\left(\mathbb{D}\right.$, Kamrun Nahar $^{5}$, Md. Shahadat Hossen ${ }^{6}(\mathbb{0}$, \\ Faisal Zulfiqar ${ }^{7}{ }^{\circledR}$, Md. Mahabub Alam ${ }^{1}$ and Masayuki Fujita ${ }^{3, *}$ \\ 1 Department of Agronomy, Faculty of Agriculture, Sher-e-Bangla Agricultural University, \\ Sher-e-Bangla Nagar, Dhaka 1207, Bangladesh; taufiqaislam@gmail.com (T.I.A.); \\ shamim1983@yahoo.com (M.M.A.) \\ 2 Citrus Research Station, Bangladesh Agricultural Research Institute, Jaintapur, Sylhet 3156, Bangladesh; \\ razon_sau@yahoo.com \\ 3 Laboratory of Plant Stress Responses, Faculty of Agriculture, Kagawa University, Miki-cho, Kita-Gun, \\ Kagawa 761-0795, Japan; hirasau@gmail.com \\ 4 Department of Horticulture, Faculty of Agriculture, Sher-e-Bangla Agricultural University, \\ Sher-e-Bangla Nagar, Dhaka 1207, Bangladesh \\ 5 Department of Agricultural Botany, Faculty of Agriculture, Sher-e-Bangla Agricultural University, \\ Sher-e-Bangla Nagar, Dhaka 1207, Bangladesh; farhatasnim28@gmail.com (T.F.B.); \\ knahar84@yahoo.com (K.N.) \\ 6 Independent Researcher, Dhaka 1207, Bangladesh; shahadat.hossen32@yahoo.com \\ 7 Institute of Horticultural Sciences, Faculty of Agriculture, University of Agriculture, \\ Faisalabad 38000, Pakistan; ch.faisal.zulfiqar@gmail.com \\ * Correspondence: mhzsauag@yahoo.com (M.H.); fujita@ag.kagawa-u.ac.jp (M.F.)
}

Received: 1 September 2020; Accepted: 17 November 2020; Published: 18 November 2020

\begin{abstract}
Various environmental stresses singly or in combination generate excess amounts of reactive oxygen species (ROS), leading to oxidative stress and impaired redox homeostasis. Generation of ROS is the obvious outcome of abiotic stresses and is gaining importance not only for their ubiquitous generation and subsequent damaging effects in plants but also for their diversified roles in signaling cascade, affecting other biomolecules, hormones concerning growth, development, or regulation of stress tolerance. Therefore, a good balance between ROS generation and the antioxidant defense system protects photosynthetic machinery, maintains membrane integrity, and prevents damage to nucleic acids and proteins. Notably, the antioxidant defense system not only scavenges ROS but also regulates the ROS titer for signaling. A glut of studies have been executed over the last few decades to discover the pattern of ROS generation and ROS scavenging. Reports suggested a sharp threshold level of ROS for being beneficial or toxic, depending on the plant species, their growth stages, types of abiotic stresses, stress intensity, and duration. Approaches towards enhancing the antioxidant defense in plants is one of the vital areas of research for plant biologists. Therefore, in this review, we accumulated and discussed the physicochemical basis of ROS production, cellular compartment-specific ROS generation pathways, and their possible distressing effects. Moreover, the function of the antioxidant defense system for detoxification and homeostasis of ROS for maximizing defense is also discussed in light of the latest research endeavors and experimental evidence.
\end{abstract}

Keywords: abiotic stress; reactive oxygen species; oxidative stress; antioxidant defense system; abiotic stress tolerance 


\section{Introduction}

Ensuring food security is one of the most defined concerns and high-priority areas among plant scientists [1]. Meanwhile, agricultural productivity is under immense pressure in the scenario of stringent climate change and an ever-increasing affluent population [2]. Under such a scenario, it is imperative to understand the coordinated processes of plant metabolism to improve crop productivity. Due to changing climate, abiotic stresses become one of the most critical factors that severely reduce crop productivity. For instance, environmental stresses lead to altered nutrient acquisition and biosynthetic capacity that can inhibit plant growth. Furthermore, under abiotic stresses, modification of signaling pathways, expression of genes, proteins, and post-translation may occur, which activates numerous stress-responsive transcription factors to adapt the downstream responses needed to support an effective defense to specific abiotic stress challenges [3,4].

The existence of aerobic organisms, such as plants, depends on oxygen for energy generation systems. Moreover, plants also produce $\mathrm{O}_{2}$ during the photosynthesis. Molecular oxygen could be excited, forming reactive oxygen species (ROS). This ROS includes singlet oxygen $\left({ }^{1} \mathrm{O}_{2}\right)$, superoxide radical $\left(\mathrm{O}_{2}{ }^{\bullet-}\right)$, hydroxyl radical $\left({ }^{\bullet} \mathrm{OH}\right)$, and hydrogen peroxide $\left(\mathrm{H}_{2} \mathrm{O}_{2}\right)[5,6]$. The generation of toxic ROS as a by-product occurs in various cellular sites, such as mitochondria, chloroplast, peroxisome, and apoplast [7]. Under normal conditions, a balance exists between the production and scavenging of ROS by the coordinated action of antioxidant defense system components within the plants [8]. The generation of ROS at a lower level during normal growing conditions takes part in crucial intra- and inter-cellular signaling processes for inducing a positive response in antioxidant defense systems and the biological processes such as cellular proliferation, differentiation, or stress adaptation mechanisms [5].

On the other hand, disproportionation between ROS generation and scavenging leads to oxidative damage under stress conditions hampering normal cellular function, damaging biomolecules such as carbohydrates, lipids, proteins, and DNA, and finally causes cell death [8]. Thus, a stringent regulation between ROS production and scavenging that aids a plant in utilizing ROS as a defense molecule under stress conditions is crucial [9]. To regulate cell redox homeostasis under a stressful situation, plants utilize a multifaceted and strong antioxidant defense system where non-enzymatic and enzymatic components perform their function in sensing and elimination/detoxification of excess ROS [10]. Therefore, different plants have varied capacities to tolerate oxidative stress that depends on the ability of their antioxidant machinery. Moreover, ROS induced redox signals regulate various vital processes of the cellular environment. For example, ROS-induced redox signaling in plants induces programs of gene expression and aids in maintaining cellular redox homeostasis.

Moreover, the progression of different basic biological processes related to cellular differentiation, proliferation, and cell death are also attributed to ROS-induced redox signaling. Previously, it was thought that these biological processes are attributed to ROS-induced oxidative damage; but recent reports suggest that these processes are triggered by the ROS activating programmed cell death pathway [11]. Henceforth, it is evident that ROS-induced redox signaling plays a vital function in the various physiological responses.

Therefore, this review provides an in-depth look at recent findings related to ROS metabolism domains in plants such as ROS production sites, antioxidant networks, and their synergistic and counter effects under environmental stresses with a particular focus on oxidative stress.

\section{Types of Reactive Oxygen Species}

Partially reduced or activated molecular $\mathrm{O}_{2}$ or the primary product or by-product of $\mathrm{O}_{2}$-containing molecules showing higher reactivity than atmospheric $\mathrm{O}_{2}$ are ROS [12,13]. The transfer of energy or electrons produces ROS from $\mathrm{O}_{2}$ molecules; the most common cellular $\mathrm{ROS}$ are $\mathrm{H}_{2} \mathrm{O}_{2}, \mathrm{O}_{2}{ }^{\bullet-}, \cdot \mathrm{OH}$, and ${ }^{1} \mathrm{O}_{2}$ in plants $[13,14]$.

Both free radical and non-radical ROS are produced in cells (Figure 1). Among them, $\mathrm{O}_{2}{ }^{\bullet-}$, $\mathrm{OH}^{\bullet}$, alkoxyl radical $\left(\mathrm{RO}^{\bullet}\right)$, and peroxyl radical $\left(\mathrm{ROO}^{\bullet}\right)$ are the free radicals, while $\mathrm{H}_{2} \mathrm{O}_{2}$ and ${ }^{1} \mathrm{O}_{2}$ are 
the non-radicals [15]. Some other non-radical ROS, such as hypochlorous acid ( $\mathrm{HOCl})$, and excited carbonyl (RO*), are also found in plants [16]. Moreover, some acidic compounds (hypochlorous acid, $\mathrm{HOCl}$; hypoiodous acid, $\mathrm{HOI}$; and hypobromous acid, $\mathrm{HOBr}$ ) and some radical compounds like carbonate $\left(\mathrm{CO}_{3}{ }^{\bullet-}\right)$ are also incorporated into ROS [17].

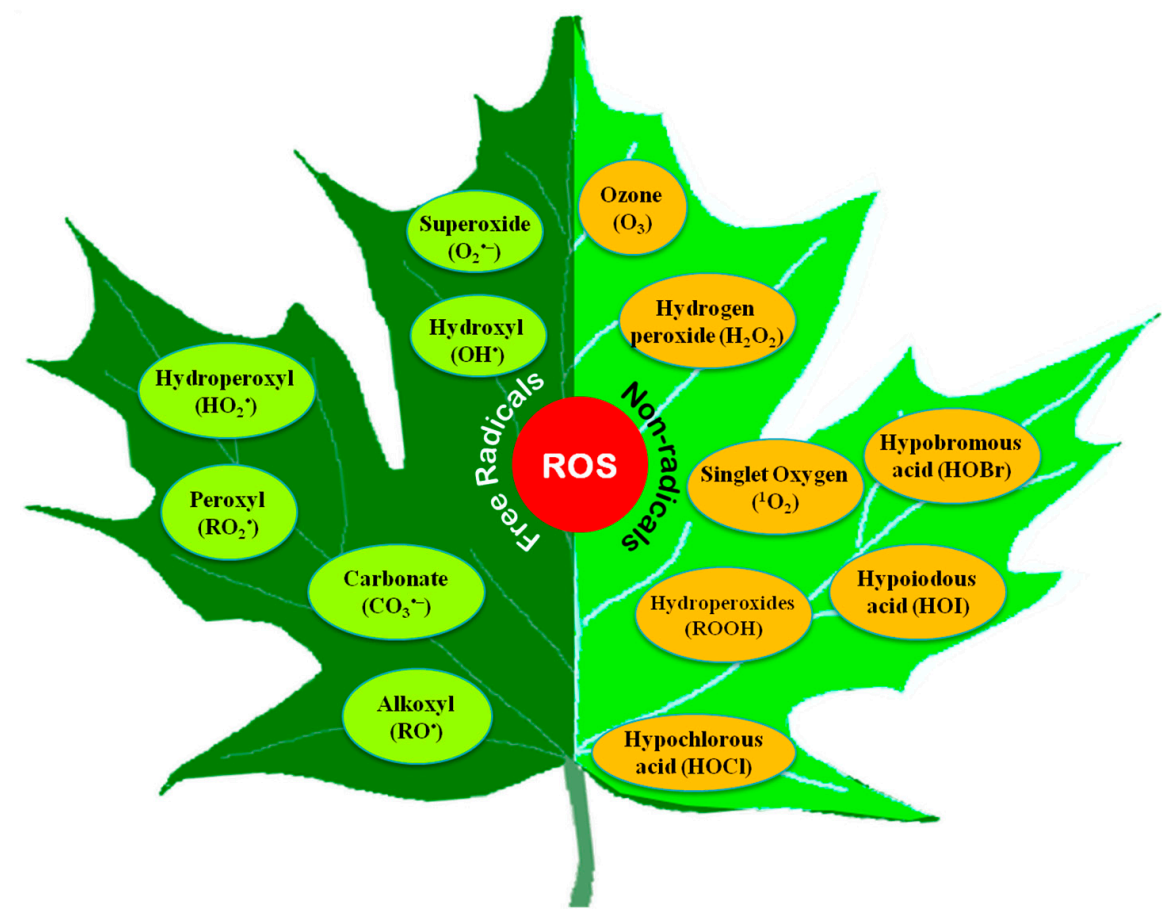

Figure 1. Different reactive oxygen species found in plants.

Besides, peroxyl radical $\left(\mathrm{LOO}^{\bullet}\right)$, alkoxyl radical $\left(\mathrm{LO}^{\bullet}\right)$, hydroperoxyl radical $\left(\mathrm{HO}_{2}{ }^{\bullet}\right)$, peroxynitrite $\left(\mathrm{HNO}_{3}{ }^{-}\right)$, ozone $\left(\mathrm{O}_{3}\right)$, and trichloromethyl peroxyl radical $\left(\mathrm{Cl}_{3} \mathrm{COO}^{\bullet}\right)$ could also be found in biological systems.

\section{Generation of ROS in Plant Cell}

Under stress conditions, the elevation of ROS relies on subcellular ROS metabolism and their transformation from one to another, which varies for different ROS types, cellular compartments, and even cell types (Figure 2). The diffusion distance of different ROS is also different; but it is to be noted that $\mathrm{H}_{2} \mathrm{O}_{2}$ may be one that is capable of moving from one cell compartment (or even cell) to another [18-20]. Therefore, cellular ROS accumulation also depends on the compartmental specific signaling effect and ROS detoxification [21,22].

To better understand ROS scavenging tactics, it is necessary to know the subcellular compartment-specific ROS generation. Different cell compartments have their specific ROS generation and detoxification capacity, being of vital importance for regulating ROS scavenging systems and keeping the ROS below the threshold level for protecting cellular components or initiating signaling cascade.

\subsection{Chloroplast}

The chloroplast is one of the leading ROS production sites in plants [23,24], where ROS generation, directly and indirectly, depends on the interaction of chlorophyll (chl) and light. Here, triplet chl and electron transport chain (ETC), specifically PSI and PSII, are the primary sources for ROS production [25-27]. In PSI, $\mathrm{O}_{2}{ }^{\bullet-}$ is produced by Mehler reaction and then superoxide dismutase (SOD) converts them into $\mathrm{H}_{2} \mathrm{O}_{2}$ [26]. In the presence of metal ions such as $\mathrm{Fe}^{2+}$, more highly reactive 
short-lived $\mathrm{HO}^{\bullet}$ are formed from $\mathrm{O}_{2}{ }^{\bullet-}$ and $\mathrm{H}_{2} \mathrm{O}_{2}$ [27,28]. Environmental stresses cause stomatal closure, and consequent lowering of $\mathrm{CO}_{2}$ level provokes the chloroplastic ROS production [29].

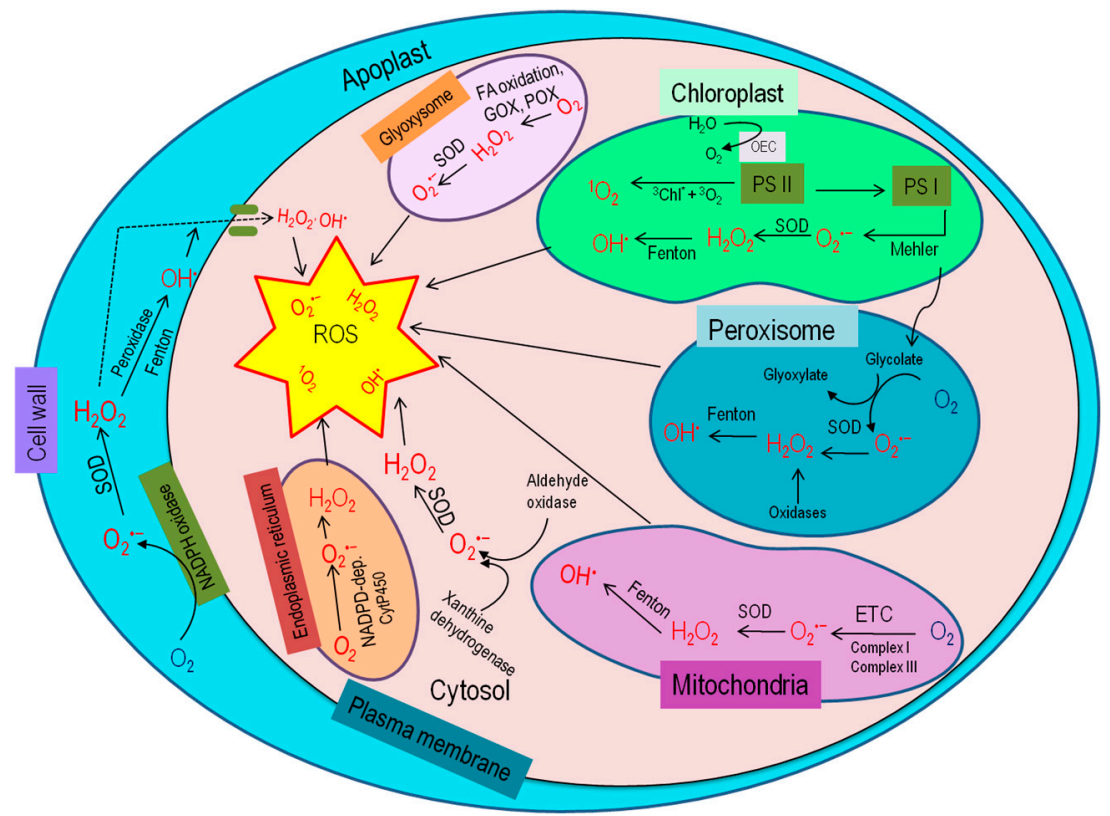

Figure 2. Site and generation of ROS within the plant cell [16].

\subsection{Peroxisome}

Abiotic stresses induce higher photorespiration in the peroxisome. Here, glycolate oxidase (GOX) is the crucial player for elevated ROS production [30]. In the peroxisome, $\mathrm{O}_{2}{ }^{\bullet-}$ can be produced at the organelle matrix by xanthine oxidase (XOD) and peroxisomal membrane NADPH oxidase [31]. Metalloenzymes, SODs, later dismutate $\mathrm{O}_{2}{ }^{\bullet-}$ into $\mathrm{H}_{2} \mathrm{O}_{2}$. Different types of SODs, including Cu-Zn-SOD and $\mathrm{Mn}-\mathrm{SOD}$, have been discovered in peroxisomes of various plant species [31]. Peroxisome is considered one of the major sites for $\mathrm{H}_{2} \mathrm{O}_{2}$ generation [31,32]. Besides, photorespiration GOX reaction, $\mathrm{O}_{2}{ }^{\bullet-}$ disproportionation, $\beta$-oxidation of fatty acids, flavin oxidase polyamine oxidase, sulfite oxidase, copper amine oxidase, and sarcosine oxidase activity are the prime metabolic processes through which $\mathrm{H}_{2} \mathrm{O}_{2}$ are produced in peroxisomes $[16,30,33]$.

\subsection{Mitochondria}

In the non-green plant organs, particularly in the root, mitochondria are the major ROS generation sites [26]. Mitochondrial ETC holds electrons with sufficient free energy, from which $0.2-2 \%$ of electrons transferred interact with $\mathrm{O}_{2}$ to produce ROS, and hence, apparently 1-2\% of $\mathrm{O}_{2}$ becomes partially reduced [23,24,34]. In such a case, complex I and III in the ETC of mitochondria are the two major sites for ROS production [35]. On abiotic stresses, excessive amounts of ROS are accumulated through electron leakage from both complexes I and III, and produce $\mathrm{O}_{2}{ }^{\bullet-}$, which is later catalyzed by Mn-SOD and $\mathrm{Cu}-\mathrm{Zn}-\mathrm{SOD}$ and produce $\mathrm{H}_{2} \mathrm{O}_{2}[27,36]$.

\subsection{Cell Wall}

Complex structures made by poly-saccharides, phenolics, and proteins in the plant cell walls are the active site for ROS production [37]. Stressed-plants become prone to growth reduction by differential cell wall growth, where ROS, along with peroxidase, triggers polymerization of glycoproteins and phenolic compounds to make cell walls rigid $[24,38,39]$. These cell wall-associated peroxidases catalyze $\mathrm{H}_{2} \mathrm{O}_{2}$ generation in the presence of NADH, where the NADH is solely provided from malate dehydrogenase [24]. Additionally, diamine oxidases cause ROS generation in the cell wall by 
reducing diamines or polyamines to quinine [40]. Under stress conditions, lipoxygenase (LOX)-induced polyunsaturated fatty acid (PUFA) hydroperoxidation is another potential source of ROS [41].

\subsection{Plasma Membrane}

In the plasma membrane, $\mathrm{O}_{2}{ }^{\bullet-}$ generation is mediated by NADPH oxidase and quinine reductase [42], where electron transportation from cytoplasmic NADPH is catalyzed by NADPH oxidase to form $\mathrm{O}_{2}{ }^{\bullet-}$, which is again converted into $\mathrm{H}_{2} \mathrm{O}_{2}$.

Reactive oxygen species are also produced in the endoplasmic reticulum, glyoxysome, and cytosol [43]. In the endoplasmic reticulum, Cyt $\mathrm{P} 450$ produces $\mathrm{O}_{2}{ }^{\bullet-}$ as a by-product during reaction with an organic substrate to form a free radical intermediate (Cyt $\mathrm{P} 450-\mathrm{ROO}^{-}$), where NADPH is the electron donor [40]. In glyoxysome, both $\mathrm{O}_{2}{ }^{--}$and $\mathrm{H}_{2} \mathrm{O}_{2}$ are produced from the fatty acid oxidation by GOX and urate oxidase activities [44]. Moreover, both XOD and aldehyde oxidase (AO) are actively engaged in ROS production in the cytosol $[43,45]$.

\section{Outcome and Indicators of Oxidative Stress}

As the by-products of aerobic metabolism, ROS are found to generate naturally in plants. However, when exposed to a stressful environment, the over-generation of ROS disrupts the equilibrium between ROS accumulation and scavenging, causing oxidative damage of biomolecules that cause cellular damage and death $[16,46]$. Under oxidative stress, biomolecules like lipids, proteins, DNA, carbohydrates, polynucleic acids, et cetera, become reversibly or irreversibly modified (Figure 3).

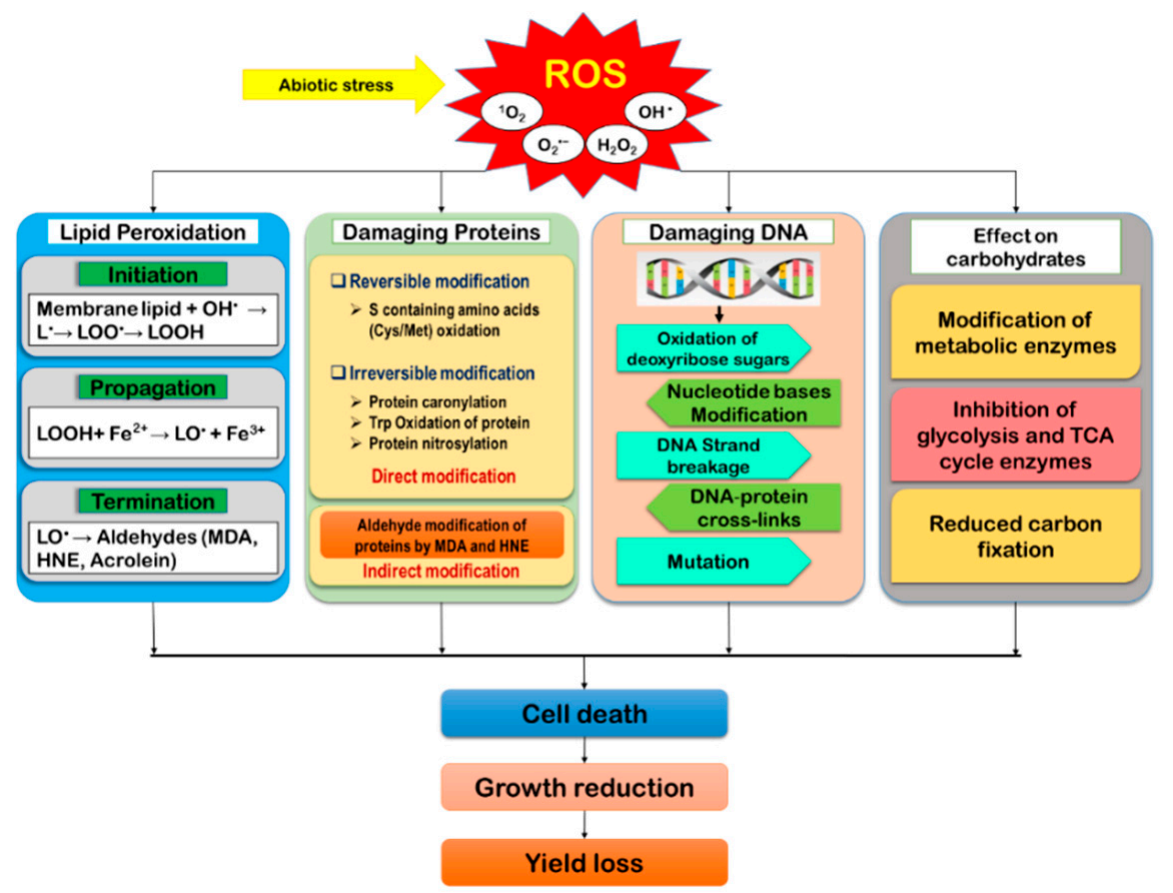

Figure 3. Reactive oxygen species-mediated cellular damage and its consequences in plants. (Lipid free radical, $\mathrm{L}^{\bullet}$; lipid peroxyl radical, $\mathrm{LOO}^{\bullet}$; lipid hydroperoxide, $\mathrm{LOOH}$; lipid alkoxyl radical, $\mathrm{LO}^{\bullet}$ ).

\subsection{Damage to Lipids}

Under oxidative stress, over-accumulated ROS causes lipid peroxidation (LPO), causing chain reactions and creates free radicals, resulting in lipid denaturation [47]. In the membrane phospholipids, the most susceptible sites for ROS attack are the carbon (C) atoms and the ester linkage between fatty acids and glycerol. Moreover, ${ }^{1} \mathrm{O}_{2}$ and $\mathrm{OH}^{\bullet}$ attack the plasma membrane polyunsaturated fatty acids (linoleic and linolenic acids) [48]. Lipid peroxidation is divided into three definite consecutive stages, including (i) initiation, (ii) propagation/progression, and (iii) termination. Of all three steps, initiation 
is the rate-limiting step. In this process, $\mathrm{H}^{+}$is subtracted from the methylene group $\left(-\mathrm{CH}_{2}\right)$, giving rise to a carbon-centered radical $-^{\bullet} \mathrm{CH}$ - or lipid-free radical $\left(\mathrm{L}^{\bullet}\right)$. Due to $\mathrm{H}^{+}$subtraction, the double bond in the fatty acid weakens, facilitating the $\mathrm{C}-\mathrm{H}$ bond. Thus, the lipids remain vulnerable to free radicals and peroxidation [49]. In the propagation stage, $\mathrm{L}^{\bullet}$ activates $\mathrm{O}_{2}$, generating the lipid peroxyl radical $\left(\mathrm{LOO}^{\bullet}\right)$, and the abstracting of a second $\mathrm{H}^{+}$from nearby fatty acid produces the lipid hydroperoxide $(\mathrm{LOOH})$ and causes another $\mathrm{L}^{\bullet}$ [50]. Subsequently, the $\mathrm{LOOH}$ is cleaved by the reduced transition metals like $\mathrm{Fe}^{2+}$ or $\mathrm{Cu}^{+}$, forming a highly reactive radical called the lipid alkoxyl (LO') and resulting in the formation of different aldehydes, alkanes, lipid epoxides, and so on. The termination of the LPO occurs through the formation of various lipid dimmers from lipids-derived radicals.

$$
\begin{gathered}
\left.\mathrm{L}-\mathrm{H}+\mathrm{OH}^{\bullet} \rightarrow \mathrm{L}^{\bullet} \text { (lipid radical }\right)+\mathrm{H}_{2} \mathrm{O} \\
\mathrm{L}^{\bullet}+\mathrm{O}_{2} \rightarrow \mathrm{LOO}^{\bullet} \text { (lipid peroxyl radical) } \\
\mathrm{LOO}^{\bullet}+\mathrm{L}-\mathrm{H} \rightarrow \mathrm{LOOH} \text { (lipid hydroperoxide) }+\mathrm{L}^{\bullet} \\
\mathrm{LOOH}+\mathrm{Fe}^{2+} \rightarrow \mathrm{LO}^{\bullet} \text { (lipid alkoxyl radical) }+\mathrm{Fe}^{3+}
\end{gathered}
$$

Singlet oxygen evolved in the PSII reaction center, further reacts with the lipid double bonds forming $\mathrm{LOOH}$ [49]. Moreover, ${ }^{1} \mathrm{O}_{2}$ can be produced from the reaction of two $\mathrm{LOO}^{\bullet}$ damaging membranes' fluidity, collapsing membrane function, and causing the oxidation and dysfunctioning of membrane proteins, receptors, and localized enzymes, respectively [51]. Furthermore, by damaging membranes, severe LPO collapses their barrier function; thus, the cellular organelles disintegrate. Besides, LPO causes oxidative malfunctions of proteins, DNA, and RNA together with forming some disrupted and altered aldehyde substances like malondialdehyde (MDA), acrolein, and 4-hydroxy-2-nonenal (HNE), which are the oxidative stress markers in plants [49,52].

\subsection{Damage to Cellular Proteins}

Reactive oxygen species or other by-products of oxidative stress alter the covalent bond and induce protein oxidation. Any proteinogenic amino acid can be oxidized by ROS, altering the metabolic, structural, transport, or regulatory activities of proteins. As a secondary effect, some lipid peroxidation products like hydroxynonenal and MDA can react with proteins that modify arginine (Arg), lysine (Lys), proline (Pro), threonine (Thr), and tryptophan (Trp) and result in proteolytic degradation. These proteinogenic amino acids give rise to free carbonyl groups and become more susceptible to proteolytic activity [49]. Essential plant protein complexes including PSI protein complex (PSI-A to PSI-O and LHCI (Lhca1, Lhca2, Lhca3, Lhca4)), D1 protein of PSII, ribulose-1,5-bisphosphate carboxylase/oxygenase (RuBisCo), and SOD require the presence of ${ }^{\bullet} \mathrm{OH}$ and ${ }^{1} \mathrm{O}_{2}$ for oxidative damages, where the study revealed that ${ }^{1} \mathrm{O}_{2}$ is specifically found to affect $\mathrm{D} 1$ protein; whereas, increased activity of catalytically-active transition metal $\left({ }^{\bullet} \mathrm{OH}\right)$ is required for the damages of the others [53]. Collectively, $\operatorname{ROS}\left({ }^{\circ} \mathrm{OH},{ }^{1} \mathrm{O}_{2}\right.$, and $\left.\mathrm{H}_{2} \mathrm{O}_{2}\right)$ result in the oxidation of side chain residues of amino acids, protein-protein cross-linkages formation, protein backbone oxidation, as well as protein fragmentation [48]. Reactive oxygen species $\left({ }^{\bullet} \mathrm{OH},{ }^{1} \mathrm{O}_{2}\right)$ mainly target the proteins having sulfur-containing amino acids and thiol groups. The cysteine (Cys) and methionine (Met) modified residues containing thiol and sulfur groups are inevitably attacked by ${ }^{\bullet} \mathrm{OH}$ and ${ }^{1} \mathrm{O}_{2}$. Oxidative damages of proteins are mostly irreversible except those with S-containing amino acids (Met and Cys). The ${ }^{\bullet} \mathrm{OH}$ and ${ }^{1} \mathrm{O}_{2}$ form oxidized derivatives of amino acids sequentially (cysteine $\rightarrow$ cystine $\rightarrow$ cysteine sulfenic acid $\rightarrow$ cysteine sulfinic acid $\rightarrow$ cysteic acid) $[52,54]$. Therefore, disulfide bond formation, Cys oxidation, nitrosylation, glutathionylation, and sulfhydration result from redox modification of proteins. Furthermore, Kale et al. [55] proposed that, the formation of $\mathrm{HO}^{\bullet}$ at $\mathrm{Mn}_{4} \mathrm{O}_{5}$ Ca cluster and the nonheme iron of PSII resulted in the oxidation of specific amino acid residues of the proteins (D1, D2). Besides, oxidative modification of D1: ${ }^{130} \mathrm{E}$ and D2: ${ }^{246} \mathrm{M}$ residues were also evident by the formation of $\mathrm{O}_{2}{ }^{\bullet-}$ (by reducing $\mathrm{O}_{2}$ ). Again, several native amino acid residues were found to be oxidized by ROS; for example, D1, D2, and CP43 subunits in 
the locality of the cluster $\mathrm{Mn}_{4} \mathrm{O}_{5} \mathrm{Ca}$, a peptide of the $\mathrm{D} 1$ protein $\left({ }^{130} \mathrm{E}-{ }^{136} \mathrm{R}\right)$, and some other oxidized amino residues in the location of PheoD1 and $\mathrm{Q}_{\mathrm{A}}$ were demonstrated in several studies [56-58].

\subsection{Damage to Nucleotides and DNA}

The main damaging factor for polynucleic acids are the $\bullet \mathrm{OH}$, which alters nucleotide bases (purine and pyrimidine) by abstracting $\mathrm{H}^{+}$from the $\mathrm{C}-\mathrm{H}$ bonds of 2-deoxyribose and methyl group, causing deoxyribose radical, hydroxyl methyl urea, thymine glycol, et cetera, and breaks the double-stranded DNA into single-strands. Damage to DNA due to oxidative stress has been reported by several researchers [59,60]. Furthermore, ROS also damages DNA nucleotide by oxidizing deoxyribose sugar, modifying nucleotide bases, abstracting nucleotides, and DNA protein cross-linking. As a consequence of base oxidation, some damaging products (8-hydroxyquinine, dehydro-2'-deoxyguanosine, etc.) are formed, which cause irreparable cross-links and those are very lethal to plant cells [61]. If these damages are not repaired before the next replication or transcription, DNA denaturation and unfolding are the obvious results [52]. Additionally, incorrect protein sequences are also found as important consequences. Damage of DNA affects plant growth and development, directly affecting various physiological processes; for example, abnormal synthesis of protein and damage of photosynthetic proteins, et cetera. It can also arrest transcription, signal transduction, replication errors, and whole genomic instability [20]. Besides, DNA bases are not always damaged by direct oxidation but also through the reactive intermediates (generated from ROS attack) reacting with the macromolecules. For instance, polyunsaturated fatty acid residues of membrane phospholipids are often attacked by oxygen radicals and are considered vital indirect oxidative damage. Malondialdehyde, acrolein, and crotonaldehyde are some reactive by-products of membrane LPO [62].

\subsection{Effect on Carbohydrates}

In plants, under oxidative stress, redox modification of glycolysis and TCA cycle enzymes are among the primary damaging responses. With an increased ROS level, pentose phosphate pathway enzymes, for example, glyceraldehyde 3-phosphate dehydrogenase and fructose-1,6-bisphosphate aldolase, are inhibited. To cope with the high ROS level, these inhibited enzymes in the pentose phosphate pathway increase the carbon flux (by increasing cycle metabolites, ribose 5-P, and ribulose 5-P intermediates) to produce necessary NADPH [63]. Besides, enzymes of the TCA cycle are severely affected during oxidative stresses, and also inhibit enzyme aconitase and accelerate citrate biosynthesis. Contrarily, citrate accumulation plays vital roles as an introducer of alternative oxidase ROS detoxification under stress [64]. Lehman et al. [63] also demonstrated that under oxidative stress, reduced glycolysis and metabolism of the TCA cycle and amino acid have resulted in the plant. In this study, C flow in Arabidopsis root was investigated, kinetic analysis of ${ }^{13} \mathrm{C}$-Glc showed a decreased labeling for citrate, isocitrate, fumarate, malate, succinate, and 2-oxoglutarate, which suggested an inhibited C flux throughout the TCA cycle.

\section{Oxidative Stress under Abiotic Stress}

\subsection{Drought}

Drought stress induces stomatal closure and reduces $\mathrm{CO}_{2}$ fixation in plant leaves. Consequently, this stress creates disequilibrium between light capturing and utilization; as a result, the photosynthetic rate is reduced. During drought, photochemistry of chloroplasts become altered, and an imbalance between the electron release and acceptance results in the increased generation of ROS from the excess light energy in the photosystems. In fact, the absorbed light energy that cannot go to $\mathrm{CO}_{2}$ fixation, produce ROS [16,46]. Drought stress-induced $\mathrm{H}_{2} \mathrm{O}_{2}$ generation directly results from photorespiration [32]. Additionally, under drought stress, if chloroplast are exposed to excess light energy, ferredoxin becomes highly reduced; the regeneration of $\mathrm{NADP}^{+}$is hindered, which interferes with the acceptance of electrons causing reduced ETC as well as greater electron 
leakage, which contribute in overproducing ROS [65-67]. Drought-induced major and obvious oxidative stress markers are LPO (MDA) and $\mathrm{H}_{2} \mathrm{O}_{2}$ accumulation causing the dysfunctioning of various cellular and physiological processes, including stomatal conductance, membrane functions, water-use efficiency, carboxylation efficiency, respiration, photosynthesis, transpiration, and so on [68]. Reports indicate increased MDA and $\mathrm{H}_{2} \mathrm{O}_{2}$ contents under drought stress in many plant species, for example, rapeseed, maize, soybean, alfalfa, chili, et cetera, which together with the other toxic ROS gives rise to oxidative damages (Table 1).

Performance of Vigna radiata L. plants were studied under drought stress ( $5 \%$ polyethylene glycol, PEG; 48 h), singly or together with high temperature (HT) stress and then compared with the control grown plants. Drought and HT either singly or in combination caused higher generation of ROS including free radicals and non-radicals $\left(\mathrm{H}_{2} \mathrm{O}_{2}\right.$ and $\left.\mathrm{O}_{2}{ }^{--}\right)$along with the enhanced activity of the oxidative enzyme (LOX) resulting in increased LPO indicated by higher MDA levels in $V$. radiata L., compared to the control [69]. Hasanuzzaman et al. [66,70] also documented increased MDA and $\mathrm{H}_{2} \mathrm{O}_{2}$ content in Brassica napus L. cv. Bina Sharisha-3 under drought stresses (10 and 20\% PEG), where the addition of PEG-6000 in the growth medium resulted in osmotic stress. Nahar et al. [71] found overgeneration of toxic free radicals $\mathrm{O}_{2}{ }^{\bullet-}$ with increased LPO and thiobarbituric acid reactive substances (TBARS) in Oryza sativa L. plants when subjected to drought (15 and 20\% PEG) for seven days. Sarker and Oba [72] revealed higher electrolyte leakage (EL) resulting from increasing the drought stress severity in Amaranthus tricolor plants. In another study, declined EL level by 11, 26, and $47 \%$ under mild to severe levels of drought stresses induced by 5,10 , and $15 \%$ PEG ( $3 \mathrm{w})$, respectively, were reported in Glycine max [73]. Triticum aestivum L. subjected to severe drought stress ( $70 \%$ FC, field capacity) showed maximum TBARS, EL, and $\mathrm{H}_{2} \mathrm{O}_{2}$ contents of 31,25 , and $38 \%$, respectively, compared to controls [74]. Hussain et al. [75] also demonstrated similar oxidative stress in drought-affected Zea mays L. when investigating the effects of drought stress (50\% FC, $15 \mathrm{~d}$ ) on two-hybrid maize varieties, and found an overproduction of toxic $\operatorname{ROS}\left(\mathrm{O}_{2}{ }^{\bullet-}, \mathrm{H}_{2} \mathrm{O}_{2}\right.$, and $\left.{ }^{\bullet} \mathrm{OH}\right)$ and enhanced accumulation of MDA leading to oxidative stress condition. While working with $O$. sativa $\mathrm{L}$. subsp. japonica. cv. Nipponbare; drought stress (20\% PEG) increased $\mathrm{O}_{2}{ }^{\bullet-}$ by $23 \%$, enhanced $\mathrm{H}_{2} \mathrm{O}_{2}$ content by 1.21 -fold, and increased MDA content by $16 \%$, compared to controls, which were liable for creating oxidative damage [76]. Interestingly, drought-induced higher oxidative stress intensities varied among the cultivars and tolerant lentil cultivar (PDL-2) accumulated less ROS and reduced oxidative damage and showed better performance, compared to the sensitive cultivar (JL-3) under drought stress [77]. From these reports, it is obvious that drought stress induces oxidative stress in plants via enhancing toxic ROS levels that are deleterious for vital processes in plants.

\subsection{Salinity}

Salinity restricts crop productivity, particularly in the arid and semi-arid regions as well as in coastal soils. Salinity poses osmotic stress, ion toxicity, genotoxicity, nutritional deficiency, as well as initiates overproduction of ROS, leading to oxidative stress [78]. Under salinity stress, the root tissues suffer the most, followed by mature and young leaves, which are the least affected. Both mild $(75 \mathrm{mM} \mathrm{NaCl})$ and severe $(150 \mathrm{mM} \mathrm{NaCl})$ doses of salinity caused the increase in $\mathrm{MDA}, \mathrm{H}_{2} \mathrm{O}_{2}$, and $\mathrm{EL}$ of roots and mature leaf pairs of maize plants, including higher damage severity found under severe stress [79]. Using comet assay, Saha et al. [59] studied the oxidative DNA damage of mung bean under salt stress. They observed salinity-induced enhanced damage of DNA in seven day old mung bean seedlings, which was correlated to oxidative stress. They also found accelerated ROS accumulation in a dose-dependent manner causing larger DNA damage. Salt tolerant T. aestivum cv. BARI Gom-28 showed higher $\mathrm{H}_{2} \mathrm{O}_{2}$ and MDA content by 230 and $61 \%$ where 41 and $90 \%$, respectively, were found in sensitive cultivars [80]. Although higher $\mathrm{H}_{2} \mathrm{O}_{2}$ was observed in tolerant plants along with lower cellular damage than sensitive plants and these higher $\mathrm{H}_{2} \mathrm{O}_{2}$ might be performing signaling roles. It can be suggested that salt-sensitive cultivars suffered more from oxidative stress. Two-fold higher ROS generation $\left(\mathrm{O}_{2}{ }^{\bullet-}\right.$ and $\left.\mathrm{H}_{2} \mathrm{O}_{2}\right)$ along with higher MDA and EL were observed in mung beans under 
$100 \mathrm{mM} \mathrm{NaCl}$ and thus depicted increased oxidative damage [47]. Salt stress caused two times higher ROS generation with elevated LPO and EL in rice roots [81]. Similarly, salinity-mediated elevation of oxidative stress markers including $\mathrm{O}_{2}{ }^{\bullet-}, \mathrm{H}_{2} \mathrm{O}_{2}, \mathrm{EL}$, and MDA by 157, 176, 158, and 94\%, respectively, observed in tomatoes [82]. From these reports, it is obvious that salinity causes oxidative stress which is lethal for vital processes in plants.

\subsection{Metals/Metalloids Toxicity}

Metals/metalloids toxicity interrupts not only morpho-physiological traits but also causes enhanced oxidative stress resulting from lack of balance between antioxidant defense system and ROS production [83-89]. El-Amier et al. [90] reported increased levels of $\mathrm{LPO}$ and $\mathrm{H}_{2} \mathrm{O}_{2}$ accumulation in Ni $(100 \mu \mathrm{M})$ stressed Pisum sativum L. seedlings. Such increments of oxidative stress indicators was even higher in the same crop with the same concentration of $\mathrm{Cd}$ as well. Meanwhile, $\mathrm{Cd}$ stress raised the MDA and $\mathrm{H}_{2} \mathrm{O}_{2}$ production in different crops including $V$. radiata L. [83], B. napus L. [85], B. juncea L. [89], A. thaliana [91], and Cucumis sativus [92] under different levels of stress. Apart from MDA and $\mathrm{H}_{2} \mathrm{O}_{2}$, the rate of $\mathrm{O}_{2}{ }^{\bullet-}$ production was also higher in $V$. radiata L. [83]. Another study demonstrated the oxidative damages under $\mathrm{Pb}$ stress conditions in wheat plants [86]. Nahar et al. [84] reported higher levels of $\mathrm{H}_{2} \mathrm{O}_{2}, \mathrm{O}_{2}{ }^{-}$, and MDA contents, and LOX activity by $83,110,97$ and $72 \%$, respectively, in $V$. radiata L. cv. BARI Mung-2 when exposed to Al stress $(0.5 \mathrm{mM})$ for $48 \mathrm{~h}$. B. juncea seedlings exposed to $\mathrm{Cr}$ stress $(0.15$ and $0.3 \mathrm{mM}, 5 \mathrm{~d})$ exhibited higher TBARS and $\mathrm{H}_{2} \mathrm{O}_{2}$ contents as well as LOX than that of the control plants [88]. Thus, it is clear that metals/metalloids toxicity increased oxidative stress as depicted by oxidative stress markers such as MDA and $\mathrm{H}_{2} \mathrm{O}_{2}$.

\subsection{High Temperature}

When plants are exposed to HT, heat inactivation occurs on both sides of the electron acceptor and donor in PSII. On the PSII electron donor side, heat inactivation is linked with the inhibition of oxygen-evolving complex (OEC) through removing the extrinsic proteins from their binding sites via the release of $\mathrm{Ca}^{2+}$ and $\mathrm{Mn}^{2+}$, which is required for $\mathrm{H}_{2} \mathrm{O}$ splitting [93-95]. On the PSII electron acceptor side, heat inactivation impaired the electron flow from $Q_{A}$ to $Q_{B}$ due to the increased redox potential of $\mathrm{Q}_{\mathrm{A}} / \mathrm{Q}_{\mathrm{A}}{ }^{\bullet-}$ [95]. This impairs electron flow, which can exert damaging effects on the PSII reaction centers, including D1 and D2 proteins; causing further damage to D1 protein generating ${ }^{1} \mathrm{O}_{2}$ on the PSII electron acceptor side [95]. On the electron donor side of PSII, due to incomplete oxidation of $\mathrm{H}_{2} \mathrm{O}, \mathrm{H}_{2} \mathrm{O}_{2}$ forms, after that it has been converted into ${ }^{\bullet} \mathrm{OH}$ radicals by Fenton reaction [95]. Heat inactivation also occurred due to the moderate temperature in spinach thylakoids causing LPO and damage to D1 and LHCII as well [96]. Moreover, it has been suggested that sink capacity declines due to the slowing down of carbon fixation, resulting in an increased excitation pressure in the chloroplasts. In PSII, this high excitation pressure causes photoinhibition [97]. High temperature also affects the reaction center of PSI resulting in photoinhibition, which is a rare case in nature due to the P700 oxidation system of the plant that can suppress the excessive excitation pressure of P700 [98]. Several studies reported that unlike PSII, PSI is not a limiting factor in the overall photosynthetic activity of plants $[93,99,100]$. High temperature $\left(35 / 32{ }^{\circ} \mathrm{C}\right.$ day/night) stress slowed down the electron flow to the PSII reaction center and reduced quantum efficiency $(\mathrm{Fv} / \mathrm{Fm})$ and down-regulated photochemistry of PSII of rice (cv. IR64 and Huanghuazhan) [101]. However, short-lived and unstable ${ }^{1} \mathrm{O}_{2}$ has a great impact on photosynthesis once it is formed. Moreover, due to instability and higher oxidation-reduction activity, $\mathrm{O}_{2}{ }^{\bullet-}$ is a vital precursor for various ROS products. In a study, 21-d-old purslane (Portulaca oleracea L.) seedlings were treated with $\mathrm{HT}\left(42{ }^{\circ} \mathrm{C}, 7 \mathrm{~d}\right)$ showed higher levels of $\mathrm{O}_{2}{ }^{\bullet-}$, EL, and MDA content by 2.4, 3.84 -fold, and $23 \%$, respectively, than that of controls [102].

Awasthi et al. [103] tested HT stress $\left(32 / 20^{\circ} \mathrm{C}\right.$ day/night, $\left.7 \mathrm{~d}\right)$ in heat-tolerant and heat-sensitive chickpea plants and observed 6.5-fold increased $\mathrm{H}_{2} \mathrm{O}_{2}$ content in leaves of sensitive genotypes than in tolerant ones (5.7-fold). In contrast, MDA content and EL increased by 2.9-6.2-fold and 1.2-1.8-fold in heat-tolerant and sensitive plants, respectively. Furthermore, $\operatorname{HT}\left(45 / 30 \pm 2{ }^{\circ} \mathrm{C}\right)$ at three reproductive 
phases of the cotton plant caused 0.78 times increased MDA content than controls, which affected the cell organelles [104]. Contrarily, Liu et al. [76] found no substantial change in the content of $\mathrm{O}_{2}{ }^{\bullet-}$ and MDA in rice seeds but $\mathrm{H}_{2} \mathrm{O}_{2}$ increased by 1.27 -fold under $\mathrm{HT}$ stress $\left(38^{\circ} \mathrm{C}, 5 \mathrm{~d}\right.$ ) compared to controls. From these reports, it is clear that HT stress causes oxidative stress as depicted by the oxidative stress markers.

\subsection{Low Temperature}

In several plant species, low temperature (LT) also increases ROS and induces oxidative stress. For example, Guo et al. [105] exposed two sweet sorghum inbred lines (Sorghum bicolor L. cv. M81-E and Roma) to LT $\left(10^{\circ} \mathrm{C} ; 0,12,24,36\right.$, and $\left.48 \mathrm{~h}\right)$ and observed that MDA content increased to a maximum in both M81-E and Roma by $266 \%$ after $48 \mathrm{~h}$ of LT stress. Zhang et al. [106] studied two rice cultivars, japonica (Nipponbare) and indica (93-11), under LT stress $\left(2 \pm 1^{\circ} \mathrm{C} ; 10,33,57 \mathrm{~h}\right)$, where a higher level of $\mathrm{H}_{2} \mathrm{O}_{2}$ at $33 \mathrm{~h}$ of stress imposition was reported in cv. Nipponbare, compared to cv. 93-11. A similar trend for $\mathrm{H}_{2} \mathrm{O}_{2}$ overgeneration was also reported by Diao et al. [107] and Ghanbari and Sayyari [108] in tomatoes under LT stress $\left(4^{\circ} \mathrm{C}, 24 \mathrm{~h}\right.$; and $3{ }^{\circ} \mathrm{C}, 6 \mathrm{~h}$ and $\left.6 \mathrm{~d}\right)$. In another study, LT stressed $\left(12{ }^{\circ} \mathrm{C}\right.$, $6 \mathrm{~d}$ ) rice seedlings showed a $180 \%$ increased MDA and $49 \% \mathrm{EL}$, compared to controls [109]. However, it was interestingly seen by Jan et al. [110] that MDA content increased by $16.79 \%$ after $24 \mathrm{~h}$, whereas it decreased by $12.21 \%$ after $48 \mathrm{~h}$ in tomato plants; where EL also showed a similar trend. To evaluate the LT tolerance correlation with the presence of oxidative stress markers in rice shoots and roots, Hsu and Hsu [111] experimented with eight Taiwan rice cultivars exposed to LT ( $15^{\circ} \mathrm{C}$ for $4 \mathrm{~d}$ ) in a programmable incubator. They observed that the higher growth rate of the LT treated cultivars had a higher level of $\mathrm{H}_{2} \mathrm{O}_{2}$ in their shoots than the roots. In comparison, the LT treated slow-growing cultivars had higher levels of $\mathrm{H}_{2} \mathrm{O}_{2}$ along with higher MDA and EL in their roots than the shoots that caused the interruption of the nutrient uptake from root to shoot. It suggested the presence of higher $\mathrm{H}_{2} \mathrm{O}_{2}$ content correlated positive growth in the shoots but negative in the roots during LT stress (Table 1).

\subsection{Waterlogging/Flooding}

In the natural ecosystem, sudden extreme climate change events like a flood can hamper the natural distribution of plants or even cause extinction [112,113]. Besides causing hypoxia; flooding or waterlogging (WL) may also result in anoxia, which hampers respiration and generates toxic compounds causing impaired metabolic processes [113-115]. Ceased growth and biomass production, disturbance in the light interception and root hydraulic conductivity, limitation of stomatal conductance and $\mathrm{CO}_{2}$ assimilation, reduced photosynthesis and respiration, and altered accumulation of the secondary metabolites are the main reasons for yield reduction [116]. Such impairments of metabolic processes result in ROS generation and oxidative damages under WL condition.

Studies have revealed flooding-induced increments of LPO, ROS overgeneration, and other oxidative damages in different crops. Some cereal crops, for example, Z. mays L., S. bicolor L., Hordeum vulgare L., et cetera, showed a remarkable increase in $\mathrm{LPO}$ and accumulation of $\mathrm{H}_{2} \mathrm{O}_{2}, \mathrm{O}_{2}{ }^{\bullet-}$, and ${ }^{\bullet} \mathrm{OH}$ under different durations of WL condition [117-119]. Li et al. [117] chose eighteen maize genotypes to evaluate the WL (2 d)-induced changes in LPO. They observed that MDA content increased in only in four genotypes, compared to control plants, but declined in other genotypes, which might be due to the scavenging of ROS by antioxidant enzymes. Two barley (WL sensitive cv. TF57 and WL tolerant cv. TF58) cultivars exposed to WL condition for 21 days resulted in a higher increase of both $\mathrm{O}_{2}{ }^{\bullet-}$ and MDA contents in susceptible TF57 cultivar, compared to the tolerant TF58 (Table 1; [118]).

\subsection{High Light}

The primary energy source for plants is light. Still, high light (HL) impairs the photosynthetic ETC in PSII, which may lead to the production of ${ }^{1} \mathrm{O}_{2}$, resulting in a delayed recovery period of D1 in 
the PSII core [120]. Furthermore, during electron transfer to $\mathrm{O}_{2}, \mathrm{O}_{2}{ }^{\bullet-}$ can be produced at PSI by Mehler reaction or at PSII through $\mathrm{Q}_{\mathrm{A}}$ to $\mathrm{Q}_{\mathrm{B}}$ pathway, and $\mathrm{H}_{2} \mathrm{O}_{2}$ can be formed by the univalent reduction of $\mathrm{O}_{2}$ at ETC in the plant cell (Table 1; [7]).

According to Awad et al. [121], A. thaliana double mutants deficient in two plastids 2-Cys PRXs (2-Cys PRX A and B, 2cpa 2cpb) and triple mutants deficient in 2-Cys PRXs and tAPX (2cpa 2cpb tapx) leads to accumulation of $\mathrm{O}_{2}{ }^{\bullet-}$ and $\mathrm{H}_{2} \mathrm{O}_{2}$ and causes photo-bleaching of leaf tissue in HL stress. Iris pumila grown in full sunlight had 20\% higher MDA content than those grown in shade [122]. Shengxin et al. [123] also noted increased $\mathrm{MDA}, \mathrm{O}_{2}{ }^{\bullet-}$, and $\mathrm{H}_{2} \mathrm{O}_{2}$ values in rapeseed (B. napus L. cv. Zhongshuang11) seedlings under HL ( $550 \pm 20 \mu \mathrm{mol}$ photons $\left.\mathrm{m}^{-2} \mathrm{~s}^{-1}, 16 \mathrm{~h}\right)$. In contrast, Lima et al. [124] found no significant change in MDA and $\mathrm{H}_{2} \mathrm{O}_{2}$ in 55-d-old cashew plants (Anacardium occidentale $\mathrm{L}$.) treated with water deficit followed by HL $\left(850 \mu \mathrm{mol}\right.$ photons $\left.\mathrm{m}^{-2} \mathrm{~s}^{-1}, 5 \mathrm{~d}\right)$ showing resistance against water deficit and HT stresses. Recently, Zha et al. [125] divided lettuce plants (Lactuca sativa L. cv. "Yidali") into three groups of light intensity such as low light (LL; $100 \mu \mathrm{mol} \mathrm{m}^{-2} \mathrm{~s}^{-1}$ ), medium light (ML; $200 \mu \mathrm{mol} \mathrm{m} \mathrm{m}^{-2} \mathrm{~s}^{-1}$ ), and high light (HL; $300 \mu \mathrm{mol} \mathrm{m}^{-2} \mathrm{~s}^{-1}$ ). They observed that the $\mathrm{H}_{2} \mathrm{O}_{2}$ content increased in lettuce leaves at ML and $\mathrm{HL}$, whereas $\mathrm{O}_{2}{ }^{--}$content increased only in the HL. These increased levels of $\mathrm{H}_{2} \mathrm{O}_{2}$ and $\mathrm{O}_{2}{ }^{\bullet-}$ contents were seen during the first 6 days of treatment but decreased at 9 days with increased trends found again at 12 days of treatment. The MDA content showed a similar trend to $\mathrm{O}_{2}{ }^{\bullet-}$ content. In contrast, it was also reported that the $\mathrm{H}_{2} \mathrm{O}_{2}$ and $\mathrm{O}_{2}{ }^{\bullet-}$ contents remained relatively constant, respectively, at LL stress on the first 9 days of treatment and again increased at 12 days as seen in HL lettuce leaves. All these reports show that HL stress enhanced oxidative stress as depicted by oxidative stress markers. At the same time, the resistant plant genotypes are less susceptible to oxidative damage, compared to sensitive genotypes.

\subsection{Oxidative Stress under UV-Radiation}

The UV radiation (200-400 $\mathrm{nm}$ ) is detrimental to nucleotides and proteins; consequently, exposure to this radiation causes excess ROS production in plants [126]. Considerable damage to proteins and membranes exerts inhibiting effects on the functioning of mitochondria and chloroplasts, resulting in ROS production [127]. Apart from that, reduction in other plant metabolic functions like $\mathrm{CO}_{2}$ assimilation, stomatal conductance, electron transport, and net photosynthesis may also account for the production of ROS in plants exposed to UV radiation [128]. Different experiments have been conducted to understand the UV-radiation-induced oxidative damages, including higher $\mathrm{H}_{2} \mathrm{O}_{2}$ and $\mathrm{O}_{2}{ }^{\bullet-}$ generation, MDA content, and EL. Tripathi et al. [129] observed increased contents of $\mathrm{O}_{2}{ }^{\bullet-}, \mathrm{H}_{2} \mathrm{O}_{2}$, MDA, and higher EL in T. aestivum L. seedlings exposed to two levels of UV-B radiation: ambient $\left(8.6 \mathrm{~kJ} \mathrm{~m}^{-2} \mathrm{~d}^{-1}\right)$ and enhanced (ambient $\left.+2.8 \mathrm{~kJ} \mathrm{~m}^{-2} \mathrm{~d}^{-1}\right)$. G. max L. plants grown under UV-C light with $0.284 \mathrm{~mW} \mathrm{~cm}^{-2}$ intensity $\left(20 \mathrm{~min} \mathrm{~d}^{-1}\right)$ resulted in remarkably higher $\mathrm{O}_{2}{ }^{\bullet-}, \mathrm{H}_{2} \mathrm{O}_{2}$, and MDA contents [130]. Four hours of UV-B radiation causes higher levels of EL, MDA, and $\mathrm{O}_{2}{ }^{\bullet-}$ contents in Morus alba seedlings under dark conditions [131]. Enhanced ROS and oxidative stress biomarkers reveal that UV-radiation poses an oxidative stress condition.

\subsection{Elevated Ozone}

Stomata, a crucial interface for gas exchange between plants and the atmosphere, are reported to be affected by the $\mathrm{O}_{3}$ concentration. $\mathrm{O}_{3}$ imposes phytotoxic impacts on plants via entering through stomata. Exposure to elevated levels of ozone induces oxidative stresses in plants via dissolving entered $\mathrm{O}_{3}$ in the aqueous phase of substomatal cavity producing excessive ROS beyond the scavenging capacity of a plant's intrinsic defense machinery [132]. Depending on the concentration and environmental situations, $\mathrm{O}_{3}$ affects the plants to different degrees by causing specific biochemical and molecular responses [133]. For plants acclimated to $\mathrm{O}_{3}$ stress, $\mathrm{O}_{3}$ signals can initiate PCD during biotic and abiotic stress conditions [134].

The sudden reaction of $\mathrm{O}_{3}$ with membrane fatty acids motivates peroxidative processes [135]. In pomegranate, $\mathrm{O}_{3}$ exposure caused a $10 \%$ increase in $\mathrm{O}_{2}{ }^{\bullet-}, 225 \%$ in $\mathrm{H}_{2} \mathrm{O}_{2}$, and MDA by 2-fold, 
compared to controls [136]. Dolker and Agarwal [137] demonstrated a significant elevation in MDA content in Ischaemum rugosum Salisb and Malvastrum coromandelianum L. under elevated $\mathrm{O}_{3}$ exposure of nine months. In wheat, exposure to $\mathrm{O}_{3}$ showed an increase in $\mathrm{H}_{2} \mathrm{O}_{2}, \mathrm{O}_{2}{ }^{\bullet-}, \mathrm{OH}^{\bullet}$ and MDA levels [138]. Lee et al. [139] reported an increase in MDA under $\mathrm{O}_{3}$ (86 and 56\%) stress compared to controls at 7 and 14 days after exposure, respectively. A similar trend was shown for $\mathrm{O}_{3}$ exposure regarding $\mathrm{H}_{2} \mathrm{O}_{2}, \mathrm{O}_{2}{ }^{\bullet-}$, and $\bullet{ }^{\bullet} \mathrm{OH}$ [139]. Ozone-induced oxidative stress is also associated with the alteration in gas exchange, photosynthetic efficiency, and water relations [140-142].

\subsection{Soil Acidity and Alkalinity}

Under extreme $\mathrm{pH}$ conditions, the plasma membrane proton pumps try to combat the stress by influx and efflux of $\mathrm{H}^{+}$. Still, $\mathrm{pH}$ alteration and the excitation pressure lead to the toxic free radical generation together with the severe disruption of cellular and enzymatic activity failures [143]. For instance, Bhuyan et al. [144] investigated the effects of extreme acidic $\mathrm{pH}$ (3.5) on wheat (T. aestivum $\mathrm{L}$. cvs. BARI Gom-21, 24, 25, 26, and 30) genotypes and increased $\mathrm{H}_{2} \mathrm{O}_{2}$ content together with increased LPO and LOX activity in all cultivars was found. Similarly, Liu et al. [145] found increased cell membrane injury and MDA content in Medicago sativa L. cv. Gongnong No. 1, under alkaline stress ( $\mathrm{pH}$ 11.2). Later on, Bhuyan et al. [146] studied T. aestivum L. cv. BARI Gom-25 with both extremely acidic ( $\mathrm{pH}$ 4.0) and alkaline ( $\mathrm{pH}$ 8.5) $\mathrm{pH}$ and found increased levels of MDA and $\mathrm{H}_{2} \mathrm{O}_{2}$ and LOX activity pointed out oxidative stress under extreme $\mathrm{pH}$. Therefore, the reviewed research findings presented in this section indicate that soil acidity and alkalinity stresses increase oxidative damage in plants.

In addition, acidity stress accelerated toxic metals/metalloids ( $\mathrm{Fe}, \mathrm{Cu}, \mathrm{Mn}, \mathrm{Zn}$, and $\mathrm{Al}$ ) toxicity, together with essential nutrients $(\mathrm{P}, \mathrm{Mg}, \mathrm{Ca}, \mathrm{K}$, and $\mathrm{Na}$ due to substantial replacement of cations for $\mathrm{H}^{+}$) deficiency and considered as a major limiting factor for plant growth in acid soils $[143,147,148]$. Similarly, alkalinity stress creates $\mathrm{P}, \mathrm{Fe}, \mathrm{Zn}, \mathrm{Mn}, \mathrm{Cu}, \mathrm{Mo}$, and B deficiencies. Contrarily, alkaline soils are characterized by $\mathrm{B}, \mathrm{Na}$, and $\mathrm{Cl}$ toxicities [149]. Nutrient deficiency and metals/metalloids toxicity induced oxidative stress is well studied [150-157]. Acidity induced N, P, K, Ca, Mg, and S deficiency as well as $\mathrm{Fe}, \mathrm{Mn}, \mathrm{B}, \mathrm{Zn}$, and $\mathrm{Cu}$ excess was found, with increased ROS level and oxidative stress as well as disrupted redox balance and antioxidant defense $[144,158]$. Therefore, it could be assumed that acidity or alkalinity induced nutrient deficiency and the metals/metalloids toxicity might be one of the causes for oxidative stress in plants.

On the other hand, plant cells require cytoplasmic $\mathrm{pH}$ 7.0-7.5 to maintain the normal physiological activities [159]. It was reported that a single unit decrease of external growing media $\mathrm{pH}$ reduces 0.1 units of the cytoplasmic $\mathrm{pH}$ [160]. Similarly, increases in external growing media $\mathrm{pH}$ causes precipitation of $\mathrm{P}$ and other metal ions, consequently increases the absorption of inorganic anions, and disrupts the ion balance [161]. Therefore, both acidic and alkaline $\mathrm{pH}$ of growing media alter $\mathrm{pH}$ homeostasis, inactivate enzymes, and overgenerate ROS and creates oxidative stress and are considered as the major limiting factors for plant growth [148].

\subsection{Herbicides Toxicity}

Herbicides are often used in cultivated crop plants to easily control weeds. Still, the unconscious use of herbicides may cause oxidative stress in plants. Herbicides increase oxidative stress by overproducing ROS, which destroys plant cell membranes, lipids, photosynthetic pigments, and enzyme activities; therefore, they affect plant growth and productivity (Table 1). Herbicide glyphosate caused oxidative stress in plants by restricting the shikimate pathway, which leads to overproduction of ROS, which disrupted redox homeostasis $[6,162]$. The application of glyphosate significantly inhibited the growth of $H$. vulgare $\mathrm{L}$. in response to the higher accumulation of $\mathrm{H}_{2} \mathrm{O}_{2}(82 \%$ in leaves and $123 \%$ in roots) and $\mathrm{O}_{2}{ }^{\bullet-}$, which increased the LPO (MDA; $45 \%$ in leaves and 104\% in roots) [162]. Glyphosate application in tomato also increased $\mathrm{H}_{2} \mathrm{O}_{2}$ and $\mathrm{O}_{2}{ }^{--}$by 40 and $100 \%$, respectively [6]. Liu et al. [163] observed the increased MDA content with increasing the concentration of picloram 
in Eupatorium adenophorum. Oxidative stress is also observed in various plants after the application of paraquat. Oxidative stress indicators such as MDA, $\mathrm{H}_{2} \mathrm{O}_{2}$, and $\mathrm{O}_{2}{ }^{\bullet-}$ considerably increased by the application of paraquat in mustard [164]. Besides, the application of the herbicide 2,4-D and its formulation imposed oxidative stress by increasing XOD and LOX activity in pea plants [165] and concomitant increase in MDA content in M. aquaticum plants [166].

Alves et al. [167] applied different doses of fomesafen and sulfentrazone in Raphanus sativus, Avena sativa, Lupinus albus, and V. sativa, and, where a higher generation of TBARS and altered activity of CAT, APX, and GPX indicate the oxidative stress. Among different species, V. sativa, R. sativus, and L. albus showed a higher damaging effect from sulfentrazone $\left(1.2 \mathrm{~kg} \mathrm{ha}^{-1}\right)$. Effect of different herbicide applications such as 2,4-D, metsulfuron, metribuzin, iodosulfuron, clodinafop, and bentazon, were studied in the wheat plant. Photosynthesis, transpiration rate, and stomatal conductance were reduced under herbicide toxicity. Lipid peroxidation, CAT activity, and phenols contents were higher, while chl and carotenoids were lower in herbicide stressed wheat plants [168]. Due to the toxic effect of different herbicides, including oxyfluorfen, oxyfluorfen, and pendimethalin, rice plants showed phytotoxicity with reduced height, altered metabolism, accumulation of ROS, and alteration of non-enzymatic and enzymatic components of antioxidant defense machinery. Reduction in photosynthetic pigments, Pro accumulation, protein content, photosynthesis rate, and efficiency of carboxylation, as well as excessive generation of LPO was noticeable as an outcome of the phytotoxic effect of herbicides [169]. A substantial increase in MDA and activity of GR and SOD indicated the paraquat-induced oxidative damage in soybean plants [170].

Table 1. Examples of oxidative stress in plants under various environmental stresses.

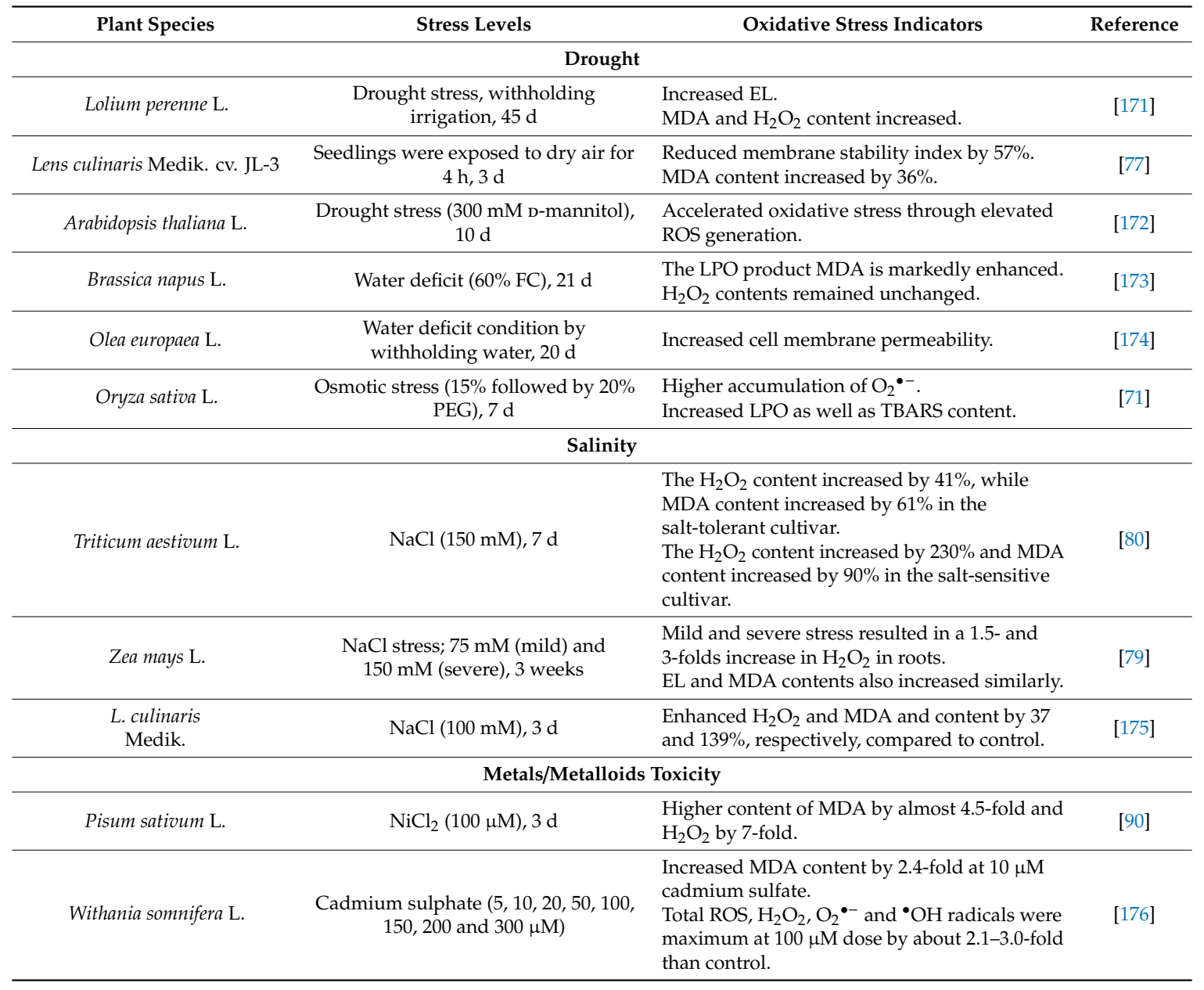


Table 1. Cont.

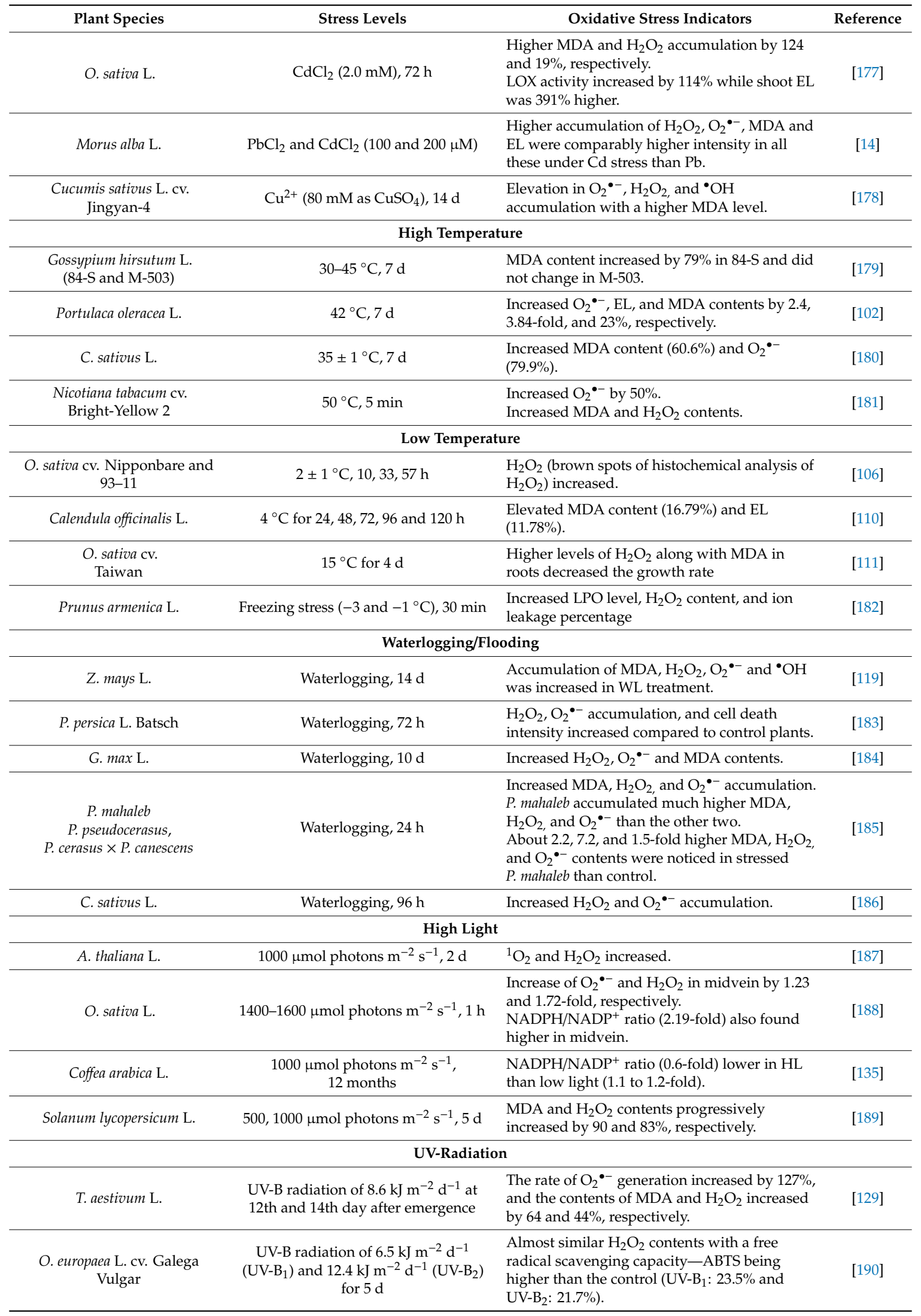


Table 1. Cont.

\begin{tabular}{|c|c|c|c|}
\hline Plant Species & Stress Levels & Oxidative Stress Indicators & Reference \\
\hline \multicolumn{4}{|c|}{ Elevated Ozone } \\
\hline G. $\max \mathrm{L}$. & $80 \mathrm{ppb}, 6 \mathrm{~h} \mathrm{~d}^{-1}$ for $5 \mathrm{~d}$ & $\begin{array}{l}\text { TBARS content was higher in saplings of } \\
\text { Tracajá cultivar of soybean than in Sambaíba. } \\
\text { Plants of both cultivars showed a 2-fold } \\
\text { increase in TBARS content than plants } \\
\text { maintained under filtered air. }\end{array}$ & [191] \\
\hline $\begin{array}{l}\text { N. tabacum L. } \\
\text { G. max L., and } \\
\text { Populus tremula L. }\end{array}$ & 96,74, and $64 \mathrm{ppb}$ & $\begin{array}{l}\text { Increase of MDA content by } 97.0,65.3 \text {, and } 63.4 \text {, } \\
\text { respectively in tobacco, soybean, and poplar, } \\
\text { respectively. } \\
\text { Increased } \mathrm{O}_{2}{ }^{\bullet-} \text { content in poplar (by } 18.4 \% \text { ), } \\
\text { tobacco (by } 18.8 \% \text { ), and soybean (by } 45.6 \% \text { ). } \\
\text { Increased } \mathrm{H}_{2} \mathrm{O}_{2} \text { content of tobacco and soybean } \\
\text { by } 26.2 \text { and } 82.0 \% \text {, respectively, whereas had no } \\
\text { effect on poplar. }\end{array}$ & [193] \\
\hline T. aestivum $\mathrm{L}$. & $59.6 \mathrm{ppb} ; 122 \mathrm{~d}$ & MDA content increased in HD2967. & [195] \\
\hline \multicolumn{4}{|c|}{ Acidity and Alkalinity } \\
\hline O. sativa $\mathrm{L}$. & $\begin{array}{l}\text { Simulated acid rain stress ( } \mathrm{pH} 2.0 \text { or } \\
\qquad 3.0,4.0)\end{array}$ & $\begin{array}{l}\text { The } \mathrm{H}_{2} \mathrm{O}_{2} \text { content in the root increased with the } \\
\text { decrease of the } \mathrm{pH}(3.0 \text { or } 2.0) \text {. } \\
\text { Decreased antioxidant enzyme activities. } \\
\text { Increased cellular damages. }\end{array}$ & [196] \\
\hline $\begin{array}{l}\text { S. lycopersicum L. cv. } \\
\text { Micro-Tom }\end{array}$ & $\begin{array}{l}\text { Simulated acid rain stress ( } \mathrm{pH} 2.5 \text { and } \\
5.6), 17 \mathrm{~d}\end{array}$ & $\begin{array}{l}\text { Overaccumulation of ROS. } \\
\text { Damaged grana lamella of the chloroplast. } \\
\text { Increase of MDA and } \mathrm{H}_{2} \mathrm{O}_{2} \text { contents by } 63 \text { and } \\
45 \% \text {, respectively, compared to control. }\end{array}$ & [197] \\
\hline B. oleracea L. cv 'Bronco' & $\begin{array}{l}\text { Alkaline stress }(50 \mathrm{mM} \mathrm{NaHCO} \\
\left.\qquad \mathrm{Na}_{2} \mathrm{CO}_{3}\right), \mathrm{pH} 9,25 \mathrm{~d}\end{array}$ & $\begin{array}{l}\text { Greater contents of MDA and higher LOX } \\
\text { activity. } \\
\text { Increased level of ROS specially amplified } \\
\mathrm{O}_{2}^{\bullet-} \text { content. }\end{array}$ & [199] \\
\hline O. sativa $\mathrm{L}$. & $\begin{array}{l}\text { Simulated acid rain (SAR) stress }(\mathrm{pH} \\
5.5,5.0,4.5,4.0,3.5,3.0 \text { or } 2.5), 5 \mathrm{~d}\end{array}$ & $\begin{array}{l}\text { Overaccumulation of ROS exceeded the } \\
\text { scavenging ability of the antioxidant enzymes. } \\
\text { Disrupted membrane permeability. } \\
\text { Elevated level of } \mathrm{H}_{2} \mathrm{O}_{2}, \mathrm{O}_{2}{ }^{\bullet-} \text { and MDA, } \\
\text { contents by } 107,155 \text { and } 187 \% \text { respectively, } \\
\text { were found under the acid rain stress (pH 2.5) } \\
\text { over the control. }\end{array}$ & [200] \\
\hline \multicolumn{4}{|c|}{ Herbicides Toxicity } \\
\hline Hordeum vulgare $\mathrm{L}$. & Glyphosate (6 mM) & $\begin{array}{l}\text { Increased lipid peroxidation (MDA; } 45 \% \text { in } \\
\text { leaves and } 104 \% \text { in roots) and } \mathrm{H}_{2} \mathrm{O}_{2}(82 \% \text { in } \\
\text { leaves and } 123 \% \text { in roots), and } \mathrm{O}_{2}{ }^{\bullet-} \text { generation. }\end{array}$ & [162] \\
\hline Salvinia natans L. & $\begin{array}{c}\text { Glyphosate }(0.006,0.03,0.15,0.3 \text { and } \\
0.45 \mathrm{mM})\end{array}$ & Enhanced MDA and $\mathrm{H}_{2} \mathrm{O}_{2}$ production. & [201] \\
\hline S. lycopersicum $\mathrm{L}$. & Glyphosate $(2,4$ and $6 \mathrm{mM})$ & $\begin{array}{l}\text { Higher } \mathrm{H}_{2} \mathrm{O}_{2}(40 \%) \text {, and } \mathrm{O}_{2}^{\bullet-}(100 \%) \text { contents } \\
\text { in root at maximum concentration. }\end{array}$ & [6] \\
\hline
\end{tabular}




\section{Overview of Plant Antioxidant Defense System}

Antioxidants are considered vital components for scavenging ROS, which play a critical role in abiotic stresses [204]. Plants have developed a multifaceted antioxidant defense network to reduce ROS overgeneration under different abiotic stresses (Figure 4; [205]). The antioxidant defense system consists of several antioxidants of low molecular weight (AsA, ascorbate; GSH, glutathione; non-protein amino acids; phenolic compounds; $\alpha$-tocopherol; and some alkaloids) and antioxidant enzymes (SOD; CAT, catalase; POX, peroxidases; APX, ascorbate peroxidase; MDHAR, monodehydroascorbate reductase; DHAR, dehydroascorbate reductase; GR, glutathione reductase; GPX, glutathione peroxidase; GST, glutathione $S$-transferase).

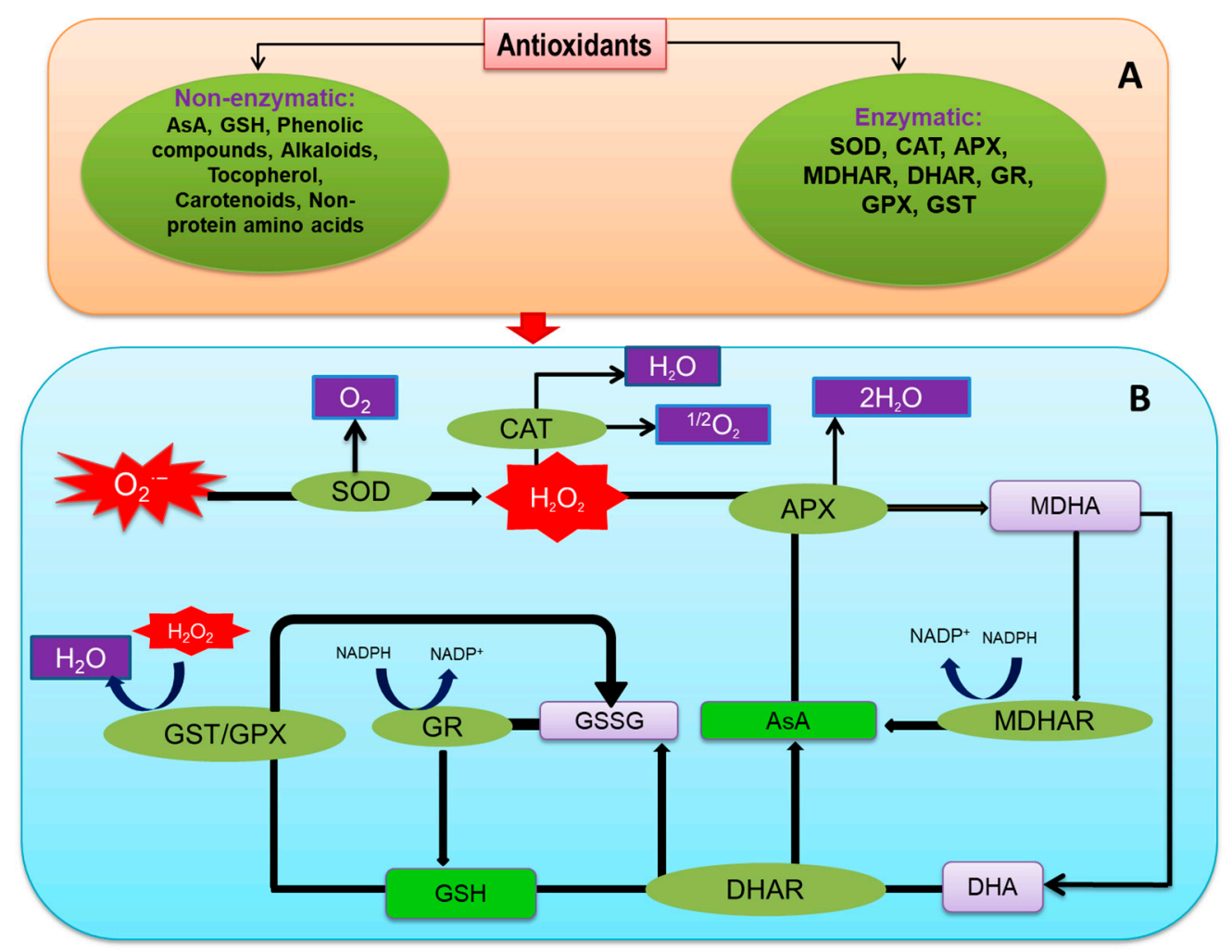

Figure 4. Outline of antioxidant defense mechanisms in plants; (A) types of antioxidants and (B) mechanism of antioxidant enzymes and low molecular weight antioxidants to detoxify ROS. Additional details are in the text.

\subsection{Low Molecular Weight Antioxidants}

\subsubsection{Ascorbic Acid}

Ascorbic acid (vitamin C) is a strong water-soluble antioxidant, abundant in the active growing parts such as meristems, photosynthetic cells, root tips, flowers, and young fruits [206]. Having the potential to donate electrons as a co-enzyme, the AsA participates significantly in scavenging ROS upon stresses [46]. Ascorbate also participates in regenerating $\alpha$-tocopherol from tocopherol radical scavenging $\mathrm{O}_{2}{ }^{\bullet-}$ and ${ }^{\bullet} \mathrm{OH}$. The growth and development of plants are considerably influenced by AsA production under abiotic stresses [207]. By regulating cellular water status, AsA improved enzymatic detoxification of $\operatorname{ROS}\left(\mathrm{H}_{2} \mathrm{O}_{2}\right)$ to protect the cells. In plants, many phytohormone biosynthesis pathways are regulated by AsA [208]. Therefore, the exogenous application of AsA increased plant growth by regulating hormonal balance and ion homeostasis [209]. Reports suggested that exogenous AsA application maintained the growth and biochemical processes of cauliflower [210], wheat [211], cucumber [207], canola [212], soybean [213], rapeseed [214], and grapes [215]. 


\subsubsection{Glutathione}

As a low molecular weight antioxidant and a non-protein thiol, GSH plays a critical function in regulating intracellular defense by scavenging ROS. Besides, GSH maintains redox homeostasis as a component of the AsA-GSH cycle [46]. It also plays vital roles in detoxification of xenobiotics, signal transduction, transportation of sulfate, and metabolites conjugation [216]. Glutathione also detoxifies atmospheric pollutants such as $\mathrm{O}_{3}$ and $\mathrm{NO}_{2}$. It also actively participates in recycling the AsA and $\alpha$-tocopherol [217]. Upon stress, the frequent stimulation of GSH indicated the possible role of regulating defense mechanisms [218].

\subsubsection{Tocopherol}

The antioxidant tocopherol is found as alpha $(\alpha)$, beta $(\beta)$, gamma $(\gamma)$, and delta $(\delta)$ forms; mostly synthesized in photosynthetic organs. They protect the photosynthetic membrane by scavenging ROS, mainly ${ }^{1} \mathrm{O}_{2}$ and $\bullet \mathrm{OH}[219]$.

\subsubsection{Carotenoids}

The carotenoids mainly accomplish three important activities: (i) absorbing light spectra (between 400 and $550 \mathrm{~nm}$ wavelengths), (ii) scavenging harmful ROS during photosynthesis, and (iii) protecting the complex light-harvesting proteins as well as stabilizing thylakoid membranes [220,221]. Carotenoids have a polyene backbone in their structure, which consists of a series of $\mathrm{C}=\mathrm{C}$ bonds. This particular characteristic is mainly responsible for pigmentation and ROS quenching ability [222].

\subsubsection{Flavonoids}

Flavonoids are low molecular weight and contain hydroxylation patterns in their molecular structure, indicating the antioxidant capacity [223]. Flavonoids decrease cell damage in plants by scavenging free radicals and protecting cell membranes from LPO [224]. The genes related to flavonoid biosynthesis are highly expressed under stress conditions; therefore, activating defense mechanisms by increasing flavonoid levels. Apart from the antioxidant activity, flavonoids can regulate auxin transport in vivo and give photoprotection. Moreover, flavonoids protect plants against UV light damage by absorbing UV radiation and act as sunscreens. Although light is essential for flavonoid biosynthesis, exposure to UV radiation induces higher levels of flavonoids in plants, which further act in the ROS removal mechanism in plants [225].

\subsection{Antioxidant Enzymes}

\subsubsection{Superoxide Dismutase (EC 1.15.1.1)}

Superoxide dismutase is a metalloenzyme that shows the frontline defense under excessive ROS generation. In most plant cells, the available SOD concentration is $\sim 10^{-5} \mathrm{M}$ [226]. Based on metal co-factor at active sites, three main SOD types are described- $\mathrm{Cu} / \mathrm{Zn}-\mathrm{SOD}, \mathrm{Mn}-\mathrm{SOD}$, and Fe-SOD. In the antioxidant defense network, $\mathrm{O}_{2}{ }^{\bullet-}$ is dismutased by SOD into $\mathrm{H}_{2} \mathrm{O}_{2}$, this also reduces the option of ${ }^{\bullet} \mathrm{OH}$ generation via Haber-Weiss reaction (Figure 4; [226]).

\subsubsection{Catalases (EC 1.11.1.6)}

The tetrameric haem-containing CAT enzyme rapidly decomposes $\mathrm{H}_{2} \mathrm{O}_{2}$, producing $\mathrm{H}_{2} \mathrm{O}$ and $\mathrm{O}_{2}$. All aerobic organisms contain CAT, a unique enzyme for ROS detoxification without any reducing equivalent [227]. Among the antioxidant enzymes CAT possesses, the maximum turnover rate and 26 million $\mathrm{H}_{2} \mathrm{O}_{2}$ molecules can be converted by one CAT molecule in one minute [217]. CAT activity is found in peroxisomes, mitochondria, and cytosol [228]. 


\subsubsection{Peroxidases (EC. 1.11.1.7)}

Peroxidases are glycoproteins containing a polypeptide chain with 300-350 amino acid residues. The POX contains three domains-among which a proximal heme-binding domain and a distal heme-binding domain is identified, but the other one is still unknown [229]. Peroxidase mainly oxidizes phenolic compounds ( $\mathrm{PhOH}$ ) and produces phenoxyl radical $(\mathrm{PhO})^{\bullet}$ ), where $\mathrm{H}_{2} \mathrm{O}_{2}$ contributes to this reaction as an electron acceptor, and it is converted to $2 \mathrm{H}_{2} \mathrm{O}$.

\subsubsection{Ascorbate Peroxidase (EC 1.11.1.1)}

Another class I heme-peroxidase is APX occurring in several isoforms (cAPX, cytosolic APX; mitAPX, mitochondrial APX; chAPX, chloroplastic APX; and microbody (including peroxisomal and glyoxysomal) APX), mAPX; [31]. All the isoforms function to scavenge $\mathrm{H}_{2} \mathrm{O}_{2}$, but the activity stops without the presence of AsA [46]. Within the AsA-GSH cycle, APX participates in detoxifying $\mathrm{H}_{2} \mathrm{O}_{2}$ and oxidizes AsA to produce monodehydroascorbate (MDHA) and subsequent dehydroascorbate (DHA) (Figure 4).

\subsubsection{Monodehydroascorbate Reductase (EC 1.6.5.4)}

In the AsA-GSH cycle, MDHAR is an NADH or NADPH-dependent flavin adenine dinucleotide enzyme containing a thiol group involved in the phenoxyl radical reduction and AsA regeneration from MDHA [46,220]. MDRAH has several isoforms based on localization. Therefore, MDHAR genes are present in different cell components like mitochondria, chloroplasts, glyoxysomes, peroxisomes, and cytosol [230]. Respective genes and locations are essential to knowing the role of each isoform. One MDHAR gene can produce two isoforms, and MDHAR genes can vary in different plant species (Figure 4; Table 2; [230]).

Table 2. Antioxidant metabolism and defense under various environmental stresses.

\begin{tabular}{|c|c|c|c|}
\hline Plant Species & Stress Levels & Antioxidant Metabolism & Reference \\
\hline \multicolumn{4}{|c|}{ Drought } \\
\hline Lolium perenne L. & $\begin{array}{l}\text { Drought stress (withholding } \\
\text { irrigation), } 45 \mathrm{~d}\end{array}$ & $\begin{array}{l}\text { Significant improvement of APX, CAT, and } \\
\text { SOD activity, but POD activity remained } \\
\text { unchanged up to } 15 \mathrm{~d} \text {, whereas increased } \\
\text { thereafter. }\end{array}$ & {$[171]$} \\
\hline $\begin{array}{l}\text { Vigna radiata } \\
\text { L. cv. BARI Mung-2 }\end{array}$ & Drought stress (5\% PEG), $48 \mathrm{~h}$ & $\begin{array}{l}\text { Decreased AsA and high DHA content with } \\
\text { reduced AsA/DHA ratio. } \\
\text { Downregulated GSH/GSSG ratio. } \\
\text { Increased GR, APX, GPX, and GST activity } \\
\text { with reduced CAT and MDHAR activity. }\end{array}$ & [69] \\
\hline $\begin{array}{l}\text { Lens culinaris L. Cultivars: } \\
\text { drought tolerant (PDL-2) and } \\
\text { sensitive (JL-3) }\end{array}$ & $\begin{array}{l}\text { Drought stress (seedlings exposed to } \\
\text { dry air for } 4 \mathrm{~h}), 3 \mathrm{~d}\end{array}$ & $\begin{array}{l}\text { Upregulation of SOD, APX, and GPX in both } \\
\text { tolerant and sensitive cultivars (higher in } \\
\text { PDL-2 by } 32,44 \text {, and } 57 \% \text { than in JL-3). } \\
\text { CAT activity showed no significant difference. }\end{array}$ & [77] \\
\hline T. aestivum L. & $\begin{array}{c}\text { Drought stress }(70,50 \text {, and } 35 \% \text { of soil } \\
\text { water holding capacity) }\end{array}$ & $\begin{array}{l}\text { Uplifting SOD and CAT activities in a } \\
\text { dose-dependent manner compared to } \\
\text { respective control. }\end{array}$ & [74] \\
\hline $\begin{array}{l}\text { Brassica napus L. cvs. Dunkeld } \\
\text { and Cyclone }\end{array}$ & Water deficit (60\% FC), $21 \mathrm{~d}$ & $\begin{array}{l}\text { Slightly enhanced total phenolics in both } \\
\text { canola cultivars. } \\
\text { Increased activities of POD and CAT enzymes. } \\
\text { Dunkeld performed better compared to } \\
\text { Cyclone in POD activity, whereas, in the case of } \\
\text { SOD activity, Cyclone was better. }\end{array}$ & [173] \\
\hline $\begin{array}{l}\text { Sorghum bicolor } \text { L. cvs. M-81E } \\
\text { and Roma }\end{array}$ & $\begin{array}{l}\text { Drought stress (sand water content } \\
4.2 \%), 7 \mathrm{~d}\end{array}$ & $\begin{array}{l}\text { APX and SOD activities increased in both } \\
\text { cultivars. } \\
\text { M-81E had uplifted enzymatic antioxidant } \\
\text { activities as well as stronger scavenging ability } \\
\text { than Roma. }\end{array}$ & [105] \\
\hline
\end{tabular}


Table 2. Cont.

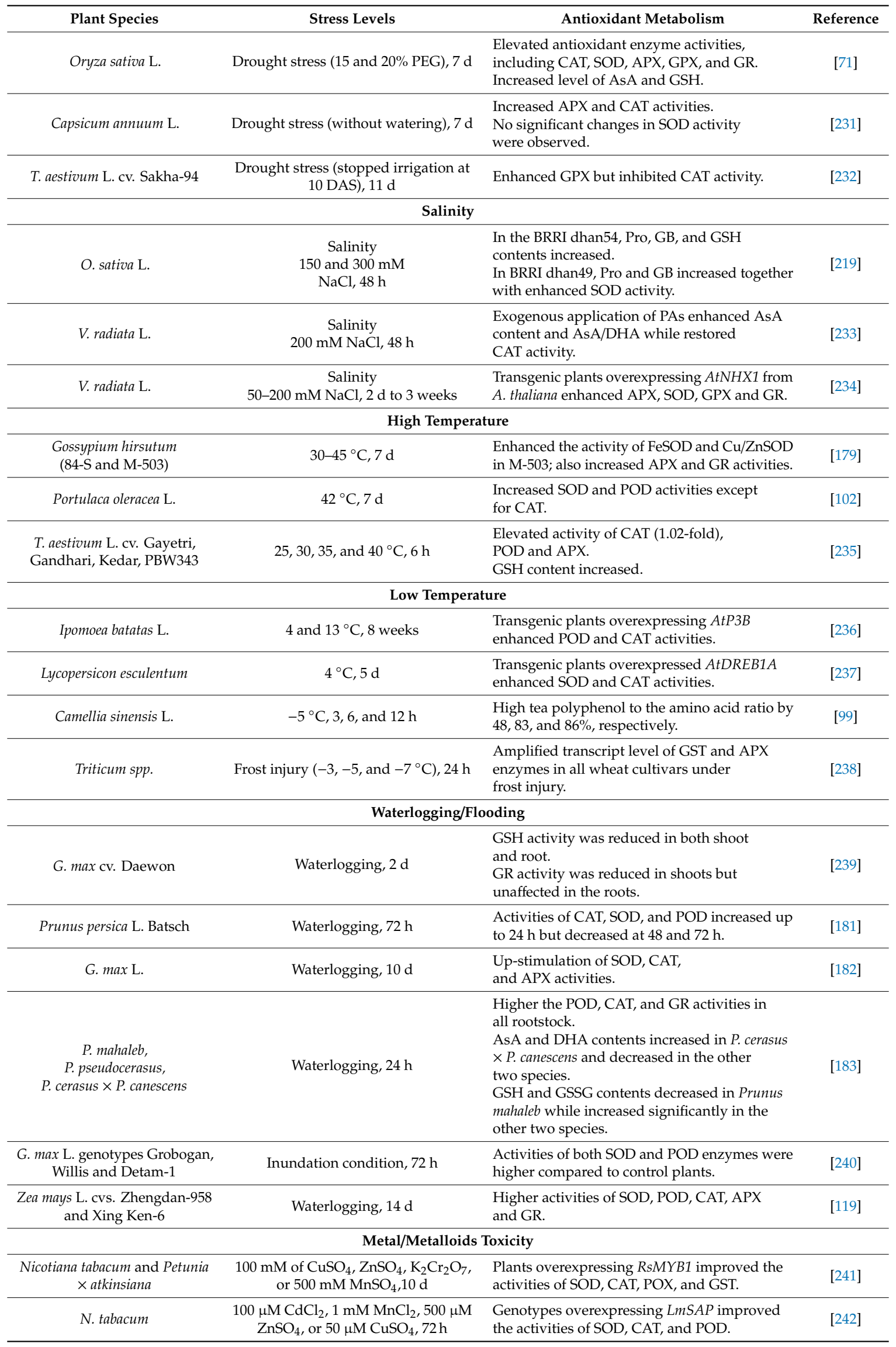


Table 2. Cont.

\begin{tabular}{|c|c|c|c|}
\hline Plant Species & Stress Levels & Antioxidant Metabolism & Reference \\
\hline O. sativa $\mathrm{L}$. & $\mathrm{CdCl}_{2}(2.0 \mathrm{mM}), 72 \mathrm{~h}$ & $\begin{array}{l}\text { Decreased AsA and DHA contents with a sharp } \\
\text { increase in both GSH and GSSG contents. } \\
\text { Higher activity of APX, MDHAR, GR, } \\
\text { SOD, GPX. } \\
\text { Reduced the activity of DHAR (by 33\%), CAT } \\
\text { (by } 35 \% \text { ), and GST. }\end{array}$ & [177] \\
\hline Withania somnifera $\mathrm{L}$. & $\begin{array}{c}\mathrm{CdSO}_{4}(5 \mu \mathrm{M}, 10 \mu \mathrm{M}, 20 \mu \mathrm{M}, 50 \mu \mathrm{M}, \\
100 \mu \mathrm{M}, 150 \mu \mathrm{M}, 200 \mu \mathrm{M} \text { and } 300 \mu \mathrm{M})\end{array}$ & $\begin{array}{l}\text { Tocopherol content was the maximum at } 10 \\
\mu \mathrm{M} \text {, about } 2.75 \text {-fold. } \\
\text { GSH content increased by } 2.02 \text {-fold. } \\
\text { AsA and DHA content was enhanced by } 4.46-\text {, } \\
2.16-\text { and } 38.75 \text {-fold, respectively. } \\
\text { MDHAR, DHAR, GR, and GPX activity } \\
\text { upregulated. }\end{array}$ & [176] \\
\hline Morus alba L. & $\begin{array}{c}\mathrm{PbCl}_{2} \text { and } \mathrm{CdCl}_{2} \text { at } 100 \text { and } 200 \mu \mathrm{M} \text {, } \\
\text { respectively }\end{array}$ & $\begin{array}{l}\text { Lower activity of APX and SOD but slightly } \\
\text { increased SOD activity was found only in the } \\
\text { lower dose of } \mathrm{Pb} \text {. }\end{array}$ & [14] \\
\hline \multicolumn{4}{|c|}{ High Light } \\
\hline O. sativa L. cv. Liangyoupeijiu & $1400-1600 \mu \mathrm{mol}$ photons $\mathrm{m}^{-2} \mathrm{~s}^{-1}, 1 \mathrm{~h}$ & $\begin{array}{l}\text { CAT, DHAR, MDHAR, and POD activity were } \\
\text { higher ( } 0.147 \text { to } 0.534 \text {-fold) in leaf lamina, while } \\
\text { SOD and APX were higher in midvein. } \\
\text { The AsA and GSH contents increased, and } \\
\text { DHA and GSSG decreased. } \\
\text { AsA/DHA and GSH/GSSG ratios increased in } \\
\text { midvein. }\end{array}$ & [188] \\
\hline Anacardium occidentale $\mathrm{L}$. & $850 \mu \mathrm{mol}$ photons $\mathrm{m}^{-2} \mathrm{~s}^{-1}, 5 \mathrm{~d}$ & $\begin{array}{l}\text { CAT activity decreased while the activity of } \\
\text { APX and SOD upregulated. } \\
\text { AsA content decreased by } 25 \% \text {, and GSH } \\
\text { content increased by } 63 \% \text {. }\end{array}$ & [124] \\
\hline $\begin{array}{l}\text { A. thaliana pgr5 and WT } \\
\text { glabrous } 1\end{array}$ & $1000 \mu \mathrm{mol}$ photons $\mathrm{m}^{-2} \mathrm{~s}^{-1}, 1 \mathrm{~h}$ & $\begin{array}{l}\text { CAT activity increased in mutants than WT } \\
\text { under control. } \\
\text { DHAR activity increased in HL treated mutants. } \\
\text { Expression of } A P X 2, D H A R 1, C D S 1, C D S 2 \text {, and } \\
\text { FDS2 were down-regulated, and APX1,CAT2, } \\
\text { and FDS1 were upregulated in the mutant. }\end{array}$ & [244] \\
\hline \multicolumn{4}{|c|}{ UV-Radiation } \\
\hline T. aestivum L. cv. HP 1761 & $\begin{array}{l}\text { UV-B radiation }\left(8.6 \mathrm{~kJ} \mathrm{~m}^{-2} \mathrm{~d}^{-1}\right) \text { at } \\
12 \text { th and } 14 \text { th day after emergence }\end{array}$ & $\begin{array}{l}\text { Higher accumulation of AsA was recorded. } \\
\text { Lower SOD and APX activities were observed, } \\
\text { while CAT and GPX activities increased. }\end{array}$ & [129] \\
\hline A. thaliana cvs. C24 and rsr4-1 & $\begin{array}{l}\text { UV-B radiation }\left(3.9 \mathrm{~kJ} \mathrm{~m}^{-2}\right) \text { up to } \\
44 \mathrm{~h} \mathrm{~d}^{-1}, 4 \mathrm{~d}\end{array}$ & $\begin{array}{l}\text { Activity of SOD was not affected in C24 but } \\
\text { drastically reduced in rsr } 4-1 \text {. } \\
\text { In C24, the activity of POD, APX and GPX } \\
\text { increased while remaining unchanged in rsr4-1. }\end{array}$ & [245] \\
\hline $\begin{array}{c}\text { Olea europaea L. cv. Galega } \\
\text { Vulgar }\end{array}$ & $\begin{array}{c}\text { UV-B radiation }\left(6.5 \mathrm{~kJ} \mathrm{~m}^{-2} \mathrm{~d}^{-1}\right. \\
\left.\left.\mathrm{UV}-\mathrm{B}_{1}\right) \text { and } 12.4 \mathrm{~kJ} \mathrm{~m}^{-2} \mathrm{~d}^{-1}, \mathrm{UV}-\mathrm{B}_{2}\right) \\
5 \mathrm{~d}\end{array}$ & $\begin{array}{l}\text { Reduced activities of GR (by } 75 \% \text { ) and APX } \\
\text { (by } 36 \% \text { ) under UV-B } \mathrm{B}_{1} \text { treatment, while GR } \\
\text { increased by } 59 \% \text { under UV- } \mathrm{B}_{2} \text { treatment } \\
\text { remaining APX unaffected. } \\
\text { Activities of SOD, CAT, and GPX increased in a } \\
\text { dose-dependent manner with the highest value } \\
\text { of UV-B } \mathrm{B}_{2} \text { treatment. }\end{array}$ & [190] \\
\hline \multicolumn{4}{|c|}{ Elevated Ozone } \\
\hline
\end{tabular}


Table 2. Cont.

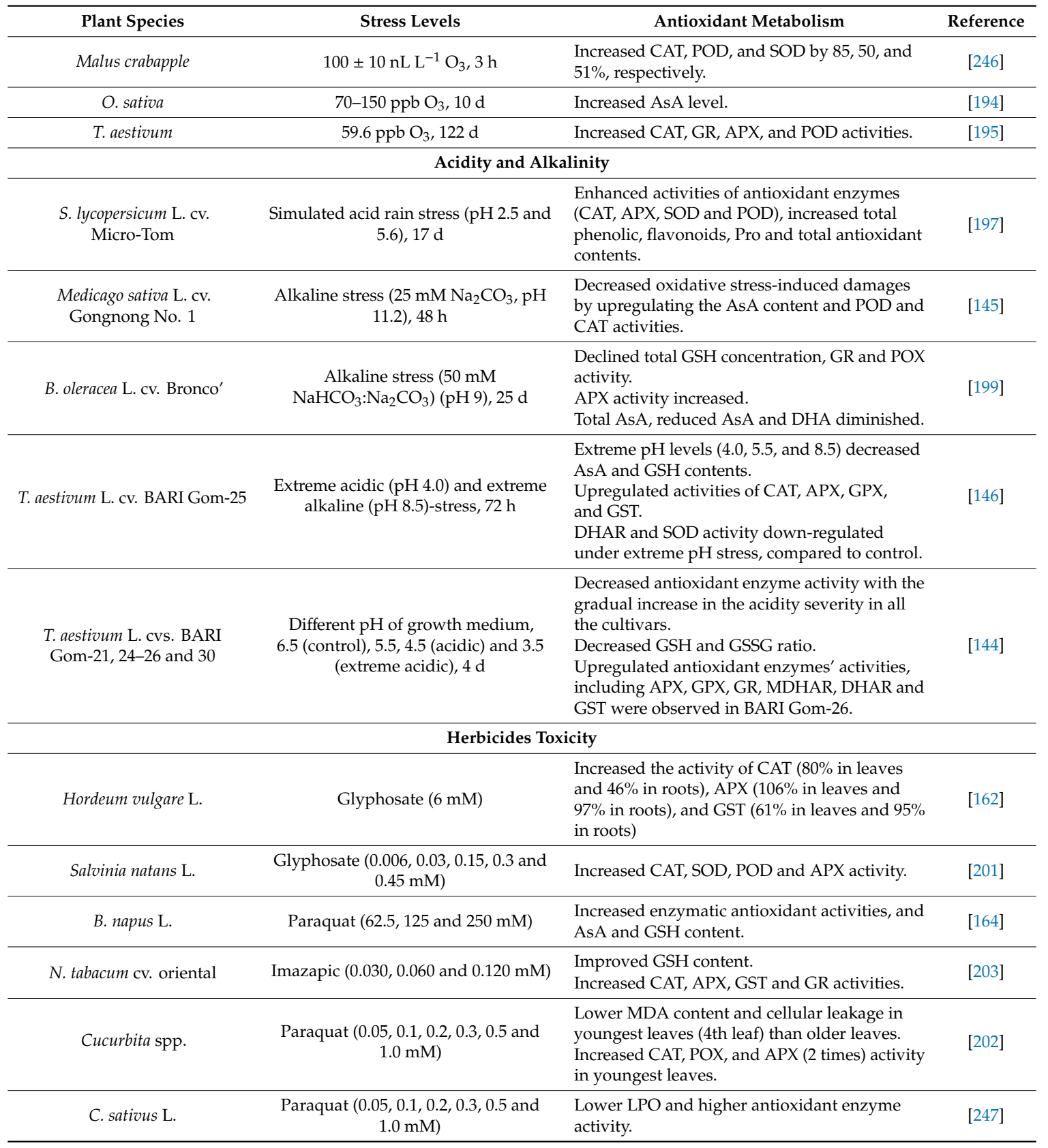

\subsubsection{Dehydroascorbate Reductase (EC.1.8.5.1)}

The enzyme DHAR, is monomeric and is included in the GST super-family, plays a vital role to regenerate AsA by an oxidative reaction, where DHA is recycled [220,248]. In this process, GSSG is from the oxidation of GSH. As a result, the enzyme is also called GSH dehydrogenase or GSH:DHA oxidoreductase [249].

\subsubsection{Glutathione Reductase (EC 1.6.4.2)}

In the AsA-GSH cycle, GR is another vital enzyme for regulating the redox homeostasis, which reduces GSSG to GSH (Figure 4; Table 2; [250]).The reaction catalyzed by GR involves two steps-in the first step, NADPH reduces the flavin moiety, which is oxidized and reduced forming a disulfide bridge, which is redox-active and generates a thiolate anion and cysteine. In the next step, one GSSG moiety binds with cysteine forming a disulfide bond, finally releasing GSH [251]. 


\subsubsection{Glutathione Peroxidases (EC 1.11.1.9)}

The enzyme GPX, is the non-heme peroxidase family member, utilizes GSH and thioredoxin, reduces $\mathrm{H}_{2} \mathrm{O}_{2}$, and protects cells from oxidative damage [252]. Eight GPX proteins were identified in Arabidopsis, mainly found in the chloroplast, mitochondria, endoplasmic reticulum, and cytosol [253]. The active site of GPX contains a thiol group (Cys residue) that can bind both GSH and thioredoxin, therefore, considered the redox regulating enzyme (Figure 4; [254,255]).

\subsubsection{Glutathione $S$-Transferases (EC 2.5.1.18)}

Glutathione $S$-transferases are a ubiquitous large enzyme family regulating versatile functions within plants [256]. The enzyme has three superfamilies based on their localization, viz. cytosolic, mitochondrial, and microsomal. The enzyme is classified into various types, for example, phi, tau, lambda, and DHAR are found in plants; where phi and tau are highly responsible for environmental stresses mitigation [257,258]. Moreover, it accelerates the activity of GPX and significantly reduces the reactive electrophile species generation (Figure 4; [232]).

\section{Antioxidant Metabolism and the Detoxification of ROS under Environmental Stress}

\subsection{Drought Stress}

Under drought stress, an adaptive strategy is activating the antioxidant defense system to fight against the oxidative stresses and to develop tolerance against drought in plants [66,70]. The AsA and GSH are the strongest among the non-enzymatic antioxidants, which provide significant protection against drought-induced oxidative stress. In O. sativa, upregulation of AsA and GSH under drought stress (PEG, 15 and 20\%) reduced oxidative damages. In B. napus cv. Bina Sharisha-3, higher AsA content was found under moderate stress level (10\% PEG), but not in severe stress (20\% PEG) levels. Moreover, in moderate and severe drought-stressed rapeseed seedlings, GSH content increased by 31 and $26 \%$, respectively, compared to controls, whereas 83 and $225 \%$ increases in GSSG contents were also documented [66]. Nahar et al. [69] demonstrated reduced AsA and enhanced DHA contents, which ultimately reduced the overall AsA/DHA ratio by $54 \%$ in $V$. radiata L. under drought stress. The GSH/GSSG ratio was also reduced, compared to controls in drought exposed V. radiata L. seedlings. Elevated antioxidant enzyme activities also contributed to scavenging the toxic free radicals and protected plants from oxidative damage [71]. Hasanuzzaman et al. [66] revealed enzymatic antioxidants; DHAR, MDHAR, GR, and APX, played essential roles along with the non-enzymatic antioxidants (AsA and GSH) to alleviate drought stress-induced oxidative damage in B. napus L. cv. Bina Sharisha-3, which decreased the MDA and $\mathrm{H}_{2} \mathrm{O}_{2}$ contents. Upon drought (20\% PEG) stress, toxic ROS overgeneration decreased by activated antioxidants in B. rapa L., where endogenous AsA and GSH levels increased together with a notable (23\%) enhancement in APX activity, as well as increased CAT, GPX, and GR, activity by 29,26 , and $81 \%$, respectively, compared to unstressed seedlings [259]. Liu et al. [76] investigated the drought stress (20\% PEG-6000, 5 d) effects on O. sativa L. subsp. japonica cv. Nipponbare which demonstrated significantly decreased CAT, APX, and SOD activities and remarkably increased peroxidase (POD) activity by 59\%. Rezayian et al. [73] studied the effect of mild to severe drought stress $(5,10$, and $15 \%$ PEG) on G. max $\mathrm{L}$. and found increased SOD and POX activities at a high intensity of stress (15\% PEG). Still, most uplifted activities of APX, CAT, and POX were found at low intensity of stress (5\% PEG). Meanwhile, uplifted tocopherol (by 26, 26, and 21\%) and total phenol $(51,32$, and $44 \%)$ contents were also demonstrated at three levels of PEG-stresses, respectively. In T. aestivum L. cv. Sakha-94 enhanced GPX activity but significantly inhibited CAT activity under drought stress, compared to controls [260]. When exposed to drought stress (irrigation at $60 \%$ of soil FC) for 20 days, an upregulated antioxidant defense system was also found in S. lycopersicum L. In this case, enzymatic antioxidants like APX, CAT, and SOD activities enhanced by 77, 110, and 66\% in contrast, and non-enzymatic antioxidants viz. $\alpha$-tocopherol, GSH, and AsA increased by 103, 93, and $81 \%$, respectively, compared to controls (Table 2; [261]). 


\subsection{Salinity}

Variations in antioxidant activities impart differential salt stress tolerance to plants. These variations are present even at the plant organ level. For instance, AbdElgawad et al. [79] studied antioxidant enzyme activity responses in different organs (roots, young leaves, and mature leaves) of salt-stressed maize plants. More specifically, they observed that DHAR and CAT activity increased in all studied organs while APX, SOD, GR, and GST increased in roots following $\mathrm{NaCl}$ application. Antioxidant activities of tolerant (BRS Bojuru) and sensitive (BRS Pampa) rice cultivars were significantly different under salt stress, where increased SOD and CAT activities were observed only in tolerant cultivars [262]. Vighi et al. [262] reported that OsGR2, OsGR3, OsAPX3, and OsSOD3-Cu/Zn genes were the markers to differentiate between sensitive and tolerant cultivars upon salinity stress. Chung et al. [263] observed that the antioxidant-related genes GmCATs and GmAPX1 responds under salt stress conditions. Compared to the control plants GmCAT1, GmCAT2, and GmAPX1 expression was upregulated by 2- to 3-fold, 3- to 4-fold, and 8- to 9-fold, respectively, in soybean plants under salt stress. Such higher salt tolerances of tolerant cultivars are linked to higher antioxidant levels than salt-sensitive cultivars [264].

Various protectants are reported to increase the salinity-mediated oxidative stress tolerance in plants via modulating antioxidant machinery. For example, salicylic acid and Si supplementation improved salt tolerance in wheat and mung bean, respectively, by increasing APX, CAT, and SOD activities that lowered $\mathrm{H}_{2} \mathrm{O}_{2}$ levels, EL, and MDA content $[47,265]$. Rady et al. [266] reported that pretreatment with Moringa oleifera leaf extract (MLE; $6 \%$ ) better regulated both the non-enzymatic antioxidants (GSH, AsA, and AsA redox) and enzymatic antioxidants (APX, GPX, POD, SOD, and CAT) than Pro $(12 \mathrm{mM})$ pretreatment for tackling salt stress. From the above reports, it is evident that alterations in the antioxidant system impart salinity tolerance in plants.

\subsection{Metals/Metalloids Toxicity}

The tolerance mechanism of plants to metals/metalloids-induced oxidative stress depends on the antioxidant defense capacity. It is positively correlated with the enhancement of the antioxidant enzyme activities and the improved synthesis of non-enzymatic antioxidants. Apart from the role of ROS scavenging, these components, both enzymatic and non-enzymatic, also help in metal chelation to some extent [267-269].

El-Amier et al. [90] observed that P. sativum L. seedlings when exposed to $\mathrm{Ni}\left(100 \mu \mathrm{M} \mathrm{NiCl}_{2}\right.$, $72 \mathrm{~h}$ ), GSH content was increased linearly up to $48 \mathrm{~h}$ and then declined, whereas GSSG content increased up to $36 \mathrm{~h}$ and then decreased. The later reduction of GSH and GSSG contents might disrupt the antioxidative system by Ni-toxicity stress [90]. In rice seedlings, 0.25 and $0.5 \mathrm{mM} \mathrm{NiSO}_{4} .7 \mathrm{H}_{2} \mathrm{O}$ enhanced both the GSH and GSSG contents, of which GSSG was further declined. Moreover, decreased AsA and increased DHA contents and ultimately reduced AsA/DHA ratio under Ni-stress was reversed by the exogenous application of $\mathrm{Si}\left(0.05 \mathrm{mM} \mathrm{Na}_{2} \mathrm{SiO}_{3}\right)$ that signifies the ability of $\mathrm{Si}$ to upregulate the AsA-GSH cycle [87]. Nickel stress also enhanced APX, MDHAR, DHAR, GR, GPX, and SOD activities, which were further upregulated by the supplementation of Si. The LOX activity was also increased under Ni stress, but Si application reduced LOX actions [87]. Almost 3-fold higher AsA, 2-fold higher GSH, and 4.5-fold higher GSSG contents along with increased SOD and CAT activity were observed in Cajanas cajan seedlings when exposed to $10 \mu \mathrm{M}$ of $\mathrm{As}\left(\mathrm{as} \mathrm{Na}_{3} \mathrm{AsO}_{4}\right)$ for 5 days [270]. With higher levels of As stress (150 and $300 \mu \mathrm{M} \mathrm{Na}_{3} \mathrm{AsO}_{4}, 35 \mathrm{~d}$ ) increased activities of SOD, CAT and POD were reported in two different cultivars of Chenopodium quinoa, and these enzyme activities were further upregulated with dimethylthiourea $(5 \mathrm{mM})$ treatment [271].

\subsection{High Temperature}

The plants typically use antioxidant protection systems to deal with HT stress, which varies among genotypes [68,272]. Mansoor and Naqvi [273] observed the elevated activity of SOD, POD, and APX in all genotypes of mung bean (V. radiata L.) at $40{ }^{\circ} \mathrm{C}$ except CAT. Sarkar et al. [235] observed 
an increased activity of CAT, GSH, APX, and POX in all tested wheat cultivars at $30^{\circ} \mathrm{C}$. However, all these enzyme activities decreased in heat-sensitive cultivars, compared to tolerant ones at $35^{\circ} \mathrm{C}$. A similar result for enzymatic antioxidants was reported by Ding et al. [180] in cucumber (C. sativus L.) seedlings, in which the activity of SOD, CAT, APX, GR, and POD increased by 16.6, 13, 25.2, 14.4, and $35.4 \%$, respectively, under HT stress $\left(35^{\circ} \mathrm{C}\right)$, while GSH down-regulated as a non-enzymatic antioxidant. In contrast, Awasthi et al. [103] found a higher content of GSH in chickpea (Cicer arietinum L.) plants at HT stress conditions. Djanaguiraman et al. [274] reported that due to the lower activity of CAT and POX during HT stress, SOD activity decreased, and ROS toxicity increased in both pistils and pollen grains of both pearl millet and sorghum plants. However, in cabbage and kale plants, Soengas et al. [275] found a higher activity of SOD, CAT, and GR, compared to controls under HT stress $\left(32^{\circ} \mathrm{C}\right)$, while compared with cabbage, the activity of SOD recorded was higher in kale plants. In a greenhouse experiment, Sarwar et al. [104] exposed cotton plants to HT stress and treated them with growth regulators (water and $\mathrm{H}_{2} \mathrm{O}_{2}$ ). After the treatment duration, they observed that the $\mathrm{H}_{2} \mathrm{O}_{2}$ treated plants showed higher SOD $(0.75,0.33$, and 0.36 -fold) and CAT $(2.26,1.19$, and 1.31-fold) activity than plants with water under high, medium, and optimum thermal regimes, respectively.

\subsection{Low Temperature}

Numerous studies have revealed that the elevated SOD activity in plants mediates LT tolerance by scavenging $\mathrm{H}_{2} \mathrm{O}_{2}$ [109,276]. Unlike SOD, CAT and APX also catalyze the $\mathrm{H}_{2} \mathrm{O}_{2}$. Wang et al. [277] found the higher activity of CAT in indica 93-11 after $24 \mathrm{~h}$ of LT stress, while activity declined with increased stress duration. Shi et al. [278], Wani et al. [279], and Mohammadrezakhani et al. [280] observed that due to the LT stress, CAT activity increased significantly in Cynodon dactylon, Capsella bursa-pastoris, and Citrus reticulata. Whereas, higher APX activity in Jatropha macrocarpa even under high $\mathrm{H}_{2} \mathrm{O}_{2}$ levels improved LT stress resistance while J. curcas could not withstand LT condition due to the reduced ( $>6$-fold) activity of APX [281]. Cheng et al. [282] kept watermelon (Citrullus lanatus) plants at $10 / 5^{\circ} \mathrm{C}$ for 7 days and observed that GSH/GSSG and AsA/DHA ratios were increased by 30.6 and $214.3 \%$, respectively, compared to controls, which is related to antioxidant defense system activation. Han et al. [109] treated 14-day-old rice seedlings at $12{ }^{\circ} \mathrm{C}$ for 6 days and reported that the GSH and GSSG contents as well as GSH/GSSG ratio were increased significantly along with higher activities of SOD, POD, and CAT. Chen et al. [283] also reported that at $4{ }^{\circ} \mathrm{C}, \mathrm{GR}, \mathrm{DHAR}$, and MDHAR activities increased by $20.26,7.64$, and $16.60 \%$, respectively, and AsA, DHA, and GSH also increased by 12.13 , 7.89 , and $56.09 \%$, respectively, compared to controls, resulting in direct scavenging of ROS. From the above examples, it is obvious that modulation in antioxidant machinery exerts a positive impact in LT tolerance ability.

\subsection{Waterlogging/Flooding}

Several crop species exhibit survival abilities under waterlogged or flooded conditions for short or even longer durations sometimes; rice can be a good example. In addition to formation of aerenchyma and adventitious roots, plants may also exhibit the ability of modulating antioxidant defense systems to combat the waterlogging-induced oxidative damages [116]. Some cereal crops like Z. mays L., S. bicolor L., and H. vulgare L. have been shown to be damaged at the cellular level by higher LPO and ROS and further antioxidative defense response $[118,119]$. Upregulation or downregulation of these antioxidants has also been reported in G. max L. [239,240], L. esculentum [284], Sesamum indicum L. [285], and Spinacia oleracea L. [286]. da-Silva and do Amarante [184] studied WL modulated upregulation of antioxidant defense system in G. max L. and observed higher activities of APX, CAT, and SOD in stressed plants along with higher ROS and MDA accumulation. Moreover, reduced AsA with a higher DHA level indicated ROS scavenging by spending AsA [184]. Waterlogging stress also showed significant variation in SOD, CAT, and POD in B. napus L., regardless of its growing condition (pot or field), along with higher MDA [287]. Some sensitive and tolerant species of Prunus were subjected to $\mathrm{WL}$, and upregulation of antioxidants (AsA and GSH contents; CAT and POD activities) were recorded, 
which indicated the existence of ROS scavenging systems in tolerant cultivars (Prunus pseudocerasus and $P$. cerasus $\times$ P. canescens) [185].

\subsection{High Light}

While studying the impact of HL, Shengxin et al. [123] disclosed that the activity of SODs, CAT, and POD decreased in rapeseed seedlings under HL conditions. Similarly, Lu et al. [191] observed decreased POD and SOD activity due to HL stress in tomatoes. In contrast, SOD, CAT, APX, and POD activities upregulated in the moderate light treated Chl-8 rice genotype leaves than Zhefu 802 [288]. In HL stress, higher SOD and CAT activity was observed in $p g l$ rice genotype compared to Zhefu 802 [289]. Lima et al. [124] demonstrated decreased CAT activity along with upregulated APX and SOD activity in HL exposed (12 h) cashew plants. Furthermore, as total AsA content decreased by $25 \%$, the total GSH content increased by $63 \%$ in HL exposed $(12 \mathrm{~h})$ cashew plants [124]. Similarly, HL stress down-regulated APX2, DHAR1, CDS1, CDS2, and FDS2 while upregulated APX1, CAT2, and FDS1 in Arabidopsis mutant (pgr5), compared to WT (Table 2; [244]). Flavonoid biosynthesis is light-dependent. Higher light intensities stimulate the flavonoids synthesis in Passiflora suberosa L., which protects the plants from HL damage, as documented by Ni et al. [290]. Moreover, Stewart et al. [291] narrated about water-insoluble antioxidant carotenoids (the xanthophylls zeaxanthin and lutein as well as $\beta$-carotene), which maintain the higher growth rate in Lemna gibba L. even under very HL $(700 \mu \mathrm{mol}$ photons $\mathrm{m}^{-2} \mathrm{~s}^{-1}, 7 \mathrm{~d}$ ). It resulted from a combination of the decline in the chl synthesis and higher zeaxanthin accumulation, which restricted the accumulation of excessive energy from excitation.

\subsection{UV-Radiation}

Tripathi et al. [129] exposed T. aestivum L. seedlings to two levels of UV-B radiation: ambient $\left(8.6 \mathrm{~kJ} \mathrm{~m}^{-2} \mathrm{~d}^{-1}\right)$ and enhanced (ambient $\left.+2.8 \mathrm{~kJ} \mathrm{~m}^{-2} \mathrm{~d}^{-1}\right)$ resulted in upregulated CAT and GPX activity along with reduced SOD and APX activities. Such a reduction in SOD activity was also observed in A. thaliana L. (genotype rsr4-1). In contrast, genotype C24 showed increased POD, APX, and GPX activities exposed to UV-B radiation $\left(3.9 \mathrm{~kJ} \mathrm{~m}^{-2}, 4 \mathrm{~d}\right)$. UV-C radiation-induced enhancement of SOD and POD activities was also reported in G. max L. [130]. Seedlings of G. max L. grown under UV-C light with $0.284 \mathrm{~mW} \mathrm{~cm}^{-2}$ intensity $\left(20 \mathrm{~min} \mathrm{~d}^{-1}\right.$ ) resulted in enhanced activity of CAT, SOD, and POD that was further upregulated with exogenous application of AsA $\left(10 \mathrm{mg} \mathrm{L}^{-1}\right)$ [130]. In Olea europaea L. cv. Galega Vulgar plants, 23.5, and 21.7\% higher free radical scavenging capacity (ABTS) was recorded in two levels of UV-B $\left(6.5\right.$ and $\left.12.4 \mathrm{~kJ} \mathrm{~m}^{-2} \mathrm{~d}^{-1}\right)$ treatments, respectively. As a result, the levels of $\mathrm{H}_{2} \mathrm{O}_{2}$ were almost similar to control plants [190]. However, in addition to such antioxidant defense responses, some terrestrial plants have also been documented to synthesize some protective phytochemicals (e.g., AsA, hydroxycinnamates, flavonoids, vitamins, etc.) when exposed to UV-B radiation [126,292,293].

\subsection{Elevated Ozone}

Ozone causes various restrictions in plants such as visible foliage injury, early senescence of leaves, stomatal closure, and inhibition of carbon transport, et cetera. Of these, stomatal closure is considered a direct cause of the yield reduction of plants as it reduces carbon uptake/carbon fixation and ultimately induces reduction in photosynthesis. Hence, decreased transportation of fixed carbon towards edible plant parts, for example, grains result in yield reduction due to low supply of source towards sink [294]. Furthermore, $\mathrm{O}_{3}$ directly disturbs the carbon translocation in phloem from leaves to other parts such as roots or edible portions and thus has more influence on yield reduction [295]. Under such scenario, a plant's ability to withstand $\mathrm{O}_{3}$ stress can stabilize yield reductions. In this regard, antioxidants can play a vital role in regulation and detoxification of toxic ROS. The influence of $\mathrm{O}_{3}$ in regulating antioxidant activities in two rice cultivars was studied by Tammam et al. [296]. Both rice cultivars showed higher SOD and APX activity in shoots, but GR and GST activities were reduced in both shoots and roots. In a two-year study on rice cultivars with contrasting ability towards $\mathrm{O}_{3}$ stress tolerance, Wang et al. [297] demonstrated that CAT, POD, and GPX activities were decreased 
in $\mathrm{O}_{3}$ sensitive cultivars. The authors concluded that $\mathrm{O}_{3}$ tolerance improved at different growth stages via regulating antioxidant activities in tolerant cultivars. In another study, $\mathrm{O}_{3}$ exposure-induced ROS production was scavenged via regulation of antioxidant activities in wheat leaves [298].

\subsection{Soil Acidity and Alkalinity}

Both acidity and alkalinity stress altered the antioxidant defense system of plants. Uplifted APX, CAT, SOD, and POD activities under acidic $\mathrm{pH}$ were found in rice [196] and tomato [197], but Bhuyan et al. [144] found down-regulated SOD and DHAR activities while GR activity remained unchanged in wheat seedlings subjected to acidity stress. Similarly, a higher pH level (alkalinity stress) resulted in lower antioxidant enzyme activities in rice. In contrast, elevated APX, CAT, SOD, and POD activities were increased in Z. mays L. under alkaline stress. Moreover, the redox balance of AsA/DHA severely declined. Although GSH content increased, GSSG content decreased, while GPX, GST, and GR activities were also reduced [198]. Later on, Bhuyan et al. [146] observed the affect of acidity ( $\mathrm{pH}$ 4.0) and alkalinity ( $\mathrm{pH}$ 8.5)-stresses on T. aestivum L. and found decreased AsA and GSH contents, with upregulated APX, CAT, GPX, and GST activities under both acidic and alkaline-stress.

\subsection{Herbicides}

The plants can mitigate herbicide-induced toxicity by two resistance mechanisms. The first one is target-site resistance, in other words, structural modification or activity enhancement of herbicide targeted proteins. The second one is non-target site resistance, in other words, developing the herbicide detoxification system [299]. The herbicide detoxification system contained three enzymatic phases: (i) in phase I, CytP450 monooxygenases; (ii) in phase II, GSH transferases and glycosyl transferases; and (iii) in phase III, tonoplast localized ATP-binding cassette transporters, while GST showed a major role in this system [300]. Several reports proved the antioxidant defense mechanisms in plants to reduce herbicide toxicity. Glyphosate toxicity alleviated in $H$. vulgare by improving the activity of antioxidant enzyme CAT ( $80 \%$ in leaves and $46 \%$ in roots), APX (106\% in leaves and $97 \%$ in roots), and GST (61\% in leaves and 95\% in roots) [162]. The activity of SOD, POD, CAT, and APX improved in Salvinia natans, which reduced glyphosate-induced oxidative stress [201]. In T. aestivum, Hasanuzzaman et al. [164] reported increased enzymatic antioxidant activities; and AsA and GSH contents to mitigate paraquat toxicity. Higher GSH content and high CAT, APX, GST, and GR activities were also observed to improve antioxidant defense in imazapic-induced Nicotiana tabacum [203].

\section{Conclusions}

It is well established that ROS play a vital role in regulating various responses under both biotic and abiotic stresses in plants. The domain of plant stress is quite vast, and the number of studies grew dramatically over the last 20 years. The interesting phenomenon among all these studies is the dual role of ROS in plants. Firstly, they are unavoidable toxic metabolic by-products; and secondly, they play signaling roles during stress conditions. Although it seems that ROS are damage causing agents in plants, their importance for stimulating the stress signaling component to stop further losses is also notable. Even with the continuous increase of stress-related publications, there exists quite little novelty in the information. Most reports just confirmed the previous results rather than bringing new insights into this domain. Therefore, there should be attempts at new approaches for obtaining the novel aspects regarding ROS metabolism. It is still an open question of how plants feel stressed and get ready for upcoming stress threats. Due to their highly reactive nature and short half-life, further research is needed on ROS chemistry and metabolism. For instance, different aspects related to ROS metabolism regulation, particularly under multiple environmental stresses, which remain unanswered. Therefore, future studies should focus on more polished techniques such as advanced imaging techniques, fluorescence in situ hybridization (FISH), advanced functional genomics, metabolomics, and proteomics to better understand the ROS metabolism in crop plants. Exogenous 
ROS application at proper dose and duration to improve signaling cascades and subsequent stress tolerance also warrants further research.

Author Contributions: Conceptualization, M.H. and M.F., writing—original draft preparation, M.H., M.H.M.B.B. K.P., T.F.B., T.I.A., K.N., M.S.H., F.Z., and M.M.A.; writing-review and editing, M.H., M.H.M.B.B., M.F., and K.N.; All authors have read and agreed to the published version of the manuscript.

Funding: This research received no external funding.

Acknowledgments: We acknowledge Sayed Mohammad Mohsin for his help in collecting literature and some artworks.

Conflicts of Interest: The authors declare no conflict of interest.

\section{References}

1. Fujimori, S.; Hasegawa, T.; Krey, V.; Riahi, K.; Bertram, C.; Bodirsky, B.L.; Bosetti, V.; Callen, J.; Després, J.; Doelman, J.; et al. A multi-model assessment of food security implications of climate change mitigation. Nat. Sustain. 2019, 2, 386-396. [CrossRef]

2. Anderson, K.; Broderick, J.F.; Stoddard, I. A factor of two: How the mitigation plans of 'climate progressive' nations fall far short of Paris-compliant pathways. Clim. Policy 2020. [CrossRef]

3. Wang, Q.J.; Sun, H.; Dong, Q.L.; Sun, T.Y.; Jin, Z.X.; Hao, Y.J.; Yao, Y.X. The enhancement of tolerance to salt and cold stresses by modifying the redox state and salicylic acid content via the cytosolic malate dehydrogenase gene in transgenic apple plants. Plant Biotechnol. J. 2016, 14, 1986-1997. [CrossRef]

4. Zhu, J. Abiotic stress signaling and responses in plants. Cell 2016, 167, 313-324. [CrossRef]

5. Mittler, R. ROS are good. Trends Plant Sci. 2017, 22, 11-19. [CrossRef] [PubMed]

6. Soares, C.; Carvalho, M.E.; Azevedo, R.A.; Fidalgo, F. Plants facing oxidative challenges-A little help from the antioxidant networks. Environ. Exp. Bot. 2019, 161, 4-25. [CrossRef]

7. Xie, X.; He, Z.; Chen, N.; Tang, Z.; Wang, Q.; Cai, Y. The roles of environmental factors in regulation of oxidative stress in plant. Biomed Res. Int. 2019, 11, 9732325. [CrossRef]

8. Foyer, C.H.; Noctor, G. Oxidant and antioxidant signaling in plants: A re-evaluation of the concept of oxidative stress in a physiological context. Plant Cell Environ. 2005, 29, 1056-1071. [CrossRef]

9. Huang, H.; Ullah, F.; Zhou, D.X.; Yi, M.; Zhao, Y. Mechanisms of ROS regulation of plant development and stress responses. Front. Plant Sci. 2019, 10, 800. [CrossRef]

10. Liebthal, M.; Maynard, D.; Dietz, K. Peroxiredoxins and redox signaling in plants. Antioxid. Redox Signal. 2018, 28, 609-624. [CrossRef] [PubMed]

11. Dangl, J.L.; Jones, J.D.G. Plant pathogens and integrated defense responses to infection. Nature 2001, 411, 826-833. [CrossRef] [PubMed]

12. Choudhury, F.K.; Rivero, R.M.; Blumwald, E.; Mittler, R. Reactive oxygen species, abiotic stress and stress combination. Plant J. 2017, 90, 856-867. [CrossRef] [PubMed]

13. Waszczak, C.; Carmody, M.; Kangasjärvi, J. Reactive oxygen species in plant signaling. Ann. Rev. Plant Biol. 2018, 69, 209-236. [CrossRef] [PubMed]

14. Huihui, Z.; Xin, L.; Zisong, X.; Yue, W.; Zhiyuan, T.; Meijun, A.; Yuehui, Z.; Wenxu, Z.; Nan, X.; Guangyu, S. Toxic effects of heavy metals $\mathrm{Pb}$ and $\mathrm{Cd}$ on mulberry (Morus alba $\mathrm{L}$.) seedling leaves: Photosynthetic function and reactive oxygen species (ROS) metabolism responses. Ecotoxicol. Environ. Saf. 2020, 195, 110469. [CrossRef] [PubMed]

15. Maurya, A.K. Oxidative stress in crop plants. In Agronomic Crops; Hasanuzzaman, M., Ed.; Springer: Singapore, 2020; pp. 349-380.

16. Hasanuzzaman, M.; Bhuyan, M.H.M.B.; Zulfiqar, F.; Raza, A.; Mohsin, S.M.; Mahmud, J.A.; Fujita, M.; Fotopoulos, V. Reactive oxygen species and antioxidant defense in plants under abiotic stress: Revisiting the crucial role of a universal defense regulator. Antioxidants 2020, 9, 681. [CrossRef] [PubMed]

17. Krumova, K.; Cosa, G. Overview of reactive oxygen species. In Singlet Oxygen: Applications in Biosciences and Nanosciences; Nonell, S., Flors, C., Eds.; The Royal Society of Chemistry: Cambridge, UK, 2016; pp. 1-21.

18. Bienert, G.P.; Møller, A.L.B.; Kristiansen, K.A.; Schulz, A.; Møller, I.M.; Schjoerring, J.K.; Jahn, T.P. Specific aquaporins facilitate the diffusion of hydrogen peroxide across membranes. J. Biol. Chem. 2007, 282, 1183-1192. [CrossRef] [PubMed] 
19. Quan, L.J.; Zhang, B.; Shi, W.W.; Li, H.Y. Hydrogen peroxide in plants: A versatile molecule of the reactive oxygen species network. J. Integrat. Plant Biol. 2008, 50, 2-18. [CrossRef]

20. Gill, S.S.; Tuteja, N. Reactive oxygen species and antioxidant machinery in abiotic stress tolerance in crop plants. Plant Physiol. Biochem. 2010, 48, 909-930. [CrossRef]

21. Miller, G.; Schlauch, K.; Tam, R.; Cortes, D.; Torres, M.A.; Shulaev, V.; Dangl, J.L.; Mittler, R. The plant NADPH oxidase RBOHD mediates rapid systemic signaling in response to diverse stimuli. Sci. Signal. 2009, 2, ra45. [CrossRef]

22. Mittler, R.; Vanderauwera, S.; Suzuki, N.; Miller, G.; Tognetti, V.B.; Vandepoele, K.; Gollery, M.; Shulaev, V.; Van Breusegem, F. ROS signaling: The new wave? Trends Plant Sci. 2011, 16, 300-309. [CrossRef]

23. Dietz, K.J.; Turkan, I.; Krieger-Liszkay, A. Redox- and reactive oxygen species-dependent signaling in and from the photosynthesizing chloroplast. Plant. Physiol. 2016, 171, 1541-1550. [CrossRef] [PubMed]

24. Raja, V.; Majeed, U.; Kang, H.; Andrabi, K.I.; John, R. Abiotic stress: Interplay between ROS, hormones and MAPKs. Environ. Exp. Bot. 2017, 137, 142-157. [CrossRef]

25. Suzuki, N.; Koussevitzky, S.; Mittler, R.; Miller, G. ROS and redox signaling in the response of plants to abiotic stress. Plant Cell Environ. 2012, 35, 259-270. [CrossRef] [PubMed]

26. Bose, J.; Rodrigo-Moreno, A.; Shabala, S. ROS homeostasis in halophytes in the context of salinity stress tolerance. J. Exp. Bot. 2014, 65, 1241-1257. [CrossRef]

27. Singh, A.; Kumar, A.; Yadav, S.; Singh, I.K. Reactive oxygen species-mediated signaling during abiotic stress. Plant Gene 2019, 18, 100-173. [CrossRef]

28. Laloi, C.; Apel, K.; Danon, A. Reactive oxygen signalling: The latest news. Curr. Opin. Plant Biol. 2004, 7, $323-328$. [CrossRef]

29. Mignolet-Spruyt, L.; Xu, E.; Idanheimo, N.; Hoeberichts, F.A.; Muhlenbock, P.; Brosche, M.; Van Breusegem, F.; Kangasjarvi, J. Spreading the news: Subcellular and organellar reactive oxygen species production and signalling. J. Exp. Bot. 2016, 67, 3831-3844. [CrossRef]

30. Kerchev, P.; Waszczak, C.; Lewandowska, A.; Willems, P.; Shapiguzov, A.; Li, Z. Lack of GLYCOLATE OXIDASE1, but not GLYCOLATE OXIDASE2, attenuates the photorespiratory phenotype of CATALASE2deficient Arabidopsis. Plant. Physiol. 2016, 171, 1704-1719. [CrossRef]

31. Del Río, L.A.; López-Huertas, E. ROS generation in peroxisomes and its role in cell signaling. Plant Cell Physiol. 2016, 57, 1364-1376. [CrossRef]

32. Noctor, G.; Veljovic-Jovanovic, S.; Driscoll, S.; Novitskaya, L.; Foyer, C. Drought and oxidative load in the leaves of C3 plants: A predominant role for photorespiration? Ann. Bot. 2002, 89, 841-850. [CrossRef]

33. Gilroy, S.; Białasek, M.; Suzuki, N.; Górecka, M.; Devireddy, A.R.; Karpinski, S. ROS, calcium, and electric signals: Key mediators of rapid systemic signaling in plants. Plant Physiol. 2016, 171, 1606-1615. [CrossRef]

34. Turrens, J.F. Mitochondrial formation of reactive oxygen species. J. Physiol. 2003, 552, 335-344. [CrossRef] [PubMed]

35. Steffens, B. The role of ethylene and ROS in salinity, heavy metal, and flooding responses in rice. Front. Plant Sci. 2014, 5, 685. [CrossRef] [PubMed]

36. Huang, S.; VanAken, O.; Schwarzländer, M.; Belt, K.; Millar, A.H. The roles of mitochondrial reactive oxygen species in cellular signaling and stress responses in plants. Plant. Physiol. 2016, 171, 1551-1559. [CrossRef] [PubMed]

37. Kärkönen, A.; Kuchitsu, K. Reactive oxygen species in cell wall metabolism and development in plants. Phytochemistry 2015, 112, 22-32. [CrossRef] [PubMed]

38. Skirycz, A.; Inzé, D. More from less: Plant growth under limited water. Curr. Opin. Biotechnol. 2010, 212, 197-203. [CrossRef] [PubMed]

39. Tenhaken, R. Cell wall remodeling under abiotic stress. Front. Plant Sci. 2015, 5, 771. [CrossRef]

40. Sharma, P.; Jha, A.B.; Dubey, R.S.; Pessarakli, M. Reactive oxygen species, oxidative damage, and antioxidative defense mechanism in plants under stressful conditions. J. Bot. 2012, 217037. [CrossRef]

41. Karuppanapandian, T.; Moon, J.C.; Kim, C.; Manoharan, K.; Kim, W. Reactive oxygen species in plants: Their generation, signal transduction, and scavenging mechanisms. Aust. J. Crop Sci. 2011, 5, 709.

42. Heyno, E.; Mary, V.; Schopfer, P.; Krieger-Liszkay, A. Oxygen activation at the plasma membrane: Relation between superoxide and hydroxyl radical production by isolated membranes. Planta 2011, 234, 35-45. [CrossRef] 
43. Janků, M.; Luhová, L.; Petřivalský, M. On the origin and fate of reactive oxygen species in plant cell compartments. Antioxidants 2019, 8, 105. [CrossRef] [PubMed]

44. Kumar, J.S.P.; Prasad, R.S.; Banerjee, R.; Thammineni, C. Seed birth to death: Dual functions of reactive oxygen species in seed physiology. Ann. Bot. 2015, 116, 663-668. [CrossRef] [PubMed]

45. Yesbergenova, Z.; Yang, G.; Oron, E.; Soer, D.; Fluhr, R.; Sagi, M. The plant Mo-hydroxylases aldehyde oxidase and xanthine dehydrogenase have distinct reactive oxygen species signatures and are induced by drought and abscisic acid. Plant J. 2005, 42, 862-876. [CrossRef] [PubMed]

46. Hasanuzzaman, M.; Bhuyan, M.H.M.B.; Anee, T.I.; Parvin, K.; Nahar, K.; Mahmud, J.A.; Fujita, M. Regulation of ascorbate-glutathione pathway in mitigating oxidative damage in plants under abiotic stress. Antioxidants 2019, 8, 384. [CrossRef] [PubMed]

47. Ahmad, P.; Ahanger, M.A.; Alam, P.; Alyemeni, M.N.; Wijaya, L.; Ali, S.; Ashraf, M. Silicon (Si) supplementation alleviates $\mathrm{NaCl}$ toxicity in mung bean [Vigna radiata (L.) Wilczek] through the modifications of physio-biochemical attributes and key antioxidant enzymes. J. Plant Growth Regul. 2019, 38, 70-82. [CrossRef]

48. Anjum, N.A.; Sofo, A.; Scopa, A. Lipids and proteins-Major targets of oxidative modifications in abiotic stressed plants. Environ. Sci. Pollut. Res. 2015, 22, 4099-4121. [CrossRef]

49. Demidchik, V. Mechanisms of oxidative stress in plants: From classical chemistry to cell biology. Environ. Expt. Bot. 2015, 109, 212-228. [CrossRef]

50. Catalá, A. An overview of lipid peroxidation with emphasis in outer segments of photoreceptors and the chemilumin escence assay. Int. J. Biochem. Cell Biol. 2006, 38, 1482-1495. [CrossRef]

51. Farmer, E.E.; Mueller, M.J. ROS-mediated lipid peroxidation and RES-activated signaling. Annu. Rev. Plant Biol. 2013, 64, 429-450. [CrossRef]

52. Banerjee, A.; Roychoudhury, A. Abiotic stress, generation of reactive oxygen species, and their consequences: An overview. In Reactive Oxygen Species in Plants: Boon or Bane-Revisiting the Role of ROS; Singh, V.P., Singh, S., Tripathi, D.K., Prasad, S.M., Chauhan, D.K., Eds.; John Wiley \& Sons Ltd.: Chichester, UK, 2018; pp. $23-50$.

53. Møller, I.M.; Jensen, P.E.; Hansson, A. Oxidative modifications to cellular components in plants. Annu. Rev. Plant Biol. 2007, 58, 459-481. [CrossRef]

54. Onda, Y. Oxidative protein-folding systems in plant cells. Int. J. Cell Biol. 2013, 585431. [CrossRef] [PubMed]

55. Kale, R.; Hebert, A.E.; Frankel, L.K.; Sallans, L.; Bricker, T.M.; Pospíšil, P. Amino acid oxidation of the D1 and D2 proteins by oxygen radicals during photoinhibition of Photosystem II. Proc. Natl. Acad. Sci. USA 2017, 114, 2988-2993. [CrossRef] [PubMed]

56. Sharma, J.; Panico, M.; Shipton, C.A.; Nilsson, F.; Morris, H.R.; Barber, J. Primary structure characterization of the photosystem II D1 and D2 subunits. J. Biol. Chem. 1997, 272, 33158-33166. [CrossRef] [PubMed]

57. Frankel, L.K.; Sallans, L.; Limbach, P.A.; Bricker, T.M. Identification of oxidized amino acid residues in the vicinity of the $\mathrm{Mn}_{(4)} \mathrm{CaO}_{(5)}$ cluster of Photosystem II: Implications for the identification of oxygen channels within the Photosystem. Biochemistry 2012, 51, 6371-6377. [CrossRef]

58. Frankel, L.K.; Sallans, L.; Limbach, P.A.; Bricker, T.M. Oxidized amino acid residues in the vicinity of $Q_{(A)}$ and $\mathrm{Pheo}_{(\mathrm{D} 1)}$ of the photosystem II reaction center: Putative generation sites of reducing-side reactive oxygen species. PLoS ONE 2013, 8, e58042. [CrossRef]

59. Saha, P.; Mukherjee, A.; Biswas, A.K. Modulation of $\mathrm{NaCl}$ induced DNA damage and oxidative stress in mungbean by pretreatment with sublethal dose. Biol. Plant 2015, 59, 139-146. [CrossRef]

60. Lin, A.-J.; Zhang, X.-H.; Chen, M.-M.; Cao, Q. Oxidative stress and DNA damages induced by cadmium accumulation. J. Environ. Sci. 2007, 19, 596-602. [CrossRef]

61. Choudhury, S.; Panda, P.; Sahoo, L.; Panda, S.K. Reactive oxygen species signaling in plants under abiotic stress. Plant Signal. Behav. 2013, 8, e23681. [CrossRef]

62. Marnett, L.J. Oxyradicals and DNA damage. Carcinogenesis 2000, 21, 361-370. [CrossRef]

63. Lehmann, M.; Laxa, M.; Sweetlove, L.J.; Fernie, A.R.; Obata, T. Metabolic recovery of Arabidopsis thaliana roots following cessation of oxidative stress. Metabolomics 2012, 8, 143-153. [CrossRef]

64. Dumont, S.; Rivoal, J. Consequences of oxidative stress on plant glycolytic and respiratory metabolism. Front. Plant Sci. 2019, 10, 166. [CrossRef] [PubMed]

65. Fahad, S.; Bajwa, A.A.; Nazir, U.; Anjum, S.A.; Farooq, A.; Zohaib, A.; Sadia, S.; Nasim, W.; Adkins, S.; Saud, S.; et al. Crop production under drought and heat stress: Plant responses and management options. Front. Plant Sci. 2017, 8, 1147. [CrossRef] [PubMed] 
66. Hasanuzzaman, M.; Nahar, K.; Anee, T.I.; Khan, M.I.R.; Fujita, M. Silicon-mediated regulation of antioxidant defense and glyoxalase systems confers drought stress tolerance in Brassica napus L. S. Afr. J. Bot. 2018, 115, 50-57. [CrossRef]

67. Uzildaya, B.; Turkana, I.; Sekmena, A.H.; Ozgura, R.; Karakayab, H.C. Comparison of ROS formation and antioxidant enzymes in Cleome gynandra (C4) and Cleome spinosa (C3) under drought stress. Plant Sci. 2012, 182, 59-70. [CrossRef]

68. Hasanuzzaman, M.; Hossain, M.A.; Teixeira da Silva, J.A.; Fujita, M. Plant responses and tolerance to abiotic oxidative stress: Antioxidant defense is a key factor. In Crop Stress and its Management: Perspectives and Strategies; Bandi, V., Shanker, A.K., Shanker, C., Mandapaka, M., Eds.; Springer: Berlin, Germany, 2012; pp. 261-316.

69. Nahar, K.; Hasanuzzaman, M.; Alam, M.; Rahman, A.; Mahmud, J.A.; Suzuki, T.; Fujita, M. Insights into spermine-induced combined high temperature and drought tolerance in mung bean: Osmoregulation and roles of antioxidant and glyoxalase system. Protoplasma 2017, 254, 445-460. [CrossRef]

70. Hasanuzzaman, M.; Nahar, K.; Hossain, M.S.; Anee, T.I.; Parvin, K.; Fujita, M. Nitric oxide pretreatment enhances antioxidant defense and glyoxalase systems to confer PEG-induced oxidative stress in rapeseed. J. Plant Interact. 2017, 12, 323-331. [CrossRef]

71. Nahar, S.; Vemireddy, L.R.; Sahoo, L.; Tanti, B. Antioxidant protection mechanisms reveal significant response in drought-induced oxidative stress in some traditional rice of Assam, India. Rice Sci. 2018, 25, 185-196. [CrossRef]

72. Sarker, U.; Oba, S. Drought stress effects on growth, ROS markers, compatible solutes, phenolics, flavonoids, and antioxidant activity in Amaranthus tricolor. Appl. Biochem. Biotechnol. 2018, 186, 999-1016. [CrossRef]

73. Rezayian, M.; Ebrahimzadeh, H.; Niknam, V. Nitric oxide stimulates antioxidant system and osmotic adjustment in soybean under drought stress. J. Soil. Sci. Plant. Nutr. 2020, 16, 1-11. [CrossRef]

74. Abbas, T.; Rizwan, M.; Ali, S.; Adrees, M.; Mahmood, A.; Zia-ur-Rehman, M.; Ibrahim, M.; Arshad, M.; Qayyum, M.F. Biochar application increased the growth and yield and reduced cadmium in drought stressed wheat grown in an aged contaminated soil. Ecotoxicol. Environ. Saf. 2018, 148, 825-833. [CrossRef]

75. Hussain, H.A.; Men, S.; Hussain, S.; Chen, Y.; Ali, S.; Zhang, S.; Zhang, K.; Li, Y.; Xu, Q.; Liao, C.; et al. Interactive effects of drought and heat stresses on morpho-physiological attributes, yield, nutrient uptake and oxidative status in maize hybrids. Sci. Rep. 2019, 9, 1-12. [CrossRef] [PubMed]

76. Liu, J.; Hasanuzzaman, M.; Wen, H.; Zhang, J.; Peng, T.; Sun, H.; Zhao, Q. High temperature and drought stress cause abscisic acid and reactive oxygen species accumulation and suppress seed germination growth in rice. Protoplasma 2019, 256, 1217-1227. [CrossRef] [PubMed]

77. Singh, D.; Singh, C.K.; Taunk, J.; Tomar, R.S.S.; Chaturvedi, A.K.; Gaikwad, K.; Pal, M. Transcriptome analysis of lentil (Lens culinaris Medikus) in response to seedling drought stress. BMC Genom. 2017, 18, 206. [CrossRef] [PubMed]

78. Chawla, S.; Jain, S.; Jain, V. Salinity induced oxidative stress and antioxidant system in salt-tolerant and salt-sensitive cultivars of rice (Oryza sativa L.). J. Plant Biochem. Biotechnol. 2013, 22, 27-34. [CrossRef]

79. AbdElgawad, H.; Zinta, G.; Hegab, M.M.; Pandey, R.; Asard, H.; Abuelsoud, W. High salinity induces different oxidative stress and antioxidant responses in maize seedlings organs. Front. Plant. Sci. 2016, 7, 276. [CrossRef]

80. Siddiqui, M.N.; Mostofa, M.G.; Akter, M.M.; Srivastava, A.K.; Sayed, M.A.; Hasan, M.S.; Tran, L.S.P. Impact of salt-induced toxicity on growth and yield-potential of local wheat cultivars: Oxidative stress and ion toxicity are among the major determinants of salt-tolerant capacity. Chemosphere 2017, 187, 385-394. [CrossRef]

81. Cheng, Y.-W.; Kong, X.-W.; Wang, N.; Wang, T.-T.; Chen, J.; Shi, Z.Q. Thymol confers tolerance to salt stress by activating anti-oxidative defense and modulating $\mathrm{Na}^{+}$homeostasis in rice root. Ecotoxicol. Environ. Saf. 2020, 188, 109894. [CrossRef]

82. Ahanger, M.A.; Mir, R.A.; Alyemeni, M.N.; Ahmad, P. Combined effects of brassinosteroid and kinetin mitigates salinity stress in tomato through the modulation of antioxidant and osmolyte metabolism. Plant Physiol. Biochem. 2020, 147, 31-42. [CrossRef]

83. Nahar, K.; Rahman, M.; Hasanuzzaman, M.; Alam, M.M.; Rahman, A.; Suzuki, T.; Fujita, M. Physiological and biochemical mechanisms of spermine-induced cadmium stress tolerance in mung bean (Vigna radiata L.) seedlings. Environ. Sci. Pollut. Res. 2016, 23, 21206-21218. [CrossRef] 
84. Nahar, K.; Hasanuzzaman, M.; Suzuki, T.; Fujita, M. Polyamines-induced aluminum tolerance in mung bean: A study on antioxidant defense and methylglyoxal detoxification systems. Ecotoxicology 2017, 26, 58-73. [CrossRef]

85. Hasanuzzaman, M.; Nahar, K.; Anee, T.I.; Fujita, M. Exogenous silicon attenuates cadmium-induced oxidative stress in Brassica napus L. by modulating AsA-GSH pathway and glyoxalase system. Front. Plant Sci. 2017, 8, 1061. [CrossRef] [PubMed]

86. Hasanuzzaman, M.; Nahar, K.; Rahman, A.; Mahmud, J.A.; Alharby, H.F.; Fujita, M. Exogenous glutathione attenuates lead-induced oxidative stress in wheat by improving antioxidant defense and physiological mechanisms. J. Plant Interact. 2018, 13, 203-212. [CrossRef]

87. Hasanuzzaman, M.; Alam, M.M.; Nahar, K.; Mohsin, S.M.; Bhuyan, M.H.M.B.; Parvin, K.; Hawrylak-Nowak, B.; Fujita, M. Silicon-induced antioxidant defense and methylglyoxal detoxification works coordinately in alleviating nickel toxicity in Oryza sativa L. Ecotoxicology 2019, 28, 261-276. [CrossRef]

88. Mahmud, J.A.; Hasanuzzaman, M.; Nahar, K.; Rahman, A.; Hossain, M.S.; Fujita, M. Maleic acid assisted improvement of metal chelation and antioxidant metabolism confers chromium tolerance in Brassica juncea $\mathrm{L}$. Ecotoxicol. Environ. Saf. 2017, 144, 216-226. [CrossRef] [PubMed]

89. Mahmud, J.A.; Hasanuzzaman, M.; Nahar, K.; Bhuyan, M.H.M.B.; Fujita, M. Insights into citric acid-induced cadmium tolerance and phytoremediation in Brassica juncea L.: Coordinated functions of metal chelation, antioxidant defense and glyoxalase systems. Ecotoxicol. Environ. Saf. 2018, 147, 990-1001. [CrossRef] [PubMed]

90. El-Amier, Y.; Elhindi, K.; El-Hendawy, S.; Al-Rashed, S.; Abd-ElGawad, A. Antioxidant system and biomolecules alteration in Pisum sativum under heavy metal stress and possible alleviation by 5-aminolevulinic acid. Molecules 2019, 24, 4194. [CrossRef]

91. Gupta, D.; Pena, L.B.; Romero-Puertas, M.C.; Hernández, A.; Inouhe, M.; Sandalio, L.M. NADPH oxidases differentially regulate ROS metabolism and nutrient uptake under cadmium toxicity. Plant Cell Environ. 2017, 40, 509-526. [CrossRef] [PubMed]

92. Kabała, K.; Zboinska, M.; Głowiak, D.; Reda, M.; Jakubowska, D.; Janicka, M. Interaction between the signaling molecules hydrogen sulfide and hydrogen peroxide and their role in vacuolar $\mathrm{H}^{+}$-ATPase regulation in cadmium-stressed cucumber roots. Physiol. Plant. 2019, 166, 688-704. [CrossRef]

93. Mathur, S.; Agrawal, D.; Jajoo, A. Photosynthesis: Limitations in response to high temperature stress. J. Photochem. Photobiol. B Biol. 2014, 137, 116-126. [CrossRef]

94. Onaga, G.; Wydra, K. Advances in plant tolerance to abiotic stresses. In Plant Genomics; Abdurakhmonov, I.Y., Ed.; InTech: Rijeka, Croatia, 2016. [CrossRef]

95. Pospíšil, P. Production of reactive oxygen species by photosystem II as a response to light and temperature stress. Front. Plant Sci. 2016, 26, 1950. [CrossRef]

96. Yamashita, A.; Nijo, N.; Pospisil, P.; Morita, N.; Takenaka, D.; Aminaka, R.; Yamamoto, Y.; Yamamoto, Y. Quality control of photosystem II: Reactive oxygen species are responsible for the damage to photosystem II under moderate heat stress. J. Biol. Chem. 2008, 283, 28380-28391. [CrossRef] [PubMed]

97. Mattila, H.; Mishra, K.B.; Kuusisto, I.; Mishra, A.; Novotná, K.; Šebela, D.; Tyystjärvi, E. Effects of low temperature on photoinhibition and singlet oxygen production in four natural accessions of Arabidopsis. Planta 2020, 252, 19. [CrossRef] [PubMed]

98. Shimakawa, G.; Miyake, C. What quantity of photosystem I is optimum for safe photosynthesis? Plant Physiol. 2019, 179, 1479-1485. [CrossRef] [PubMed]

99. Li, Q.; Wang, W.; Wang, W.; Zhang, G.; Liu, Y.; Wang, Y.; Wang, W. Wheat F-box protein gene TaFBA1 is involved in plant tolerance to heat stress. Front. Plant Sci. 2018, 9, 521. [CrossRef]

100. Zhang, K.; Chen, B.; Hao, Y.; Yang, R.; Wang, Y. Effects of short-term heat stress on PSII and subsequent recovery for senescent leaves of Vitis vinifera L. cv. Red Globe. J. Integr. Agric. 2018, 17, 2683-2693. [CrossRef]

101. Fahad, S.; Hussain, S.; Saud, S.; Khan, F.; Hassan, S.; Amanullah, J.; Jatoi, W.N.; Arif, M.; Wang, F.; Huang, J. Exogenously applied plant growth regulators affect heat-stressed rice pollens. J. Agron. Crop Sci. 2016, 202, 139-150. [CrossRef]

102. Jin, R.; Wang, Y.; Liu, R.; Gou, J.; Chan, Z. Physiological and metabolic changes of purslane (Portulaca oleracea L.) in response to drought, heat, and combined stresses. Front. Plant Sci. 2015, 6, 1123. [CrossRef] 
103. Awasthi, R.; Gaur, P.; Turner, N.C.; Vadez, V.; Siddique, K.H.M.; Nayyar, H. Effects of individual and combined heat and drought stress during seed filling on the oxidative metabolism and yield of chickpea (Cicer arietinum) genotypes differing in heat and drought tolerance. Crop Past. Sci. 2017, 68, 823-841. [CrossRef]

104. Sarwar, M.; Saleem, M.F.; Ullah, N.; Rizwan, M.; Ali, S.; Shahid, M.R.; Alamri, S.; Alyemen, M.N.; Ahmad, P. Exogenously applied growth regulators protect the cotton crop from heat-induced injury by modulating plant defense mechanism. Sci. Rep. 2018, 8, 1-15. [CrossRef]

105. Guo, Y.; Liu, S.; Yang, Z.; Tian, S.; Sui, N. Responses of unsaturated fatty acid in membrane lipid and antioxidant enzymes to chilling stress in sweet sorghum (Sorghum bicolor L. Moench) seedling. J. Agric. Sci. 2016, 8, 71. [CrossRef]

106. Zhang, J.Y.; Luo, W.; Zhao, Y.; Xu, Y.Y.; Song, S.H.; Chong, K. Comparative metabolomic analysis reveals a reactive oxygen species-dominated dynamic model underlying chilling environment adaptation and tolerance in rice. New Phytol. 2016, 211, 1295-1310. [CrossRef]

107. Diao, Q.; Song, Y.; Shi, D.; Qi, H. Interaction of Polyamines, Abscisic Acid, Nitric Oxide, and Hydrogen Peroxide under Chilling Stress in Tomato (Lycopersicon esculentum Mill.) Seedlings. Front. Plant Sci. 2017, 8, 203. [CrossRef] [PubMed]

108. Ghanbari, F.; Sayyari, M. Controlled drought stress affects the chilling-hardening capacity of tomato seedlings as indicated by changes in phenol metabolisms, antioxidant enzymes activity, osmolytes concentration and abscisic acid accumulation. Sci. Hortic. 2018, 229, 167-174. [CrossRef]

109. Han, Q.H.; Huang, B.; Ding, C.B.; Zhang, Z.W.; Chen, Y.E.; Hu, C.; Zhou, L.J.; Huang, Y.; Liao, J.Q.; Yuan, S.; et al. Effects of melatonin on anti-oxidative systems and photosystem II in cold-stressed rice seedlings. Front. Plant Sci. 2017, 8, 785. [CrossRef]

110. Jan, N.; Majeed, U.; Andrabi, K.I.; John, R. Cold stress modulates osmolytes and antioxidant system in Calendula officinalis. Acta Physiol. Plant. 2018, 40, 73. [CrossRef]

111. Hsu, C.H.; Hsu, Y.T. Biochemical responses of rice roots to cold stress. Bot. Stud. 2019, 60, 14. [CrossRef] [PubMed]

112. Bailey-Serres, J.; Voesenek, L.A.C.J. Flooding stress: Acclimations and genetic diversity. Annu. Rev. Plant Biol. 2008, 59, 313-339. [CrossRef] [PubMed]

113. Hasanuzzaman, M.; Mahmud, J.A.; Nahar, K.; Anee, T.I.; Inafuku, M.; Oku, H.; Fujita, M. Responses, adaptation, and ROS metabolism in plants exposed to waterlogging stress. In Reactive Oxygen Species and Antioxidant Systems in Plants: Role and Regulation under Abiotic Stress; Khan, M.I.R., Khan, N.A., Eds.; Springer Nature: Singapore, 2017; pp. 257-281.

114. Fiedler, S.; Vepraskas, M.J.; Richardson, J.L. Soil redox potential: Importance, field measurements, and observations. Adv. Agron. 2007, 94, 2-56.

115. Wegner, L.H. Oxygen transport in waterlogged plants. In Waterlogging Signalling and Tolerance in Plants; Mancuso, S., Shabala, S., Eds.; Springer: Berlin, Germany, 2010; pp. 3-22.

116. Ashraf, M.A. Waterlogging stress in plants: A review. Afr. J. Agric. Res. 2012, 7, 1976-1981.

117. Li, W.; Mo, W.; Ashraf, U.; Li, G.; Wen, T.; Abrar, M.; Gao, L.; Liu, J.; Hu, J. Evaluation of physiological indices of waterlogging tolerance of different maize varieties in South China. App. Ecol. Environ. Res. 2018, 16, $2059-2072$. [CrossRef]

118. Luan, H.; Shen, H.; Pan, Y.; Guo, B.; Lv, C.; Xu, R. Elucidating the hypoxic stress response in barley (Hordeum vulgare L.) during waterlogging: A proteomics approach. Sci. Rep. 2018, 8, 9655. [CrossRef] [PubMed]

119. Salah, A.; Zhan, M.; Cao, C.; Han, Y.; Ling, L.; Liu, Z.; Li, P.; Ye, M.; Jiang, Y. $\gamma$-aminobutyric acid promotes chloroplast ultrastructure, antioxidant capacity, and growth of waterlogged maize seedlings. Sci. Rep. 2019, 9, 484. [CrossRef] [PubMed]

120. Nishiyama, Y.; Allakhverdiev, S.I.; Murata, N. Protein synthesis is the primary target of reactive oxygen species in the photoinhibition of photosystem II. Physiol. Plant. 2011, 142, 35-46. [CrossRef] [PubMed]

121. Awad, J.; Stotz, H.U.; Fekete, A.; Krischke, M.; Engert, C.; Havaux, M.; Berger, S.; Mueller, M.J. 2-cysteine peroxiredoxins and thylakoid ascorbate peroxidase create a water-water cycle that is essential to protect the photosynthetic apparatus under high light stress conditions. Plant Physiol. 2015, 167, 1592-1603. [CrossRef] [PubMed] 
122. Vuleta, A.; Manitašević Jovanović, S.; Tucić, B. Adaptive flexibility of enzymatic antioxidants SOD, APX and CAT to high light stress: The clonal perennial monocot Iris pumila as a study case. Plant. Physiol. Biochem. 2016, 100, 166-173. [CrossRef]

123. Shengxin, C.; Chunxia, L.; Xuyang, Y.; Song, C.; Xuelei, J.; Xiaoying, L.; Zhigang, X.; Rongzhan, G. Morphological, photosynthetic, and physiological responses of rapeseed leaf to different combinations of red and blue lights at the rosette stage. Front. Plant Sci. 2016, 7, 1144. [CrossRef]

124. Lima, C.S.; Ferreira-Silva, S.L.; Carvalho, F.E.L.; Lima Neto, M.C.; Aragão, R.M.; Silva, E.N.; Sousa, R.M.J.; Silveira, J.A.G. Antioxidant protection and PSII regulation mitigate photo-oxidative stress induced by drought followed by high light in cashew plants. Environ. Exp. Bot. 2018, 149, 59-69. [CrossRef]

125. Zha, L.; Liu, W.; Zhang, Y.; Zhou, C.; Shao, M. Morphological and physiological stress responses of lettuce to different intensities of continuous light. Front. Plant Sci. 2019, 6, 1440. [CrossRef]

126. Tohge, T.; Fernie, A.R. Leveraging natural variance towards enhanced understanding of phytochemical sunscreens. Trends Plant Sci. 2017, 22, 308-315. [CrossRef]

127. Urban, L.; Charles, F.; de Miranda, M.R.A.; Aarrouf, J. Understanding the physiological effects of UV-C light and exploiting its agronomic potential before and after harvest. Plant Physiol. Biochem. 2016, 105, 1-11. [CrossRef]

128. González-Villagra, J.; Marjorie, R.-D.; Alberdi, M.; Acevedo, P.; Loyola, R.; Tighe-Neira, R.; Arce-Johnsona, P.; Inostroza-Blancheteaua, C. Solar UV irradiation effects on photosynthetic performance, biochemical markers, and gene expression in highbush blueberry (Vaccinium corymbosum L.) cultivars. Sci. Hortic. 2020, 259, 108816. [CrossRef]

129. Tripathi, D.K.; Singh, S.; Singh, V.P.; Prasad, S.M.; Dubey, N.K.; Chauhan, D.K. Silicon nanoparticles more effectively alleviated UV-B stress than silicon in wheat (Triticum aestivum) seedlings. Plant Physiol. Biochem. 2017, 110, 70-81. [CrossRef]

130. Yang, L.; Gao, N.; Yang, Y.; Zhang, Y.; Gao, J.; Sun, Y. ABA alleviated soybean seedling stress exposed to UV-C radiation. Int. Agrophys. 2020, 34, 115-121. [CrossRef]

131. Li, H.; Li, D.; Yang, Z.; Zeng, Q.; Luo, Y.; He, N. Flavones produced by mulberry flavone synthase type I constitute a defense line against the ultraviolet-B stress. Plants 2020, 9, 215. [CrossRef] [PubMed]

132. Tiwari, S.; Agrawal, M. Effect of Ozone on Physiological and Biochemical Processes of Plants. In Tropospheric Ozone and its Impacts on Crop Plants, 1st ed.; Tiwari, S., Agrawal, M., Eds.; Springer: New York, NY, USA, 2018; pp. 65-113.

133. Vaultier, M.N.; Jolivet, Y. Ozone sensing and early signaling in plants: An outline from the cloud. Environ. Exp. Bot. 2015, 114, 144-152. [CrossRef]

134. Apel, K.; Hirt, H. Reactive oxygen species: Metabolism, oxidative stress, and signal transduction. Annu. Rev. Plant Biol. 2004, 55, 373-399. [CrossRef] [PubMed]

135. Martins, S.C.V.; Arau'jo, W.L.; Tohge, T.; Fernie, A.R.; DaMatta, F.M. In high-light-acclimated coffee plants the metabolic machinery is adjusted to avoid oxidative stress rather than to benefit from extra light enhancement in photosynthetic yield. PLoS ONE 2014, 9, e94862. [CrossRef] [PubMed]

136. Calzone, A.; Podda, A.; Lorenzini, G.; Maserti, B.E.; Carrari, E.; Deleanu, E.; Hoshika, Y.; Haworth, M.; Nali, C.; Badea, O.; et al. Cross-talk between physiological and biochemical adjustments by Punica granatum cv. Dente di cavallo mitigates the effects of salinity and ozone stress. Sci. Total Environ. 2019, 656, 589-597. [CrossRef] [PubMed]

137. Dolker, T.; Agrawal, M. Negative impacts of elevated ozone on dominant species of semi-natural grassland vegetation in Indo-Gangetic plain. Ecotoxicol. Environ. Saf. 2019, 182, 109404. [CrossRef]

138. Ghosh, A.; Agrawal, M.; Agrawal, S.B. Effect of water deficit stress on an Indian wheat cultivar (Triticum aestivum L. HD 2967), under ambient and elevated level of ozone. Sci. Total Environ. 2020, 714, 136837. [CrossRef]

139. Lee, J.K.; Woo, S.Y.; Kwak, M.J.; Park, S.H.; Kim, H.D.; Lim, Y.J.; Lee, K.A. Effects of elevated temperature and ozone in Brassica juncea L.: Growth, physiology, and ROS accumulation. Forests 2020, 11, 68. [CrossRef]

140. Karnosky, D.; Percy, K.E.; Chappelka, A.H.; Simpson, C.; Pikkarainen, J. Air Pollution, Global Change and Forests in the New Millennium; Develepments in Environmental Science Series; Elsevier: Oxford, UK, 2003.

141. Paoletti, E.; Grulke, N.E. Does living in elevated $\mathrm{CO}_{2}$ ameliorate tree response to ozone? A review on stomatal responses. Environ. Pollut. 2005, 137, 483-493. [CrossRef] [PubMed] 
142. Hoshika, Y.; Katata, G.; Deushi, M.; Watanabe, M.; Koike, T.; Paoletti, E. Ozone-induced stomatal sluggishness changes carbon and water balance of temperate decidGenkiKatata, Makoto Deushi, Makoto Watanabe, Takayoshi Koike \& Elena Paolettiuous forests. Sci. Rep. 2015, 5, 09871.

143. Bhuyan, M.H.M.B.; Hasanuzzaman, M.; Nahar, K.; Mahmud, J.A.; Parvin, K.; Bhuiyan, T.F.; Fujita, M. Plants behavior under soil acidity stress: Insight into morphophysiological, biochemical, and molecular responses. In Plant Abiotic Stress Tolerance; Hasanuzzaman, M., Hakeem, K., Nahar, K., Alharby, H., Eds.; Springer: Cham, Switzerland, 2019; pp. 35-82.

144. Bhuyan, M.H.M.B.; Hasanuzzaman, M.; Mahmud, J.A.; Hossain, M.S.; Alam, M.U.; Fujita, M. Explicating physiological and biochemical responses of wheat cultivars under acidity stress: Insight into the antioxidant defense and glyoxalase systems. Physiol. Mol. Biol. Plants 2019, 25, 865-879. [CrossRef] [PubMed]

145. Liu, D.; Liu, M.; Liu, X.L.; Cheng, X.G.; Liang, Z.W. Silicon priming created an enhanced tolerance in alfalfa (Medicago sativa L.) seedlings in response to high alkaline stress. Front. Plant Sci. 2018, 9, 716. [CrossRef] [PubMed]

146. Bhuyan, M.H.M.B.; Hasanuzzaman, M.; Mahmud, J.A.; Hossain, M.; Bhuiyan, T.F.; Fujita, M. Unraveling morphophysiological and biochemical responses of Triticum aestivum L. to extreme $\mathrm{pH}$ : Coordinated actions of antioxidant defense and glyoxalase systems. Plants 2019, 8, 24. [CrossRef] [PubMed]

147. Bian, M.; Zhou, M.; Sun, D.; Li, C. Molecular approaches unravel the mechanism of acid soil tolerance in plants. Crop J. 2013, 1, 91-104. [CrossRef]

148. Kochian, L.V.; Piñeros, M.A.; Liu, J.; Magalhães, J.V. Plant adaptation to acid soils: The molecular basis for crop aluminum resistance. Annu. Rev. Plant Biol. 2015, 66, 571-598. [CrossRef]

149. Clark, R.B.; Baligar, V.C. Acidic and alkaline soil constraints on plant mineral nutrition. In Plant-Environment Interactions, 2nd ed.; Wilkinson, R.E., Ed.; Marcel Dekker, Inc.: New York, NY, USA, 2000; pp. 133-177.

150. Yu, Q.; Rengel, Z. Micronutrient deficiency influences plant growth and activities of superoxide dismutases in narrow-leafed lupins. Ann. Bot. 1999, 83, 175-182. [CrossRef]

151. Molassiotis, A.; Sotiropoulos, T.; Tanou, G.; Diamantidis, G.; Therios, I. Boron-induced oxidative damage and antioxidant and nucleolytic responses in shoot tips culture of the apple rootstock EM 9 (Malus domestica Borkh). Environ. Exp. Bot. 2006, 56, 54-62. [CrossRef]

152. Tewari, R.K.; Kumar, P.; Sharma, P.N. Magnesium deficiency induced oxidative stress and antioxidant responses in mulberry plants. Sci. Hortic. 2006, 108, 7-14. [CrossRef]

153. Tewari, R.K.; Kumar, P.; Sharma, P.N. Oxidative stress and antioxidant responses in young leaves of mulberry plants grown under nitrogen, phosphorus or potassium deficiency. J. Integr. Plant Biol. 2007, 49, 313-322. [CrossRef]

154. Sun, B.; Jing, Y.; Chen, K.; Song, L.; Chen, F.; Zhang, L. Protective effect of nitric oxide on iron deficiency-induced oxidative stress in maize (Zea mays). J. Plant Physiol. 2007, 164, 536-543. [CrossRef] [PubMed]

155. Pereira, L.B.; Mazzanti, C.M.D.A.; Gonçalves, J.F.; Cargnelutti, D.; Tabaldi, L.A.; Becker, A.G.; Calgaroto, N.S.; Farias, J.G.; Battisti, V.; Bohrer, D.; et al. Aluminum-induced oxidative stress in cucumber. Plant Physiol. Biochem. 2010, 48, 683-689. [CrossRef]

156. Mazid, M.; Saima, Q.; Khan, T.A.; Mohammad, F. Significance of sulphur nutrition against metal induced oxidative stress in plants. J. Stress Physiol. Biochem. 2011, 7, 165-184.

157. Ahmad, P.; Ashraf, M.; Hakeem, K.R.; Azooz, M.M.; Rasool, S.; Chandna, R.; Akram, N.A. Potassium starvation-induced oxidative stress and antioxidant defense responses in Brassica juncea. J. Plant Interact. 2014, 9, 1-9. [CrossRef]

158. Long, A.; Zhang, J.; Yang, L.T.; Ye, X.; Lai, N.W.; Tan, L.L.; Lin, D.; Chen, L.S. Effects of ow pH on photosynthesis, related physiological parameters, and nutrient profiles of Citrus. Front. Plant Sci. 2017, 8, 185. [CrossRef]

159. Shavrukov, Y.; Hirai, Y. Good and bad protons: Genetic aspects of acidity stress responses in plants. J. Exp. Bot. 2015, 67, 15-30. [CrossRef]

160. Wilkinson, R.E.; Duncan, R.R. Sorghum seedling growth as influenced by $\mathrm{H}^{+}, \mathrm{Ca}^{2+}$, and $\mathrm{Mn}^{2+}$ concentrations. J. Plant Nutr. 1989, 12, 1379-1394. [CrossRef]

161. Yang, C.W.; Wang, P.; Li, C.Y.; Shi, D.C.; Wang, D.L. Comparison of effects of salt and alkali stresses on the growth and photosynthesis of wheat. Photosynthetica 2008, 46, 107-114. [CrossRef]

162. Spormann, S.; Soares, C.; Fidalgo, F. Salicylic acid alleviates glyphosate-induced oxidative stress in Hordeum vulgare L. J. Environ. Manag. 2019, 241, 226-234. [CrossRef] [PubMed] 
163. Liu, X.; Qi, C.; Wang, Z.; Li, Y.; Wang, Q.; Guo, M.; Cao, A. Effect of picloram herbicide on physiological responses of Eupatorium adenophorum Spreng. Chil. J. Agric. Res. 2014, 74, 438-444. [CrossRef]

164. Hasanuzzaman, M.; Nahar, K.; Alam, M.M.; Bhuyan, M.H.M.B.; Oku, H.; Fujita, M. Exogenous nitric oxide pretreatment protects Brassica napus L. seedlings from paraquat toxicity through the modulation of antioxidant defense and glyoxalase systems. Plant Physiol. Biochem. 2018, 126, 173-186. [CrossRef] [PubMed]

165. Pazmiño, D.M.; Rodríguez-Serrano, M.; Romero-Puertas, M.C.; Archilla-Ruiz, A.; Del Río, L.A.; Sandalio, L.M. Differential response of young and adult leaves to herbicide 2,4-dichlorophenoxyacetic acid in pea plants: Role of reactive oxygen species. Plant Cell Environ. 2011, 34, 1874-1889. [CrossRef] [PubMed]

166. Xu, L.; Zhang, W.; Ali, B.; Islam, F.; Zhu, J.; Zhou, W. Synergism of herbicide toxicity by 5-aminolevulinic acid is related to physiological and ultra-structural disorders in crickweed (Malachium aquaticum L.). Pestic Biochem Physiol. 2015, 125, 53-61. [CrossRef]

167. Alves, C.; Costa, E.; Sofiatti, J.R.; Forte, C.T.; Winter, F.L.; Holz, C.M.; Kaizer, R.R.; Galon, L. Effect of herbicides in the oxidative stress in crop winter species. An. Acad. Bras. Ciênc. 2018, 90, 1533-1542. [CrossRef]

168. Agostinetto, D.; Perboni, L.T.; Langaro, A.C.; Gomes, J.; Fraga, D.S.; Franco, J.J. Changes in photosynthesis and oxidative stress in wheat plants submmited to herbicides application. Planta Daninha 2016, 34, 1-9. [CrossRef]

169. Langaro, A.C.; Agostinetto, D.; Ruchel, Q.; Garcia, J.R.; Perboni, L.T. Oxidative stress caused by the use of preemergent herbicides in rice crops. Rev. Ciênc. Agron. 2017, 48, 358-364. [CrossRef]

170. Hamim, H.; Violita, V.; Triadiati, T.; Miftahudin, M. Oxidative stress and photosynthesis reduction of cultivated (Glycine max L.) and wild soybean (G. tomentella L.) exposed to drought and paraquat. Asian J. Plant Sci. 2017, 16, 65-77. [CrossRef]

171. Mohammadi, M.H.S.; Etemadi, N.; Arab, M.M.; Aalifar, M.; Arab, M.; Pessarakli, M. Molecular and physiological responses of Iranian Perennial ryegrass as affected by trinexapac ethyl, paclobutrazol and abscisic acid under drought stress. Plant. Physiol. Biochem. 2017, 111, 129-143. [CrossRef]

172. Wang, L.; Feng, C.; Zheng, X.; Guo, Y.; Zhou, F.; Shan, D.; Liu, X.; Kong, J. Plant mitochondria synthesize melatonin and enhance the tolerance of plants to drought stress. J. Pineal Res. 2017, 63, e12429. [CrossRef]

173. Akram, N.A.; Iqbal, M.; Muhammad, A.; Ashraf, M.; Al-Qurainy, F.; Shafiq, S. Aminolevulinic acid and nitric oxide regulate oxidative defense and secondary metabolisms in canola (Brassica napus L.) under drought stress. Protoplasma 2018, 255, 163-174. [CrossRef] [PubMed]

174. Dias, M.C.; Correia, S.; Serôdio, J.; Silva, A.M.S.; Freitas, H.; Santos, C. Chlorophyll fluorescence and oxidative stress endpoints to discriminate olive cultivars tolerance to drought and heat episodes. Sci. Hortic. 2018, 231, 31-35. [CrossRef]

175. Hossain, M.S.; Hasanuzzaman, M.; Sohag, M.M.; Bhuyan, M.H.M.B.; Fujita, M. Acetate-induced modulation of ascorbate: Glutathione cycle and restriction of sodium accumulation in shoot confer salt tolerance in Lens culinaris Medik. Physiol. Mol. Biol. Plants 2019, 25, 443-455. [CrossRef] [PubMed]

176. Mishra, B.; Chand, S.; Sangwan, N.S. ROS management is mediated by ascorbate-glutathione- $\alpha$-tocopherol triad in co-ordination with secondary metabolic pathway under cadmium stress in Withania somnifera. Plant. Physiol. Biochem. 2019, 139, 620-629. [CrossRef]

177. Bhuyan, M.H.M.B.; Parvin, K.; Mohsin, S.M.; Mahmud, J.A.; Hasanuzzaman, M.; Fujita, M. Modulation of cadmium tolerance in rice: Insight into vanillic acid-induced upregulation of antioxidant defense and glyoxalase systems. Plants 2020, 9, 188. [CrossRef]

178. Cao, Y.Y.; Qi, C.D.; Li, S.; Wang, Z.; Wang, X.; Wang, J.; Ren, S.; Li, X.; Zhang, N.; Guo, Y.D. Melatonin alleviates copper toxicity via improving copper sequestration and ROS scavenging in cucumber. Plant Cell Physiol. 2019, 60, 562-574. [CrossRef]

179. Sekmen, A.H.; Ozgur, R.; Uzilday, B.; Turkan, I. Reactive oxygen species scavenging capacities of cotton (Gossypium hirsutum) cultivars under combined drought and heat induced oxidative stress. Environ. Exp. Bot. 2014, 99, 141-149. [CrossRef]

180. Ding, X.; Jiang, Y.; He, L.; Zhou, Q.; Yu, J.; Hui, D.; Huang, D. Exogenous glutathione improves high root-zone temperature tolerance by modulating photosynthesis, antioxidant and osmolytes systems in cucumber seedlings. Sci. Rep. 2016, 18, 35424. [CrossRef]

181. Malerba, M.; Cerana, R. Effect of selenium on the responses induced by heat stress in plant cell cultures. Plants (Basel) 2018, 7, 64. [CrossRef] 
182. Pakkish, Z.; Tabatabaienia, M.S. The use and mechanism of NO to prevent frost damage to flower of apricot. Sci. Hortic. 2016, 198, 318-325. [CrossRef]

183. Xiao, Y.; Wu, X.; Sun, M.; Peng, F. Hydrogen sulfide alleviates waterlogging-induced damage in Peach seedlings via enhancing antioxidative system and inhibiting ethylene synthesis. Front. Plant Sci. 2020, 11, 696. [CrossRef] [PubMed]

184. da-Silva, C.J.; do Amarante, L. Short-term nitrate supply decreases fermentation and oxidative stress caused by waterlogging in soybean plants. Environ. Exp. Bot. 2020, 176, 104078. [CrossRef]

185. Jia, L.; Qin, X.; Lyu, D.; Qin, S.; Zhang, P. ROS production and scavenging in three cherry rootstocks under short-term waterlogging conditions. Sci. Hortic. 2019, 257, 108647. [CrossRef]

186. Qi, X.; Li, Q.; Ma, X.; Qian, C.; Wang, H.; Ren, N.; Shen, C.; Huang, S.; Xu, X.; Xu, Q.; et al. Waterlogging-induced adventitious root formation in cucumber is regulated by ethylene and auxin through reactive oxygen species signalling. Plant Cell Environ. 2019, 42, 1458-1470. [CrossRef] [PubMed]

187. Ramel, F.; Ksas, B.; Akkari, E.; Mialoundama, A.S.; Monnet, F.; Krieger-Liszkay, A.; Ravanat, J.L.; Mueller, M.J.; Bouvier, F.; Havaux, M. Light-induced acclimation of the Arabidopsis chlorina1 mutant to singlet oxygen. Plant Cell 2013, 25, 1445-1462. [CrossRef] [PubMed]

188. Shen, W.; Chen, G.; Xu, J.; Zhen, X.; Ma, J.; Zhang, X.; Lv, C.; Gao, Z. High light acclimation of Oryza sativa L. leaves involves specific photosynthetic-sourced changes of NADPH/NADP ${ }^{+}$in the midvein. Protoplasma 2015, 252, 77-87. [CrossRef] [PubMed]

189. Lu, T.; Meng, Z.; Zhang, G.; Qi, M.; Sun, Z.; Liu, Y.; Li, T. Sub-high temperature and high light intensity induced irreversible inhibition on photosynthesis system of tomato plant (Solanum lycopersicum L.). Front. Plant Sci. 2017, 8, 365. [CrossRef]

190. Dias, M.C.; Pinto, D.C.G.A.; Freitas, H.; Santos, C.; Silva, A.M.S. The antioxidant system in Olea europaea to enhanced UV-B radiation also depends on flavonoids and secoiridoids. Phytochemistry 2020, 170, 112199. [CrossRef]

191. Bulbovas, P.; Souza, S.R.; Esposito, J.B.N.; Moraes, R.M.; Alves, E.S.; Domingos, M.; Azevedo, R.A.D. Assessment of the ozone tolerance of two soybean cultivars (Glycine max cv. Sambaíba and Tracajá) cultivated in Amazonian areas. Environ. Sci. Pollut. Res. 2014, 21, 10514-10524. [CrossRef]

192. Kumari, S.; Agrawal, M.; Singh, A.K. Effects of ambient and elevated $\mathrm{CO}_{2}$ and ozone on physiological characteristics, antioxidative defense system and metabolites of potato in relation to ozone flux. Environ. Exp. Bot. 2015, 109, 276-287. [CrossRef]

193. Dai, L.; Feng, Z.; Pan, X.; Xu, Y.; Li, P.; Lefohn, A.S.; Kobayashi, K. Increase of apoplastic ascorbate induced by ozone is insufficient to remove the negative effects in tobacco, soybean and poplar. Environ. Pollut. 2019, 245, 380-388. [CrossRef] [PubMed]

194. Anusaraporn, S.; Autarmat, S.; Treesubsuntorn, C.; Thiravetyan, P. Application Bacillus sp. N7 to enhance ozone tolerance of various Oryza sativa in vegetative phase: Possible mechanism and rice productivity. Biocatal. Agric. Biotechnol. 2020, 101591. [CrossRef]

195. Pandey, A.K.; Ghosh, A.; Agrawal, M.; Agrawal, S.B. Effect of elevated ozone and varying levels of soil nitrogen in two wheat (Triticum aestivum L.) cultivars: Growth, gas-exchange, antioxidant status, grain yield and quality. Ecotoxicol. Environ. Saf. 2018, 158, 59-68. [CrossRef] [PubMed]

196. Ju, S.; Yin, N.; Wang, L.; Zhang, C.; Wang, Y. Effects of silicon on Oryza sativa L. seedling roots under simulated acid rain stress. PLoS ONE 2017, 12, e0173378. [CrossRef]

197. Debnath, B.; Hussain, M.; Irshad, M.; Mitra, S.; Li, M.; Liu, S.; Qiu, D. Exogenous melatonin mitigates acid rain stress to tomato plants through modulation of leaf ultrastructure, photosynthesis and antioxidant potential. Molecules 2018, 23, 388. [CrossRef]

198. Mir, M.A.; John, R.; Alyemeni, M.N.; Alam, P.; Ahmad, P. Jasmonic acid ameliorates alkaline stress by improving growth performance, ascorbate glutathione cycle and glyoxalase system in maize seedlings. Sci. Rep. 2018, 8, 28-31. [CrossRef]

199. Montesinos-Pereira, D.; de la Torre-González, A.; Blasco, B.; Ruiz, J.M. Hydrogen sulphide increase the tolerance to alkalinity stress in cabbage plants (Brassica oleracea L.'Bronco'). Sci. Hortic. 2018, 235, 349-356. [CrossRef]

200. Ren, X.; Zhu, J.; Liu, H.; Xu, X.; Liang, C. Response of antioxidative system in rice (Oryza sativa) leaves to simulated acid rain stress. Ecotoxicol. Environ. Saf. 2018, 148, 851-856. [CrossRef] 
201. Liu, N.; Zhong, G.; Zhou, J.; Liu, Y.; Pang, Y.; Cai, H.; Wu, Z. Separate and combined effects of glyphosate and copper on growth and antioxidative enzymes in Salvinia natans (L.) All. Sci. Total Environ. 2019, 655, 1448-1456. [CrossRef]

202. Yoon, J.Y.; Shin, J.S.; Shin, D.; Hyun, K.H.; Burgos, N.; Lee, S.; Kuk, Y. Tolerance to paraquat-mediated oxidative and environmental stresses in squash (Cucurbita spp.) leaves of various ages. Pestic. Biochem. Physiol. 2011, 99, 65-76. [CrossRef]

203. Kaya, A.; Doğanlar, Z.B. Exogenous jasmonic acid induces stress tolerance in tobacco (Nicotiana tabacum) exposed to imazapic. Ecotoxicol. Environ. Saf. 2016, 124, 470-479. [CrossRef] [PubMed]

204. Carocho, M.; Ferreira, I.C. A review on antioxidants, prooxidants and related controversy: Natural and synthetic compounds, screening and analysis methodologies and future perspectives. Food Chem. Toxicol. 2013, 51, 15-25. [CrossRef] [PubMed]

205. Berni, R.; Luyckx, M.; Xu, X.; Legay, S.; Sergeant, K.; Hausman, J.F.; Lutts, S.; Cai, G.; Guerriero, G. Reactive oxygen species and heavy metal stress in plants: Impact on the cell wall and secondary metabolism. Environ. Exp. Bot. 2019, 161, 98-106. [CrossRef]

206. Akram, N.A.; Shafiq, F.; Ashraf, M. Ascorbic acid-a potential oxidant scavenger and its role in plant development and abiotic stress tolerance. Front. Plant Sci. 2017, 8, 613. [CrossRef] [PubMed]

207. Naz, H.; Akram, N.A.; Ashraf, M. Impact of ascorbic acid on growth and some physiological attributes of cucumber (Cucumis sativus) plants under water-deficit conditions. Pak. J. Bot. 2016, 48, 877-883.

208. Seminario, A.; Song, L.; Zulet, A.; Nguyen, H.T.; González, E.M.; Larrainzar, E. Drought stress causes a reduction in the biosynthesis of ascorbic acid in soybean plants. Front. Plant Sci. 2017, 8, 1042. [CrossRef]

209. Alam, M.M.; Nahar, K.; Hasanuzzaman, M.; Fujita, M. Alleviation of osmotic stress in Brassica napus, B. campestris, and B. juncea by ascorbic acid application. Biol. Plant. 2014, 58, 697-708. [CrossRef]

210. Latif, M.; Akram, N.A.; Ashraf, M. Regulation of some biochemical attributes in drought-stressed cauliflower (Brassica oleracea L.) by seed pre-treatment with ascorbic acid. J. Hort. Sci. Biotechnol. 2016, 91, 129-137. [CrossRef]

211. Singh, N.; Bhardwaj, R.D. Ascorbic acid alleviates water deficit induced growth inhibition in wheat seedlings by modulating levels of endogenous antioxidants. Biologia 2016, 71, 402-413. [CrossRef]

212. Shafiq, S.; Akram, N.A.; Ashraf, M.; Arshad, A. Synergistic effects of drought and ascorbic acid on growth, mineral nutrients and oxidative defense system in canola (Brassica napus L.) plants. Acta Physiol. Plant. 2014, 36, 1539-1553. [CrossRef]

213. Qados, A.M.S. Effect of Ascorbic Acid antioxidant on Soybean (Glycine max L.) plants grown under water stress conditions. Int. J. Advan. Res. Biol Sci. 2014, 1, 189-205.

214. Razaji, A.; Farzanian, M.; Sayfzadeh, S. The effects of seed priming by ascorbic acid on some morphological and biochemical aspects of rapeseed (Brassica napus L.) under drought stress condition. Int. J. Biosci. 2014, 1, 432-442.

215. Zonouri, M.; Javadi, T.; Ghaderi, N.; Saba, M.K. Effect of foliar spraying of ascorbic acid on chlorophyll a, chlorophyll b, total chlorophyll, carotenoids, hydrogen peroxide, leaf temperature and leaf relative water content under drought stress in grapes. Bull. Environ. Pharmacol. Life Sci. 2014, 3, 178-184.

216. Gong, B.; Sun, S.; Yan, Y.; Jing, X.; Shi, Q. Glutathione metabolism and its function in higher plants adapting to stress. In Antioxidant Enzymes in Higher Plants; Gupta, D., Palma, J., Corpas, F., Eds.; Springer: Cham, Switzerland, 2018; pp. 181-205.

217. Mehla, N.; Sindhi, V.; Josula, D.; Bisht, P.; Wani, S.H. An introduction to antioxidants and their roles in plant stress tolerance. In Reactive Oxygen Species and Antioxidant Systems in Plants: Role and Regulation under Abiotic Stress; Khan, M.I.R., Khan, N.A., Eds.; Springer: Singapore, 2017; pp. 1-23.

218. Singh, S.; Tripathi, D.K.; Chauhan, D.K.; Dubey, N.K. Glutathione and phytochelatins mediated redox homeostasis and stress signal transduction in plants: An integrated overview. In Plant Metal Interaction; Elsevier: Amsterdam, The Netherlands, 2016; pp. 285-310.

219. Hasanuzzaman, M.; Alam, M.; Rahman, A.; Hasanuzzaman, M.; Nahar, K.; Fujita, M. Exogenous proline and glycine betaine mediated upregulation of antioxidant defense and glyoxalase systems provides better protection against salt-induced oxidative stress in two rice (Oryza sativa L.) varieties. BioMed Res. Int. 2014, 2014, 757219. [CrossRef] 
220. García-Caparrós, P.; Hasanuzzaman, M.; Lao, M.T. Oxidative stress and antioxidant defense in plants under salinity. In Reactive Oxygen, Nitrogen and Sulfur Species in Plants: Production, Metabolism, Signaling and Defense Mechanisms; Hasanuzzaman, M., Fotopoulos, V., Nahar, K., Fujita, M., Eds.; John Wiley Sons: Hoboken, NJ, USA, 2019; pp. 291-309.

221. Hussain, S.; Rao, M.J.; Anjum, M.A.; Ejaz, S.; Zakir, I.; Ali, M.A.; Ahmad, N.; Ahmad, S. Oxidative stress and antioxidant defense in plants under drought conditions. In Plant Abiotic Stress Tolerance; Hasanuzzaman, M., Rehman, K., Hakeem, N.K., Alharby, H.F., Eds.; Springer: Cham, Switzerland, 2019; pp. 207-219.

222. Young, A.J.; Lowe, G.L. Carotenoids-Antioxidant properties. Antioxidants 2018, 7, 28. [CrossRef]

223. Liu, S.; Ju, J.; Xia, G. Identification of the flavonoid $3^{\prime}$-hydroxylase and flavonoid $3^{\prime}$, 5' ${ }^{\prime}$-hydroxylase genes from Antarctic moss and their regulation during abiotic stress. Gene 2014, 543, 145-152. [CrossRef]

224. Løvdal, T.; Olsen, K.M.; Slimestad, R.; Verheul, M.; Lillo, C. Synergetic effects of nitrogen depletion, temperature, and light on the content of phenolic compounds and gene expression in leaves of tomato. Phytochemistry 2010, 71, 605-613. [CrossRef]

225. Sisa, M.; Bonnet, S.L.; Ferreira, D.; Van der Westhuizen, J.H. Photochemistry of flavonoids. Molecules 2010, 15, 5196-5245. [CrossRef]

226. Gill, S.S.; Anjum, N.A.; Gill, R.; Yadav, S.; Hasanuzzaman, M.; Fujita, M.; Mishra, P.; Sabat, S.C.; Tuteja, N. Superoxide dismutase-Mentor of abiotic stress tolerance in crop plants. Environ. Sci. Pollut. Res. 2015, 22, 10375-10394. [CrossRef]

227. Das, K.; Roychoudhury, A. Reactive oxygen species (ROS) and response of antioxidants as ROS-scavengers during environmental stress in plants. Front. Environ. Sci. 2014, 2, 53. [CrossRef]

228. Sofo, A.; Scopa, A.; Nuzzaci, M.; Vitti, A. Ascorbate Peroxidase and Catalase Activities and Their Genetic Regulation in Plants Subjected to Drought and Salinity Stresses. Int. J. Mol. Sci. 2015, 16, 13561-13578. [CrossRef] [PubMed]

229. Martínez-Rubio, R.; Acebes, J.L.; Encina, A.; Kärkönen, A. Class III peroxidases in cellulose deficient cultured maize cells during cell wall remodeling. Physiol. Plant. 2018, 164, 45-55. [CrossRef] [PubMed]

230. Leterrier, M.; Cagnac, O. Function of the various MDAR isoforms in higher plants. In Antioxidants and Antioxidant Enzymes in Higher Plants; Gupta, D., Palma, J., Corpas, F., Eds.; Springer: Cham, Switzerland, 2018; pp. 83-94.

231. Yildizli, A.; Çevik, S.; Ünyayar, S. Effects of exogenous myo-inositol on leaf water status and oxidative stress of Capsicum annuum under drought stress. Acta Physiol. Plant. 2018, 40, 122. [CrossRef]

232. Nianiou-Obeidat, I.; Madesis, P.; Kissoudis, C.; Voulgari, G.; Chronopoulou, E.; Tsaftaris, A.; Labrou, N.E. Plant glutathione transferase-mediated stress tolerance: Functions and biotechnological applications. Plant Cell Rep. 2017, 36, 791-805. [CrossRef]

233. Nahar, K.; Hasanuzzaman, M.; Rahman, A.; Alam, M.; Mahmud, J.A.; Suzuki, T.; Fujita, M. Polyamines confer salt tolerance in mung bean (Vigna radiata $\mathrm{L}$.) by reducing sodium uptake, improving nutrient homeostasis, antioxidant defense, and methylglyoxal detoxification systems. Front. Plant. Sci. 2016, 7, 1104. [CrossRef]

234. Sahoo, D.P.; Kumar, S.; Mishra, S.; Kobayashi, Y.; Panda, S.K.; Sahoo, L. Enhanced salinity tolerance in transgenic mungbean overexpressing Arabidopsis antiporter (NHX1) gene. Mol. Breed. 2016, 36, 144. [CrossRef]

235. Sarkar, J.; Bishwanath, C.; Usha, C. Temperature stress induced antioxidative and biochemical changes in wheat (Triticum aestivum L.) cultivars. J. Plant Stress Physiol. 2016, 2, 22. [CrossRef]

236. Ji, C.Y.; Jin, R.; Xu, Z.; Kim, H.S.; Lee, C.J.; Kang, L.; Kim, S.E.; Lee, H.U.; Lee, J.S.; Kang, C.H.; et al. Overexpression of Arabidopsis $\mathrm{P} 3 \mathrm{~B}$ increases heat and low temperature stress tolerance in transgenic sweet potato. BMC Plant Biol. 2017, 17, 139. [CrossRef]

237. Karkute, S.G.; Krishna, R.; Ansari, W.A.; Singh, B.; Singh, P.M.; Singh, M.; Singh, A.K. Heterologous expression of the AtDREB1A gene in tomato confers tolerance to chilling stress. Biol. Plant. 2019, 63, 268-277. [CrossRef]

238. Majláth, I.; Éva, C.; Tajti, J.; Khalil, R.; Elsayed, N.; Darko, E.; Szalai, G.; Janda, T. Exogenous methylglyoxal enhances the reactive aldehyde detoxification capability and frost-hardiness of wheat. Plant. Physiol. Biochem. 2020, 149, 5-85. [CrossRef] [PubMed]

239. Kim, Y.; Seo, C.W.; Khan, A.L.; Mun, B.G.; Shahzad, R.; Ko, J.W.; Yun, B.W.; Park, S.K.; Lee, I.J. Exo-ethylene application mitigates waterlogging stress in soybean (Glycine max L.). BMC Plant Biol. 2018, 18, 254. [CrossRef] 
240. Damanik, R.I.; Lumbangaol, L.D.; Rahmawaty, N.; Sipayung, R. Effect of benzyl amino purin (BAP) and gibberellin acid $\left(\mathrm{GA}_{3}\right)$ to chlorophyll and antioxidant enzymes of soybean (Glycine max L. Merill.) genotypes in response to inundation conditions. IOP Conf. Ser. Earth Environ. Sci. 2019, 260, 012153. [CrossRef]

241. Ai, T.N.; Naing, A.H.; Yun, B.-W.; Lim, S.H.; Kim, C.K. Overexpression of RsMYB1 enhances anthocyanin accumulation and heavy metal stress tolerance in transgenic petunia. Front. Plant Sci. 2018, 9, 1388. [CrossRef] [PubMed]

242. Saad, R.B.; Hsouna, A.B.; Saibi, W.; Hamed, K.B.; Brini, F.; Ghneim-Herrera, T. A stress-associated protein, LmSAP, from the halophyte Lobularia maritima provides tolerance to heavy metals in tobacco through increased ROS scavenging and metal detoxification processes. J. Plant. Physiol. 2018, 231, 234-243. [CrossRef] [PubMed]

243. Dursun, K.I.S.A. The responses of antioxidant system against the heavy metal-induced stress in tomato. Süleyman Demirel Üniversitesi Fen Bilimleri Enstitüsü Dergisi 2018, 22, 1-6.

244. Lima-Melo, Y.; Alencar, V.T.C.B.; Lobo, A.K.M.; Sousa, R.H.V.; Tikkanen, M.; Aro, E.M.; Silveira, J.A.G.; Gollan, P.J. Photoinhibition of photosystem I provides oxidative protection during imbalanced photosynthetic electron transport in Arabidopsis thaliana. Front. Plant Sci. 2019, 10, 916. [CrossRef]

245. Czégény, G.; Kőrösi, L.; Strid, Å.; Hideg, É. Multiple roles for vitamin B 6 in plant acclimation to UV-B. Sci. Rep. 2019, 9, 1259. [CrossRef]

246. Qiu, Y.; An, K.; Sun, J.; Chen, X.; Gong, X.; Ma, L.; Wu, S.; Jiang, S.; Zhang, Z.; Wang, Y. Investigating the effect of methyl jasmonate and melatonin on resistance of Malus crabapple 'Hong Jiu' to ozone stress. Environ. Sci. Pollut. Res. 2019, 26, 27761-27768. [CrossRef]

247. Kuk, Y.I.; Shin, J.S.; Jung, H.; Guh, J.O.; Jung, S.; Burgos, N.R. Mechanism of paraquat tolerance in cucumber leaves of various ages. Weed Sci. 2006, 54, 6-15. [CrossRef]

248. Das, P.; Nutan, K.K.; Singla-Pareek, S.L.; Pareek, A. Oxidative environment and redox homeostasis in plants: Dissecting out significant contribution of major cellular organelles. Front. Environ. Sci. 2015, 2, 70. [CrossRef]

249. Palma, F.; Carvajal, F.; Jamilena, M.; Garrido, D. Putrescine treatment increases the antioxidant response and carbohydrate content in zucchini fruit stored at low temperature. Postharvest Biol. Technol. 2016, 118, 68-70. [CrossRef]

250. Hasanuzzaman, M.; Nahar, K.; Hossain, M.S.; Mahmud, J.A.; Rahman, A.; Inafuku, M.; Oku, H.; Fujita, M. Coordinated actions of glyoxalase and antioxidant defense systems in conferring abiotic stress tolerance in plants. Int. J. Mol. Sci. 2017, 18, 200. [CrossRef] [PubMed]

251. Couto, N.; Wood, J.; Barber, J. The role of glutathione reductase and related enzymes on cellular redox homoeostasis network. Free Radic. Biol. Med. 2016, 95, 27-42. [CrossRef] [PubMed]

252. Bela, K.; Horváth, E.; Gallé, Á.; Szabados, L.; Tari, I.; Csiszár, J. Plant glutathione peroxidases: Emerging role of the antioxidant enzymes in plant development and stress responses. J. Plant Physiol. 2015, 176, 192-201. [CrossRef] [PubMed]

253. Koua, D.; Cerutti, L.; Falquet, L.; Sigrist, C.J.; Theiler, G.; Hulo, N.; Dunand, C. PeroxiBase: A database with new tools for peroxidase family classification. Nucleic Acids Res. 2009, 37, 261-266. [CrossRef]

254. Passaia, G.; Margis-Pinheiro, M. Glutathione peroxidases as redox sensor proteins in plant cells. Plant Sci. 2015, 234, 22-26. [CrossRef]

255. Ozyigit, I.I.; Filiz, E.; Vatansever, R.; Kurtoglu, K.Y.; Koc, I.; Öztürk, M.X.; Anjum, N.A. Identification and comparative analysis of $\mathrm{H}_{2} \mathrm{O}_{2}$-scavenging enzymes (ascorbate peroxidase and glutathione peroxidase) in selected plants employing bioinformatics approaches. Front. Plant Sci. 2016, 7, 301. [CrossRef]

256. Dong, Y.; Li, C.; Zhang, Y.; He, Q.; Daud, M.K.; Chen, J.; Zhu, S. Glutathione S-transferase gene family in Gossypium raimondii and G. arboreum: Comparative genomic study and their expression under salt stress. Front. Plant Sci. 2016, 7, 139. [CrossRef]

257. Gallé, Á.; Csiszár, J.; Secenji, M.; Guóth, A.; Cseuz, L.; Tari, I.; Györgyey, J.; Erdei, L. Glutathione transferase activity and expression patterns during grain filling in flag leaves of wheat genotypes differing in drought tolerance: Response to water deficit. J. Plant Physiol. 2009, 166, 1878-1891. [CrossRef]

258. Cicero, L.L.; Madesis, P.; Tsaftaris, A.; Piero, A.R.L. Tobacco plants over-expressing the sweet orange tau glutathione transferases (CsGSTUs) acquire tolerance to the diphenyl ether herbicide fluorodifen and to salt and drought stresses. Phytochem 2015, 116, 69-77. [CrossRef] [PubMed] 
259. Bhuiyan, T.F.; Ahamed, K.U.; Nahar, K.; Al Mahmud, J.; Bhuyan, M.H.M.B.; Anee, T.I.; Fujita, M.; Hasanuzzaman, M. Mitigation of PEG-induced drought stress in rapeseed (Brassica rapa L.) by exogenous application of osmolytes. Biocatal. Agric. Biotechnol. 2019, 20, 101197. [CrossRef]

260. Hassan, N.; Ebeed, H.; Aljaarany, A. Exogenous application of spermine and putrescine mitigate adversities of drought stress in wheat by protecting membranes and chloroplast ultra-structure. Physiol. Mol. Biol. Plant. 2020, 26, 233-245. [CrossRef]

261. Rady, M.M.; Belal, H.E.; Gadallah, F.M.; Semida, W.M. Selenium application in two methods promotes drought tolerance in Solanum lycopersicum plant by inducing the antioxidant defense system. Sci. Hortic. 2020, 266, 109290. [CrossRef]

262. Vighi, I.L.; Benitez, L.C.; Amaral, M.N.; Moraes, G.P.; Auler, P.A.; Rodrigues, G.S.; Braga, E.J.B. Functional characterization of the antioxidant enzymes in rice plants exposed to salinity stress. Biol. Plant. 2017, 61, 540-550. [CrossRef]

263. Chung, Y.S.; Kim, K.S.; Hamayun, M.; Kim, Y. Silicon confers soybean resistance to salinity stress through regulation of reactive oxygen and reactive nitrogen species. Front. Plant Sci. 2019, 10, 1725. [CrossRef] [PubMed]

264. Srivastava, M.; Shahi, S. Effect of salinity on morpho-physiological aspects, antioxidant enzymatic studies and yield attributes in wheat genotypes. Indian J. Plant. Physiol. 2018, 23, 385-392. [CrossRef]

265. Alsahli, A.; Mohamed, A.K.; Alaraidh, I.; Al-Ghamdi, A.; Al-Watban, A.; El-Zaidy, M.; Alzahrani, S.M. Salicylic acid alleviates salinity stress through the modulation of biochemical attributes and some key antioxidants in wheat seedlings. Pak. J. Bot. 2019, 51, 1551-1559. [CrossRef]

266. Rady, M.O.; Semida, W.M.; El-Mageed, T.A.A.; Hemida, K.A.; Rady, M.M. Up-regulation of antioxidative defense systems by glycine betaine foliar application in onion plants confer tolerance to salinity stress. Sci. Hortic. 2018, 240, 614-622. [CrossRef]

267. Hasanuzzaman, M.; Fujita, M. Heavy metals in the environment: Current status, toxic effects on plants and possible phytoremediation. In Phytotechnologies: Remediation of Environmental Contaminants; Anjum, N.A., Pereira, M.A., Ahmed, I., Duarte, A.C., Umar, S., Khan, N.A., Eds.; CRC Press: Boca Raton, FL, USA, 2012; pp. 7-73.

268. Gratão, P.L.; Alves, L.R.; Lima, L.W. Heavy Metal Toxicity and Plant Productivity. In Plant-Metal Interactions: Role of Metal Scavengers; Srivastava, S., Srivastava, A.K., Suprasanna, P., Eds.; Springer Nature: Cham, Switzerland, 2019; pp. 49-60.

269. Mahmud, J.A.; Bhuyan, M.H.M.B.; Anee, T.I.; Nahar, K.; Fujita, M.; Hasanuzzaman, M. Reactive oxygen species metabolism and antioxidant defense in plants under metal/metalloid stress. In Plant Abiotic Stress Tolerance; Hasanuzzaman, M., Hakeem, K.R., Nahar, K., Alharby, H., Eds.; Springer Nature: Cham, Switzerland, 2019; pp. 221-257.

270. Yadu, B.; Chandrakar, V.; Tamboli, R.; Keshavkant, S. Dimethylthiourea antagonizes oxidative responses by up-regulating expressions of pyrroline-5-carboxylate synthetase and antioxidant genes under arsenic stress. Int. J. Environ. Sci. Technol. 2019, 16, 8401-8410. [CrossRef]

271. Parvez, S.; Abbas, G.; Shahid, M.; Amjad, M.; Hussain, M.; Asad, S.A.; Imran, M.; Naeem, M.A. Effect of salinity on physiological, biochemical and photostabilizing attributes of two genotypes of quinoa (Chenopodium quinoa Willd.) exposed to arsenic stress. Ecotoxicol. Environ. Saf. 2020, 187, 109814. [CrossRef] [PubMed]

272. Hasanuzzaman, M.; Nahar, K.; Alam, M.M.; Roychowdhury, R.; Fujita, M. Physiological, biochemical, molecular mechanisms of heat stress tolerance in plants. Int. J. Mol. Sci. 2013, 14, 9643-9684. [CrossRef] [PubMed]

273. Mansoor, S.; Naqvi, F.N. Effect of heat stress on lipid peroxidation and antioxidant enzymes in mung bean (Vigna radiata L.) seedlings. Afr. J. Biotechnol. 2013, 12, 3196-3203.

274. Djanaguiraman, M.; Perumal, R.; Jagadish, S.V.; Ciampitti, I.A.; Welti, R.; Prasad, P.V. Sensitivity of sorghum pollen and pistil to high-temperature stress. Plant Cell Environ. 2018, 41, 1065-1082. [CrossRef] [PubMed]

275. Soengas, P.; Rodríguez, V.M.; Velasco, P.; Cartea, M.E. Effect of temperature stress on antioxidant defenses in Brassica oleracea. ACS Omega 2018, 3, 5237-5243. [CrossRef] [PubMed]

276. Rihan, H.Z.; Al-Issawi, M.; Fuller, M.P. Advances in physiological and molecular aspects of plant cold tolerance. J. Plant Interact. 2017, 12, 143-157. [CrossRef] 
277. Wang, X.; Fang, G.; Li, Y.; Ding, M.; Gong, H.; Li, Y. Differential antioxidant responses to cold stress in cell suspension cultures of two subspecies of rice. Plant Cell Tiss. Organ. Cult. 2013, 113, 353-361. [CrossRef]

278. Shi, H.; Ye, T.; Zhong, B.; Liu, X.; Chan, Z. Comparative proteomic and metabolomic analyses reveal mechanisms of improved cold stress tolerance in bermudagrass (Cynodon dactylon L. Pers.) by exogenous calcium. J. Integr. Plant Biol. 2014, 56, 1064-1079. [CrossRef]

279. Wani, M.A.; Jan, N.; Qazi, H.A.; Andrabi, K.I.; John, R. Cold stress induces biochemical changes, fatty acid profile, antioxidant system and gene expression in Capsella bursa pastoris L. Acta Physiol. Plant. 2018, 40, 167. [CrossRef]

280. Mohammadrezakhani, S.; Hajilou, J.; Rezanejad, F.; Zaare-Nahandi, F. Assessment of exogenous application of proline on antioxidant compounds in three Citrus species under low temperature stress. J. Plant Interact. 2019, 14, 347-358. [CrossRef]

281. Spanò, C.; Bottega, S.; Castiglione, M.R.; Pedranzani, H.E. Antioxidant response to cold stress in two oil plants of the genus Jatropha. Plant Soil Environ. 2017, 63, 271-276.

282. Cheng, F.; Lu, J.; Gao, M.; Shi, K.; Kong, Q.; Huang, Y.; Bie, Z. Redox signaling and CBF-responsive pathway are involved in salicylic acid-improved photosynthesis and growth under chilling stress in watermelon. Front. Plant Sci. 2016, 7, 1519. [CrossRef] [PubMed]

283. Chen, Y.; Tao, J.; Zhao, P.J.; Tang, W.; Xu, J.P.; Zhang, K.Q.; Zou, C.G. Adiponectin receptor PAQR-2 signaling senses low temperature to promote C. elegans longevity by regulating autophagy. Nat. Commun. 2019, 10, 2602. [CrossRef]

284. Rasheed, R.; Iqbal, M.; Ashraf, M.A.; Hussain, I.; Shafiq, F.; Yousaf, A.; Zaheer, A. Glycine betaine counteracts the inhibitory effects of waterlogging on growth, photosynthetic pigments, oxidative defence system, nutrient composition, and fruit quality in tomato. J. Hortic. Sci. Biotechnol. 2017, 93, 385-391. [CrossRef]

285. Anee, T.I.; Nahar, K.; Rahman, A.; Mahmud, J.A.; Bhuiyan, T.F.; Alam, M.U.; Fujita, M.; Hasanuzzaman, M. Oxidative damage and antioxidant defense in Sesamum indicum after different waterlogging durations. Plants 2019, 8, 196. [CrossRef]

286. Seymen, M. How does the flooding stress occurring in different harvest times affect the morpho-physiological and biochemical characteristics of spinach? Sci. Hortic. 2021, 275, 109713. [CrossRef]

287. Men, S.; Chen, H.; Chen, S.; Zheng, S.; Shen, X.; Wang, C.; Yang, Z.; Liu, D. Effects of supplemental nitrogen application on physiological characteristics, dry matter and nitrogen accumulation of winter rapeseed (Brassica napus L.) under waterlogging stress. Sci. Rep. 2020, 10, 1-10. [CrossRef] [PubMed]

288. Zhao, X.; Chen, T.; Feng, B.; Zhang, C.; Peng, S.; Zhang, X.; Fu, G.; Tao, L. Non-photochemical quenching plays a key role in light acclimation of rice plants differing in leaf color. Front. Plant Sci. 2017, 7, 1968. [CrossRef]

289. Gu, J.; Zhou, Z.; Li, Z.; Chen, Y.; Wang, Z.; Zhang, H.; Yang, J. Photosynthetic properties and potentials for improvement of photosynthesis in pale green leaf rice under high light conditions. Front. Plant Sci. 2017, 8, 1082. [CrossRef] [PubMed]

290. Ni, Y.W.; Lin, K.H.; Chen, K.H.; Wu, C.W.; Chang, Y.S. Flavonoid compounds and photosynthesis in passiflora plant leaves under varying light intensities. Plants 2020, 9, 633. [CrossRef]

291. Stewart, J.J.; Adams, W.W., 3rd; Escobar, C.M.; López-Pozo, M.; Demmig-Adams, B. Growth and essential carotenoid micronutrients in Lemna gibba as a function of growth light intensity. Front. Plant Sci. 2020, 11, 480. [CrossRef] [PubMed]

292. Hakala-Yatkin, M.; Mantysaari, M.; Mattila, H.; Tyystjärvi, E. Contributions of visible and ultraviolet parts of sunlight to photoinhibition. Plant Cell Physiol. 2010, 51, 1745-1753. [CrossRef]

293. Demarsy, E.; Goldschmidt-Clermont, M.; Ulm, R. Coping with 'Dark Sides of the Sun' through photoreceptor signaling. Trends Plant Sci. 2018, 23, 260-271. [CrossRef] [PubMed]

294. Wilkinson, S.; Mills, G.; Illidge, R.; Davies, W.J. How is ozone pollution reducing our food supply? J. Exp. Bot. 2012, 63, 527-536. [CrossRef] [PubMed]

295. Lemoine, R.; La Camera, S.; Atanassova, R.; Dédaldéchamp, F.; Allario, T.; Pourtau, N.; Bonnemain, J.L.; Laloi, M.; Coutos-Thévenot, P.; Maurousset, L.; et al. Source-to-sink transport of sugar and regulation by environmental factors. Front. Plant Sci. 2013, 4, 272. [CrossRef] [PubMed]

296. Tammam, A.; Badr, R.; Abou-Zeid, H.; Hassan, Y.; Bader, A. Nickel and ozone stresses induce differential growth, antioxidant activity and mRNA transcription in Oryza sativa cultivars. J. Plant Interact. 2019, 14, 87-101. [CrossRef] 
297. Wang, J.; Liu, G.; Liu, F.; Zhu, J. Responses of antioxidant enzymes to chronic free-air ozone stress in rice (Oryza sativa L.) cultivars with different ozone-sensitivities. Bull. Environ. Contam. Toxicol. 2019, 103, 428-434. [CrossRef]

298. Kamal, M.Z.U.; Yamaguchi, M.; Kinose, Y.; Izuta, T. Mitigation mechanism of ozone-induced reduction in net photosynthesis of Bangladeshi wheat under soil salinity stress. Photosynthetica 2019, 57, 1025-1034. [CrossRef]

299. Délye, C.; Duhoux, A.; Pernin, F.; Riggins, C.W.; Tranel, P.J. Molecular mechanisms of herbicide resistance. Weed Sci. 2015, 63, 91-115. [CrossRef]

300. Benekos, K.; Kissoudis, C.; Nianiou-Obeidat, I.; Labrou, N.; Madesis, P.; Kalamaki, M.; Makris, A.; Tsaftaris, A. Overexpression of a specific soybean GmGSTU4 isoenzyme improves diphenyl ether and chloroacetanilide herbicide tolerance of transgenic tobacco plants. J. Biotechnol. 2010, 150, 195-201. [CrossRef]

Publisher's Note: MDPI stays neutral with regard to jurisdictional claims in published maps and institutional affiliations.

(C) 2020 by the authors. Licensee MDPI, Basel, Switzerland. This article is an open access article distributed under the terms and conditions of the Creative Commons Attribution (CC BY) license (http://creativecommons.org/licenses/by/4.0/). 